UNIVERSIDADE DE SÃO PAULOO

FACULDADE DE EDUCAÇÃO

PSICOLOGIA DA EDUCAÇÃO

DANIELA MOREL FARIAS

ESVAZIAMENTO DA AUTORIDADE DA PALAVRA DO PROFESSOR: UMA REFLEXÃO PSICANALÍTICA SOBRE A CRISE CONTEMPORÂNEA NA EDUCAÇÃO 
DANIELA MOREL FARIAS

ESVAZIAMENTO DA AUTORIDADE DA PALAVRA DO PROFESSOR: UMA REFLEXÃO PSICANALÍTICA SOBRE A CRISE CONTEMPORÂNEA NA EDUCAÇÃO

Dissertação apresentada à Faculdade de Educação da Universidade de São Paulo para obtenção do título de Mestre em Educação

Área de Concentração:

Psicologia e Educação

Orientadora: Profa. Dra.

Leny Magalhães Mrech 
AUTORIZO A REPRODUÇÃO E DIVULGAÇÃO TOTAL OU PARCIAL DESTE TRABALHO, POR QUALQUER MEIO CONVENCIONAL OU ELETRÔNICO, PARA FINS DE ESTUDO E PESQUISA, DESDE QUE CITADA A FONTE.

Catalogação na Publicação

Serviço de Biblioteca e Documentação

Faculdade de Educação da Universidade de São Paulo

$37.046 \quad$ Farias, Daniela Morel

F224e Esvaziamento da autoridade da palavra do professor: uma reflexão psicanalítica sobre a crise contemporânea na educação / Daniela Morel Farias; orientação Leny Magalhães Mrech. São Paulo: s.n., 2015.

161 p.; apêndice

Dissertação (Mestrado - Programa de Pós-Graduação em Educação. Área de Concentração: Psicologia e Educação) - - Faculdade de Educação da Universidade de São Paulo.

1. Psicologia Educacional 2. Autoridade 3.Palavra 4. Educação I. Mrech, Leny Magalhães, orient. 
Nome: FARIAS, Daniela Morel

Título: Esvaziamento da autoridade da palavra do professor: uma reflexão psicanalítica sobre a crise contemporânea na Educação

Dissertação apresentada à Faculdade de Educação da Universidade de São Paulo para obtenção do título de Mestre em Educação

Aprovada em:

Banca Examinadora

Prof. Dr. Instituição:

Julgamento: Assinatura:

Prof. Dr. Instituição:

Julgamento:

Assinatura:

Prof. Dr.

Instituição:

Julgamento: Assinatura:

Prof. Dr. Instituição:

Julgamento: Assinatura:

Prof. Dr. Instituição:

Julgamento: Assinatura: 


\section{AGRADECIMENTOS}

Aos meus amados pais César e Fernanda, por abdicarem de algumas coisas para realizarem as nossas, pelo amor imenso, pelo apoio incondicional e por acreditarem que eu poderia vencer mais essa batalha e com isso me deram forças.

À minha irmã Mariana que me inspira com sua alegria, entusiasmo e amor à família.

Ao Gustavo, meu companheiro, por sua sabedoria e amor.

À toda minha família pelo amor que nos une.

Às minhas avós Silvana e Mariulda que sustentam nossas raízes e nossa história.

À professora Leny Magalhães Mrech por me acolher em um momento delicado e decisivo desta pesquisa. Por acreditar na pesquisadora que existe em mim, por fazer tudo (ou mais) que um orientador deve fazer, conseguindo fazer isso com carinho. E pela imensa dedicação à Educação e à Psicanálise, a mesma que sustenta e inspira minha escrita e minha profissão.

Ao Douglas Emiliano Batista, um exemplo de mestre, por acreditar que eu conseguiria ir em frente, por me ensinar muito sobre Psicanálise e Educação e pela delicadeza com que oferece seus conhecimentos.

A todos do Núcleo de Pesquisa em Psicanálise e Educação (NUPPE) por terem me recebido de braços abertos e me lançado em um estudo rico e profundo da Psicanálise.

Às minhas queridas amigas de infância e de sempre Luciana, Marcela e Marina por oferecerem suas palavras e seu apoio nesse tempo de pesquisa.

Às minhas amadas tias Carmen e Eliana pelo amor que me faz caminhar, pelo compromisso profundo que acontece todos os dias na escola; pela escuta delicada e pelas palavras que me ajudam e me ensinam. 
A todos que trabalham na Ponto de Partida Escola de Educação Infantil, um lugar muito especial onde há pessoas que amam o que fazem e se dedicam muito para construir um ambiente maravilhoso em meio a um mundo difícil.

À Selma Amaral, pela excelente revisão, dedicação e amizade que me resgatou do risco da desistência e me fez acreditar que é possível.

Às amigas que o mestrado me trouxe Samanta, Aline, Elaine, Sâmara e Vanessa por dividirem comigo as angústias, descobertas e conquistas desse longo percurso.

Aos professores entrevistados pela dedicação à Educação e por terem concedido um tempo para responderem nossas perguntas e nos emprestarem suas valiosas palavras.

Aos meus professores do Colégio Rainha da Paz por todo esforço silencioso que fazem na esperança de engancharem suas palavras.

À secretaria de Pós-graduação pela delicadeza e atenção com que nos atendem.

À Coordenação de Aperfeiçoamento de Pessoal de Ensino Superior (CAPES) pela concessão de bolsa de pesquisa. 


\section{RESUMO}

FARIAS, D. M. Esvaziamento da autoridade da palavra do professor: uma reflexão psicanalítica sobre a crise contemporânea na Educação. 2015. 161 f. Dissertação (Mestrado) - Faculdade de Educação, Universidade de São Paulo, São Paulo, 2015.

Esta pesquisa buscou refletir sobre o mal-estar na civilização e a crise na educação como geradores de um possível esvaziamento da autoridade da palavra do professor, permitindo o desdobramento de duas principais perguntas: O esvaziamento da autoridade da palavra poderia afetar o esvaziamento do enigma que permite a aprendizagem? As mudanças na aprendizagem, que às vistas da contemporaneidade parecem ser inevitáveis, podem vir a ser benéficas de alguma forma para os sujeitos contemporâneos? Para responder a essas perguntas, buscamos, na teoria psicanalítica e na área de Psicanálise e Educação, elucidar a crise e o mal-estar ao qual estamos nos referindo e o quanto as mudanças no modo de vida dos sujeitos influencia o discurso que circula na Educação. Para refletir sobre esses pontos, dedicamo-nos a entrevistas semidirecionadas realizadas com oito professores da rede pública municipal de São Paulo com o intuito de analisar em suas falas, possíveis indícios do esvaziamento da autoridade de sua palavra nesse ambiente de crise. Pudemos constatar que o mal-estar na cultura é estrutural e a crise na Educação é somente um dos tentáculos do malestar inerente à condição humana moderna. $\mathrm{O}$ esvaziamento da autoridade da palavra seria, portanto, um "mais-além" da crise, que se manifesta como não sendo estrutural para o sujeito, e sim uma consequência da forma com a qual os sujeitos lidam com a influência dos discursos (técnico-científico e da ciência) que, por sua vez, esvaziam o enigma da palavra, tornando-a "toda", ou seja, o significado passa a estar colado à palavra e ao objeto que a ela faz referência. Buscou-se compreender o quanto o esvaziamento da palavra afeta os professores na sala de aula e também como podemos pensar o esvaziamento deste sentido "todo" da palavra para um sentido "não-todo". Nas entrevistas, pudemos constatar que os professores apontam para um esvaziamento da autoridade de sua palavra, que seria o esvaziamento do peso da palavra do professor no discurso social. Seu direito de falar estaria esvaziando-se, já que não há nada que o sustente no lugar de professor que professa suas palavras. Concluímos que a palavra do professor não engancha mais no aluno. Concluímos também que esvaziar a palavra de seu enigma torna-se nocivo para o professor e para o aluno, porém, esvaziar-se da intenção de capturar um sentido totalizante da palavra pode vir a ser benéfico para os sujeitos da Educação.

Palavras-chave - Psicanálise e Educação. Autoridade. Palavra. Crise na Educação 


\begin{abstract}
FARIAS, D. M. Emptying the teacher's word of authority: a psychoanalytic reflection on the contemporary crisis in Education. 2015. 161 f. Dissertação (Mestrado) - Faculdade de Educação, Universidade de São Paulo, São Paulo, 2015.

The aim of the present study was to reflect on the malaise in civilization and the crisis in education as generators of a possible emptying of the teacher's word of authority. This research allowed to deploy two main questions: is the emptying of the word of authority could affect the emptying of the riddle that allows learning? Do these changes in learning, -that seem to be inevitable to the contemporary view - may turn out to be beneficial in some way to the contemporary subjects? To answer these questions we seek in psychoanalytic theory and in the area of Psychoanalysis and Education in order to elucidate about which crisis and which malaise we are talking about and how the changes in the subjects' way of life influences the discourse that circulates in Education and the teachers. We also dedicated ouselves on semidirected interviews with eight teachers from the city of São Paulo in order to analyze evidences on the emptying of the teacher's word of authority inside this crisis environment. We observed that the malaise in culture is structural and the crisis in education is only one of the tentacles of the malaise and both are inherent in modern human condition. The emptying of the authority of word would therefore be a "beyond" the crisis, which manifests itself as not being structural to the subject, but a consequence of how the subjects deal with the influence of discourses (technical-scientific and science ) that want to empty the riddle of the word, making it "whole", that is, the meaning is henceforth glued to the word and the object that it references. We tried to understand how the word's emptying process affects the teacher in the classroom and also how we could consider this emptying process of the word from a "whole" to a "not whole" way of thinking. In the interviews we found that the teacher points to an deflation of the authority of his word, that would be the emptying of the weight of the teacher's word in social discourse. Their right to speak would be getting emptying, since there is nothing to hold or support the professor's place. Thus, we conclude that the word of the teacher does not hook over the student. We also conclude that empty the word of his riddle becomes harmful to the teacher, however, emptying the intention to capture a totalizing sense of the word may prove to be beneficial to the subjects of Education.
\end{abstract}

Keywords: Psychoanalysis and Education. Authority. Word. Crisis in Education 


\section{SUMÁRIO}

1 INTRODUÇÃ

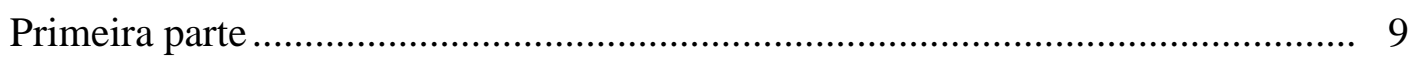

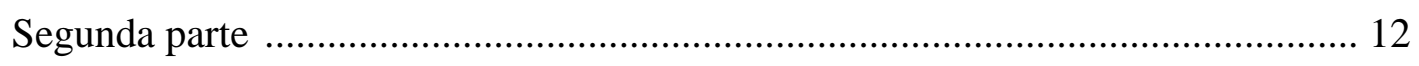

2 POR QUE UTILIZAR A PSICANÁLISE PARA FALAR DE EDUCAÇÃO? 19

3 PANORAMA DA CRISE NA EDUCAÇÃO ..................................................... 23

3.1 O MAL-ESTAR NA CIVILIZAÇÃO COMO ESTRUTURAL …........................ 23

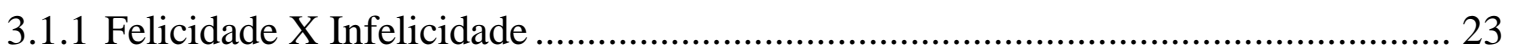

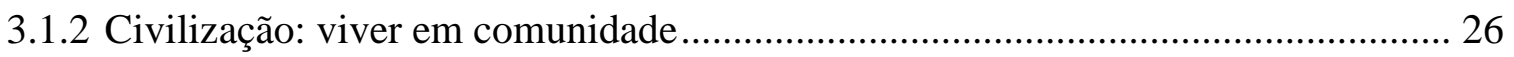

3.1.3 Amor, instinto e sexualidade na civilização...................................................... 28

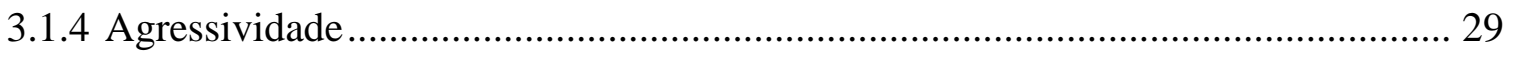

3.2 CRISE NA EDUCAÇÃO À LUZ DO PENSAMENTO DE HANNAH ARENDT

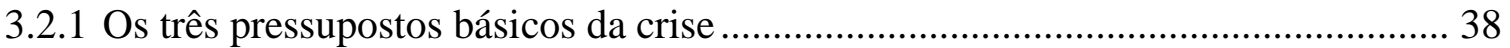

4 A PALAVRA, A AUTORIDADE E O SUJEITO CONTEMPORÂNEO ....... 48

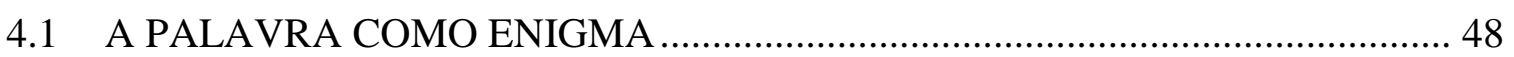

4.2 AUTORIDADE: AS CRIANÇAS “DE HOJE” E OS “NOVOS TEMPOS” ........ 53

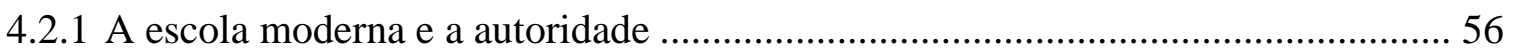

4.2.2 A mudança do lugar da autoridade no campo educativo ......................................... 61

4.3 ESVAZIAMENTO DA AUTORIDADE DA PALAVRA ...................................... 66

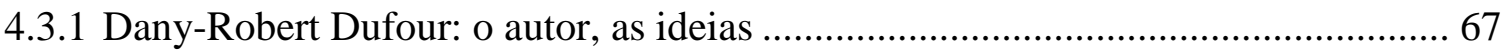

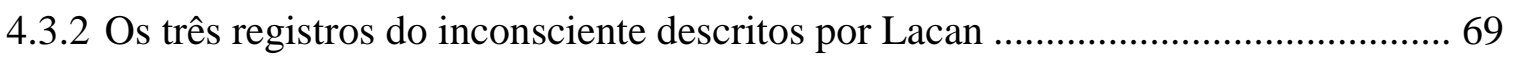

4.3.3 Por que esvaziamento e não perda da autoridade? ................................................. 75

4.4 DISCURSO DA CIÊNCIA COMO UMA NOVA FORMA DE SE RELACIONAR COM O SABER

5 ANÁLISE E REFLEX̃̃O DAS ENTREVISTAS COM PROFESSORES

DO ENSINO FUNDAMENTAL ........................................................................... 87

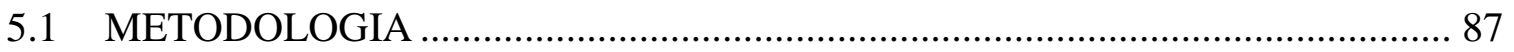

5.2 INDÍCIOS DO ESVAZIAMENTO DA AUTORIDADE DA PALAVRA NO DISCURSO DOS PROFESSORES .............................................................. 90

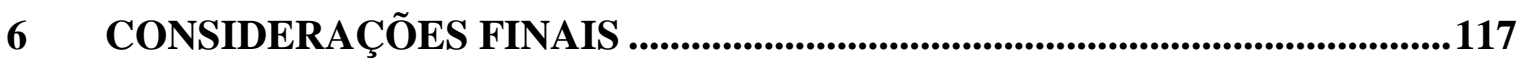

REFERÊNCIAS BIBLIOGRÁFICAS ...................................................................125

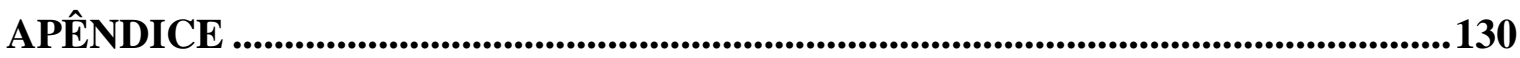


Eu escrevo por intermédio de palavras que ocultam outras - as verdadeiras. É que as verdadeiras não podem ser denominadas. Mesmo que eu não saiba quais são as 'verdadeiras palavras' eu estou sempre aludindo a elas. Meu espetacular e contínuo fracasso prova que existe o seu contrário: o sucesso. Mesmo que a mim não seja dado o sucesso, satisfaço-me em saber sua existência. 


\section{INTRODUÇÃO}

Esta introdução será dividida em duas partes: a primeira apresentará uma justificativa de caráter pessoal, um retorno às razões do empreendimento desta pesquisa, assim como aos motivos que me levaram à escolha da Pedagogia, especialmente sobre a importância da Psicanálise na condução dessa escolha e, finalmente, como tal escolha mobilizou uma questão de mestrado. A segunda parte trará uma explicação do nosso objeto de pesquisa juntamente com nossa hipótese.

Primeira Parte

Nossa história pessoal deixa marcas e, retomá-la, nos faz entender escolhas, sofrimentos e aprendizados. Somos seres humanos, portanto, permeados pela linguagem. Estamos em constante relação com os outros, sujeitos aos outros e isso nos causa transformação o tempo todo. Assim, pretendo retornar a meu passado para demonstrar o caminho percorrido por mim até chegar a esta pesquisa.

Minha relação com a Psicanálise e meu encantamento por suas reflexões iniciaram-se no Ensino Médio, quando o colégio em que estudava optou por um currículo diferenciado, chamado de Módulo, adicionado ao currículo comum. Os módulos eram projetos apresentados pelos professores com temas relacionados às suas disciplinas, no entanto, não do modo habitual, sendo mais relacionados à prática, à aplicação daquele conteúdo no dia-a-dia. Pretendia-se oferecer aos alunos a oportunidade de melhor compreender algumas profissões e talvez ajudá-los em suas escolhas no futuro.

No módulo de Matemática, pesquisamos como construir uma casa e planejar uma maquete; no de Química, escolhemos um produto para produzir desde a sua fase inicial de composição, sendo que a pesquisa também fazia parte do processo; no módulo de Português, trabalhamos com cinema e aprendemos sobre luz, áudio, culminando com um festival de curtas-metragens na escola. Era uma proposta muito interessante e nos convocava a responder à pergunta que a maioria dos alunos costuma fazer quando está na escola: Onde usarei esse conhecimento em minha vida?

O módulo que me instigou foi de uma matéria na qual já tinha certo interesse: Filosofia. O tema do módulo de Filosofia era "Freud e a Psicanálise" e, ao longo dele, assistimos ao filme Freud Além da Alma, lemos um livro sobre a vida e obra de Freud e, durante as aulas, discutíamos sobre a invenção da Psicanálise. 
A partir dos estudos nesse módulo, percebi que a Psicanálise fazia sentido para mim, talvez naquele momento como parte integrante da área de Filosofia, um modo de pensar sobre a vida humana.

É interessante lembrar brevemente - sabendo que "[...] na vida mental, nada do que uma vez se formou pode perecer[...], em circunstâncias apropriadas pode ser trazido de novo à luz.” (FREUD, 1996, p.78), ou seja, nada se perde em nosso aparelho psíquico - que, naquela época, como uma brincadeira por parte dos meus colegas, eu era considerada a "psicóloga" da turma, sempre os ajudando a refletir sobre seus problemas e aconselhando. Poderia pensar, nesse sentido, que a vestimenta que eu também aceitava, de algum modo me atingia como sujeito, na minha formação, e que retornaria muitos anos mais tarde.

A identificação que acontecera no Ensino Médio de alguma forma parecia ter desaparecido por um tempo, pois, no momento da decisão da Faculdade a cursar, optei por Hotelaria. Nas aulas do curso, no entanto, passei a ter a sensação de que meus questionamentos pessoais não se enredavam naquele contexto, além de sentir que não estava no lugar certo, que tudo que eu havia pensado e refletido no Ensino Médio, com relação à Filosofia, havia se perdido nas disciplinas daquela faculdade, pois o currículo de Hotelaria é bastante parecido com o do curso de Administração, área com a qual não tenho afinidade.

Demorei um pouco para constatar tudo isso, mas a decisão de que realmente aquele curso não servia para mim, custou-me um semestre da faculdade. Após me decidir por mudar de curso, refleti sobre as possibilidades mais relacionadas a mim e cheguei a duas opções: Pedagogia ou Psicologia. Prestei vestibular na Universidade Presbiteriana Mackenzie para cursar Psicologia e na Universidade de São Paulo para Pedagogia. Fui aprovada em ambos e então fiquei indecisa. A decisão, no entanto, não foi tomada segundo uma providência divina ou uma paixão ou ainda uma vocação, pelo contrário, foi bastante racional. Decidi-me por Pedagogia simplesmente porque não poderia pagar o curso na Universidade Mackenzie.

Apesar desse fato incontestável, ao iniciar o curso de Pedagogia, senti-me muito bem tanto com o ambiente quanto com as disciplinas. Enxergava, dessa vez, um vasto caminho de conteúdo sendo ensinado. O conteúdo inicial da faculdade estava ligado não às últimas palavras ou última moda em Educação, muito pelo contrário, remetia ao passado.

Introduzo, não ao acaso, a palavra "passado" neste momento, pois a presente pesquisa tem seu fundamento teórico na ideia de que é por ser inserido em uma história que um sujeito pode criar a sua. Em outras palavras, para a Psicanálise, o discurso do outro é incorporado pelo sujeito, apropriando-se de uma história que é sua, mas é dada pelo outro. Um exemplo disso é o nome próprio, que ao mesmo tempo que é identidade pessoal, foi dado por outro. 
São, portanto, as marcas da palavra e da linguagem incorporadas pelo sujeito. A palavra "passado" também remete à tradição, tema que desenvolveremos com as ideias principais de Hannah Arendt sobre a perda da tradição e consequentemente da autoridade e finalmente o que isso ocasiona na sociedade contemporânea e seus efeitos na Educação. Enfim, o curso de Pedagogia fazia-me questionar muito mais do que o curso anterior, pois, sob minha ótica, estava entregando um legado para que pudéssemos (futuramente como professores) ter um novo olhar sobre o passado. Ou seja, para assumirmos a responsabilidade pelo mundo (ARENDT, 2013), no caso, para que fôssemos professores, teríamos que conhecê-lo e, para que isso acontecesse, seria necessário que alguém que aqui está há mais tempo nos apresentasse às coisas.

Durante o curso, deparei-me com um incômodo constante, pois, ao conversar com meus colegas sobre os motivos de terem escolhido a Pedagogia e, mais especificamente, escolhido serem professores(as), surgiam inúmeras vezes a seguinte resposta: "Quero ser professor porque gosto de crianças”. Isso me incomodava, pois enxergava nesse discurso uma visão romântica da Educação ${ }^{1}$, poderia até dizer um discurso totalizante, que pretendia ser pleno e fechar, em uma resposta, todas as vicissitudes que o encontro de um adulto com uma criança faz surgir. Por que eu teria prestado atenção nas falas daqueles colegas e por que isso me incomodava?

Acredito que a minha escuta, ou seja, ouvir daquela maneira as falas dos colegas, possibilitava-me entender meu próprio motivo de escolha. Foi naquele momento que algumas aulas de Psicologia da Educação e outras optativas me reaproximaram da Psicanálise e este reencontro fez com que perguntas fossem "respondidas", tanto na minha própria busca pelas razões de escolha da Pedagogia, quanto nos motivos do incômodo que me causavam as falas de meus colegas.

É interessante notar que foi exatamente ali, no modo como a Psicanálise pensa a Educação, que eu me encontrei e encontrei respostas para alguns de meus questionamentos. A princípio pode parecer contraditório, pois a Psicanálise propõe-se a dar respostas não-todas, isto é, “[...] um saber que nunca é total ou totalizante.” (MRECH, 2005, p.145). Em outras palavras, não há resposta que faça com que o sujeito pare de se perguntar. Ou ainda, não há palavras que respondam com totalidade uma pergunta, diferindo assim, de um discurso totalizante. Diferentemente do que atribuímos às Ciências, nenhuma resposta consegue englobar e decifrar toda uma pergunta.

\footnotetext{
${ }^{1}$ Esta relação será desenvolvida com maior clareza na segunda parte da introdução.
} 
Um momento pontual, com relação a essas perguntas, em minha formação, foi bastante interessante para refletir sobre o incômodo com o discurso de meus colegas. No início do curso de Pedagogia, é costume cada turma elaborar uma camiseta para recordação do trajeto acadêmico. Minha turma estampou a seguinte frase de Hannah Arendt (2013): “A Educação é o ponto em que decidimos se amamos o mundo o bastante para assumirmos a responsabilidade por ele[...]" (p.247). Portanto, é o amor pelo mundo que move o professor, talvez não tanto numa visão romântica, mas sim para que aquele não acabe em ruínas pois, como nos diz Arendt, temos que proteger o mundo das crianças e as crianças do mundo. E, para protegê-lo, muitas vezes temos que barrar essas crianças, no sentido de não deixar que o amor por elas ponha em risco nossa humanidade.

\begin{abstract}
A responsabilidade pelo desenvolvimento da criança volta-se em certo sentido contra o mundo: a criança requer cuidado e proteção especiais para que nada de destrutivo lhe aconteça de parte do mundo. Porém também o mundo necessita de proteção, para que não seja derrubado e destruído pelo assédio do novo que irrompe sobre ele a cada nova geração. (ARENDT, 2013, p.235).
\end{abstract}

Enfim, acredito que para ensinar crianças é preciso sim que gostemos delas, cada um a seu jeito, mas saliento aqui que, como Arendt, percebo a necessidade de protegermos nosso mundo como um legado a ser passado para os mais novos, ou seja, cursar Pedagogia, a meu ver, seria uma forma de conhecer este legado muito mais do que conhecer as crianças, pois, delas, tudo podemos esperar. Sabendo nosso papel como antes aqui chegados e tendo histórias para contar é que poderemos, aí sim, simplesmente gostar delas e educá-las, pois serão representantes da continuidade do mundo.

\title{
Segunda Parte
}

Para que uma reflexão aconteça há que existir algo com que nos impliquemos, que nos "fisgue", nos incomode, enfim, algo que nos faça movimentar em direção a um desejo, ou poderíamos dizer que é ele que nos faz movimentar, assim como acontece quando se permite uma aprendizagem. Pensar a Educação a partir de uma perspectiva da Psicanálise foi o que me permitiu a movimentação na Pedagogia.

Como já introduzi anteriormente, no início de minha formação encontrava-me às voltas com uma inquietação que surgia com as falas de minhas colegas do curso de Pedagogia, quando justificavam ter escolhido o curso por gostarem de crianças e também 
sobre os debates acerca da função do professor. Essas falas, em minha opinião, partiam de uma visão romântica da Educação e acredito que tal visão possibilita entender como se configura a Educação na atualidade.

A expressão "visão romântica" simboliza a forma como o discurso comum direciona o olhar para a Educação em nosso tempo. A Educação estaria, segundo nosso ponto de vista, inserida em uma visão romântica do mundo, como uma forma de enxergá-lo. Apesar de ser um termo tomado da literatura, parece- me que se encaixa nas razões de meu incômodo no decorrer do curso de Pedagogia. Sendo assim, dedicarei um tempo para explicar essa relação.

Tal expressão refere-se ao movimento do Romantismo que teve origem na Escócia e na Prússia, segundo o Dicionário de termos literários (MOISÉS, 1986). O termo romântico foi utilizado pela primeira vez em meados de 1600 e sua difusão deu-se a partir dos primeiros anos do século XIX. De acordo com o mesmo dicionário, o termo romantismo "[...]acabou significando nada à custa de significar tudo[...]" (MOISÉS, 1986, p.461), ou seja, esvaziou-se de sentido em busca de dar todas as respostas, bastante parecido com o que vemos acontecer com a Pedagogia e pretendemos discutir nesta pesquisa. Ultrapassou o âmbito literário, sendo considerado verdadeira revolução cultural e modificou os padrões humanos em diversas áreas como filosofia, padrões morais, políticos e estéticos.

O movimento baseava-se na centralidade do indivíduo, "o eu se exibe liricamente na singularidade dos sentimentos e da imaginação" (COELHO, 1973, p.964), ou seja, a partir da introspecção dos sentimentos, eram atribuídas novas significações ao mundo, em uma visão idealizada, como uma afronta aos clássicos e às regras na produção literária.

Ainda sobre o movimento egocêntrico, os românticos colocavam "as razões do coração em lugar do racionalismo, o sentimentalismo em vez da especulação ou investigação “científica", cultuavam a imaginação desenfreada" (MOISÉS, 1986, p.463). A imaginação, as tendências idealistas, como uma visão de mundo, estavam arraigadas ao movimento do Romantismo. A tendência a enxergar o ser humano como fonte da salvação para os males da sociedade tem congruência com as ideias de Rousseau, do homem naturalmente bom: "Algumas vezes aflora, segundo a lição de Rousseau, a ideia da bondade natural do indivíduo, pervertido e constrangido pela sociedade". (COELHO, 1973, p.964).

Parto dessa ideia de idealização do mundo para compará-la à visão romântica de meus colegas, como sendo uma idealização de escola e consequentemente uma idealização da criança. Na fala dos alunos, percebe-se essa idealização ao dizerem ter escolhido a Pedagogia por gostarem de crianças, pois gostamos, na verdade, das crianças ideais, por exemplo, as educadas, as que escutam, as que querem aprender, ou ainda, aquelas que se encaixam e 
completam nosso imaginário. Ao se depararem com as crianças do dia-a-dia da escola, os professores sofrem com o choque do real, desmontando aquela criança ideal e com isso, estar no lugar do professor pode vir a ser algo muito angustiante e desafiador. Muitas vezes, esses encontros resultam nos famosos sintomas do âmbito da Educação como a síndrome de burnout, mal-estar docente, entre outros sintomas que atingem aqueles que tentam lidar com o (des)encontro inevitável do professor com o aluno.

Muito provavelmente foi o conflito com o discurso romantizado da Educação o responsável por criar outra demanda dentro da minha trajetória no curso, ou seja, instigar a busca por razões outras de uma escolha, além de me colocar de uma forma diferente com relação ao debate pedagógico. São as inquietações marcadas pela busca de uma forma diferente de ver a Educação que me levaram a "escutar" na Psicanálise uma possibilidade minha na Educação, permitindo-me questionar: Como e por que uma reflexão psicanalítica pode nos tirar do discurso que toma conta da Educação contemporânea? Esse discurso seria também o que posteriormente se tornou totalizante e hegemônico, visando o encaixe perfeito entre ensino e aprendizagem.

Vários aspectos do referido discurso me capturaram ao longo destes anos como estudante de Pedagogia e de docência (sou professora de Educação Infantil desde 2006), mas com o tempo percebi que quase todos eles giravam em torno do mesmo tema, a autoridade.

No início do mestrado, o projeto que apresentei tinha como tema a patologização da aprendizagem, aparentemente ainda um pouco distante do tema da autoridade. Naquela proposta, eu pretendia discutir e denunciar a forma "patológica" do modo de educar contemporâneo, porém a todo o momento em que sugeria a discussão, minha pesquisa era entendida no âmbito de medicalização da Educação e problemas de aprendizagem e a princípio me envolvi com essas temáticas, mesmo sabendo que a questão a ser discutida era um pouco mais profunda e obscura, no avesso daquela que se propunha.

Assim que chegou o momento de formular uma questão de pesquisa, deparei-me com as minhas reais inquietações sobre Educação, formulando provisoriamente uma questão: Em nome do que o professor ensina na contemporaneidade? Foi a partir desse questionamento que emergiu a possibilidade de pensar a autoridade, a crise na Educação e o mal-estar contemporâneo, pois a Educação deve ser feita em nome de algo, ou seja, deve-se remeter a um passado intrínseco à vida humana em sociedade, desses seres que se comunicam, ou ainda, em nome do desejo que lhes habita. Enfim, educar em nome de não renunciar à própria educação, ou ainda, estar ali “de corpo e alma” como alguém que aqui está há mais tempo. 
Kupfer (2007a) põe em outras palavras essa formulação, dizendo que "[...]todo exercício profissional exige[...]que se estenda sobre ele uma rede imaginária e simbólica que liga, articula, valoriza, prestigia, e, portanto atribui significação à prática individual de seus participantes.” Já para Arendt (2013), é como se o professor fosse “[...] um representante de todos os habitantes adultos, apontando os detalhes, dizendo à criança: - Isto é o nosso mundo." (p.239).

Nesse sentido, a ideia central do encaminhamento da resposta seria desvendar o que havia mudado na Educação para não se educar mais "em nome de", trazendo a discussão para o campo do declínio da autoridade na Educação. Acreditávamos, naquele momento, que essa pergunta estava em um plano extremamente psicanalítico e metalinguístico, em um nível elevado de conhecimento sobre Psicanálise, não sendo possível abarcar no mestrado. Assim, nos conduzindo inevitavelmente a reformular o raciocínio.

Nessa incessante e incansável (ou inalcançável) busca pelo objeto de pesquisa, deparei-me com diversas falas de professores e não professores, num discurso que me gerava incômodo. Incômodo não apenas no sentido de tentar respondê-las, mas sim pensando porque tais falas se repetem tanto no momento atual e o que delas podemos extrair para refletir sobre a forma de sujeito contemporâneo que se manifesta. Reproduzo aqui algumas delas: "a escola perdeu seu lugar de autoridade", "não ensina efetivamente mais nada", "os alunos estão desinteressados pelo que a escola propõe", "os alunos vão para a escola por nove anos e saem praticamente analfabetos", “os alunos não escutam e os professores já não têm mais estofo teórico nem energia para lidar com esse novo tipo de aluno".

Todas essas queixas passaram a me incomodar. Meu incômodo não se dava, no entanto, somente na direção do dito fracasso escolar e das dificuldades de aprendizagem, mas sim da deslegitimação do professor e da escola na sociedade contemporânea. Foi tomando forma meu objeto de pesquisa, especialmente no que tange à reflexão sobre a tensão entre os discursos correntes, de que a velha escola não é mais adequada à nova geração e de que os alunos não querem mais ouvir o que os professores têm a dizer. A investigação ia, assim, se encaminhando para a discussão sobre a palavra do professor na Educação.

Nesse momento, a leitura do livro A arte de reduzir as cabeças: sobre a nova servidão na sociedade ultraliberal de Dany-Robert Dufour (2005a), sobretudo o capítulo O hommo zappiens na escola: a negação da diferença geracional trouxe novos ares para a discussão que se estava configurando.

Resumidamente e simplificadamente, a ideia central do livro é propor que existe uma nova forma-sujeito sendo instalada, ou até mesmo fabricada, a partir dos mecanismos do 
neoliberalismo, com sua força dada pelo capitalismo. Surgiria, então, o sujeito pós-moderno no lugar do duplo sujeito da modernidade, que seria o sujeito crítico (kantiano) e o sujeito neurótico (freudiano) (DUFOUR, 2005a).

Essa discussão é muito importante no que se refere ao tema que decidi, por final, discutir e faremos isso mais adiante. Por ora, chamo a atenção para um momento bastante pontual dessa obra que me capturou, para assim tornar-se questão de investigação e pesquisa. Tal momento situa-se no que o autor nomeia de perda da autoridade da palavra, dizendo que os alunos não falam mais baseados na autoridade da palavra e, além disso, demonstra, também, que os professores enfrentam a dificuldade de colocar os alunos na posição de alunos ou, em outras palavras, os próprios alunos não se posicionam como alunos, como aqueles que escutam.

Algo me capturou nas palavras de Dufour pelo fato de trazer à tona, ainda que de outra forma, o discurso correntemente repetido sobre o mal-estar que acomete a Educação, seja ele de uma forma real, com a qual temos (professores) que nos haver frente ao aluno ou sendo uma crise que dá oportunidade para avançarmos no assunto. Em outras palavras, ao propor a discussão sobre a perda da autoridade da palavra, o autor traz não só as vicissitudes do encontro entre professor e aluno, mas retoma os fatores do mal-estar na Educação, enraizados na tão paradoxal crise da autoridade contemporânea.

Digo paradoxal, pois, ao mesmo tempo que uma face do discurso do senso comum divulga a crise da autoridade como culpada de todos os problemas da Educação e das dificuldades do professor, dizendo que hoje, por não haver mais autoridade como a conhecíamos outrora, todos os ofícios que, segundo esse pensamento, dela dependem estão fadados ao fracasso; outra face atribui à crise da autoridade a possibilidade dessa vir a ser a "redentora" da sociedade contemporânea, como possibilidade de traduzir em novas palavras a autoridade ou mesmo a falta dela, ou seja, reformular e rever paradigmas, fazer novas perguntas, mesmo que as respostas sejam as velhas, "uma crise nos obriga a voltar às questões mesmas e exige respostas novas ou velhas, mas de qualquer modo julgamentos diretos" (ARENDT, 2013, p.223).

Mesmo tendo sido capturada pelo discurso da perda da autoridade da palavra, não dei por encerrado o assunto, e é aí que um mero objeto de estudo torna-se questão de investigação, primeiramente porque não estou totalmente convencida nem de um lado, nem de outro e é a tensão gerada por esse embate que move uma pesquisa, como Dunker $(2010)^{2}$ nos

\footnotetext{
${ }^{2}$ Sem numeração de páginas
} 
elucida, em artigo de estilo paródico, sobre os questionamentos de um pesquisador: "Se você veio para a pós graduação para chancelar e aprovar o que você já sabe, volte para casa número 2. Por aqui interessam boas perguntas, não só respostas".

A suposição de perda da autoridade da palavra surge então como um enigma, uma possibilidade de decifração de algo obscuro, porém sem a pretensão de oferecer uma resposta sintética. Nossa hipótese é que não é possível falar em perda da autoridade da palavra na Educação, mas sim em um esvaziamento, como uma das formas que a crise na Educação pode tomar.

Manifestam-se alguns questionamentos a partir desta hipótese: será que o esvaziamento da autoridade da palavra poderia afetar o esvaziamento do enigma que permite a aprendizagem? Será que essas mudanças na aprendizagem, que às vistas da contemporaneidade parecem ser inevitáveis, não podem vir a ser benéficas de alguma forma para os sujeitos contemporâneos?

Tais questionamentos levaram-me a refletir sobre o tema e a delinear alguns objetivos deste trabalho: demonstrar como a Psicanálise pode contribuir para a compreensão da Educação, da crise da Educação e da autoridade da palavra do professor diante de tal crise; e apresentar uma reflexão acerca do possível esvaziamento da autoridade da palavra do professor na contemporaneidade como provável consequência da crise na Educação.

Nos três próximos capítulos desta dissertação, portanto, pretendemos apresentar as teorias que fundamentarão os objetivos e esclarecerão os questionamentos levantados.

No segundo capítulo, pretendemos entender a relação que a Psicanálise vem tecendo com a Educação há algum tempo, a qual é de extrema importância para que possamos tanto limitar essa relação quanto refletir sobre os ganhos que ela traz acerca das vicissitudes na Educação.

No terceiro capítulo, nossa intenção é balizar um panorama da crise na Educação ao trazer primeiramente o olhar de Freud em Mal-estar na civilização indicando o próprio mal-estar como aquele que funda nossa condição (humana) de civilizados e assim instaura uma falta que, por sua vez, será nossa condição estrutural de insatisfação. Já o olhar de Hannah Arendt, para a crise na Educação, permite um mergulho mais profundo no mal-estar contemporâneo, pontuando a crise como uma consequência do modo de sermos sujeitos modernos e quanto isso afetou (e afeta) a Educação.

O quarto capítulo tem a finalidade de recortar a discussão para refletirmos sobre o que entendemos por esvaziamento da autoridade da palavra em nossa pesquisa, assim como alinhavar e pontuar nossa utilização da Psicanálise como base ética e reflexiva para desdobrar nossos questionamentos e hipóteses. Demonstraremos, primeiramente, uma pesquisa sobre a palavra, oferecendo a posição que tomamos sobre ela para investigar tanto sobre sua 
autoridade quanto sobre seu esvaziamento. Isto posto, partiremos para entender como a autoridade vem tomando outras formas e lugares no discurso e, logo depois, faremos um esclarecimento acerca dos três registros do inconsciente calcados por Lacan para fundamentar e esclarecer alguns posicionamentos dos quais tomamos parte nesta pesquisa. Em seguida, discutiremos as ideias de Dufour sobre a perda da autoridade da palavra, articulando-a com todo o pensamento que construímos ao longo da pesquisa. Por fim, entenderemos como o discurso da ciência sustentou e sustenta o modo como os sujeitos funcionam na contemporaneidade.

Finalmente, o quinto capítulo apresenta entrevistas com oito professores da rede municipal de São Paulo com o intuito de analisar qual a percepção que o professor tem da sua palavra diante dos alunos, ou seja, quais são os significantes e as queixas que aparecem em suas falas que, por sua vez, nos permitem encontrar indícios do esvaziamento da autoridade de sua palavra. É nesse ponto que pretendemos alinhavar o contato entre Educação e Psicanálise: a escuta dos professores, a análise de suas falas segundo Freud e Lacan e a análise de como enxergam a autoridade de sua palavra pelos alunos. 


\section{POR QUE UTILIZAR A PSICANÁLISE PARA FALAR DE EDUCAÇÃO?}

Esta pesquisa desenvolve-se nos campos da Psicanálise e da Educação. Nas próximas linhas demonstraremos porque acreditamos haver uma aproximação entre elas. Tal afinidade não é recente, tampouco inovadora, mas no âmbito da Psicanálise, a cada novo olhar se tece uma forma única de investigar, pois a escrita traz em si algo do sujeito, de sua forma de elaborar um tema específico.

Retomar um lugar de dizer não é a mesma coisa que repetir os ditos, mas pelo contrário, abrir a possibilidade de que ditos sempre novos possam se produzir. Dizer de novo (do mesmo lugar, uma vez mais) permite dizer do novo, dizer ditos novos. (ELIA, 1999).

Alguns autores já fizeram essa aproximação e seus ditos serão utilizados para tentar responder a pergunta deste capítulo: Por que utilizar a Psicanálise para falar de Educação?

Sigmund Freud, o pai da Psicanálise, não tratou em seus textos exclusivamente da Educação, muito menos da Pedagogia, mas sua obra é permeada a todo tempo pelo tema, fazendo uma "aposta na Educação como instrumento para mudança" (VOLTOLINI, 2011, p.15). Freud desenvolveu algumas questões com as quais podemos estabelecer relações com a Educação, como: "os impasses dos pais no esclarecimento sexual das crianças, o peso de uma Educação moralizante, excessivamente repressora e seu impacto sobre o aumento do adoecimento neurótico da população, além do tortuoso caminho percorrido pela cria humana nos interstícios de sua sexualidade para tornar-se homem, Freud adentrou modestamente, mas de maneira singular, o campo da Educação". (VOLTOLINI, 2011, p. 9).

$\mathrm{O}$ estudioso enunciou algumas vezes ${ }^{4}$ que existem três profissões impossíveis: governar, educar e psicanalisar. Segundo ele, o aforismo do impossível de educar passa pela impossibilidade de estabelecer uma relação de causalidade entre os meios e os fins do ato de educar e principalmente pelos efeitos do endereçamento entre professor e aluno.

Todo aquele que se aventurar no campo educativo (haverá alguém que possa escapar dele?) terá que se confrontar, mais cedo ou mais tarde, com a decepção. Os resultados atingidos estarão sempre aquém daqueles imaginados no ponto de partida. Entre os fins vaticinados e os meios postos em prática para sua execução, quaisquer que sejam eles, haveria uma impossibilidade lógica. É isso o que esse aforismo pretende sustentar. (VOLTOLINI 2011, p.27).

As ilusões, que rodeiam o ato educativo pela busca de controle dos efeitos da palavra, caminham no mesmo sentido da "visão romântica" que desenvolvemos anteriormente, ou

\footnotetext{
${ }^{3}$ Sem numeração de páginas.

${ }^{4}$ Prefácio ao livro Análise terminável e interminável de A. Aichorn(1925)
} 
seja, “[...] visam abortar, paradoxalmente, a possibilidade de que aconteçam efeitos educativos e subjetivantes" (LAJONQUIÈRE, 1999, p.22). É a isso que nos referimos quando estamos falando em "impossível”, não no sentido de que a Educação não acontece, mas, em se tratando do direcionamento de palavra a outro sujeito, os efeitos dessa palavra são impossíveis de prever. Poderíamos concluir, portanto, que o impossível da Educação é a própria barreira da linguagem. Ou seja, as impossibilidades nesse sentido "não aludem ao plano prático de execução de uma determinada proposta educativa" e, além disso, o impossível "não quer dizer inexequível, apontando, antes, para um inalcançável estrutural". (VOLTOLINI, 2011, p.25).

De forma alguma essa colocação pode servir-nos como redutora das aproximações com a Educação, ao contrário. Acreditamos que, ao investigar sobre esse impossível, abrimos portas para entender e perguntar sobre as implicações da Psicanálise.

Lacan, em continuidade à obra psicanalítica de Freud, ampliou e elevou a Psicanálise a outros patamares, incluindo também a Educação (e sua crítica) em seus estudos. Segundo Mrech (2005, p.16), de um lado Freud estabelecia uma crítica à concepção moderna de Educação "ao destacar que reduzia o sujeito a um simples apêndice da sociedade, ao se nortear por ideais sociais e culturais gerais" de outro Lacan "criticou o modelo normativo e prescritivo da Educação" uma concepção complementaria a outra, concluindo a autora que "a Psicanálise e a Educação apresentavam caminhos inteiramente opostos”, sem deixar de lado a possibilidade de se implicarem uma com a outra.

A presença do tema Educação na obra de Lacan adquire uma forma, poderíamos dizer, mais investigativa, refletindo não só sobre a educação num âmbito familiar e escolar, mas também do próprio ensino da Psicanálise e de seus diversos usos na sociedade. Se para Freud era "[...]com um interesse médico, o da profilaxia das neuroses[...]que chega até o tema da Educação" (VOLTOLINI, 2011, p.13), para Lacan

A presença em sua obra de termos como escola, ensino, transmissão, discurso universitário, análise didática[...], além das propostas como a criação de cartéis e de seminários, não deixa dúvidas de que nesse autor, ainda que não de forma explícita, como em Freud, o tema do educar adquire uma importância capital. (VOLTOLINI, 2011, p.66).

Portanto, parece-nos que, em Freud, o tema Educação surge com mais clareza como objeto de estudo, já em Lacan está arraigado ao próprio estilo do autor em transmitir e propagar o ensino da Psicanálise para outros campos. 
Kupfer (2007b) apresenta a Psicanálise aos professores em seu livro Freud e a Educação: O mestre do impossível, aproximando mais uma vez o campo da Educação ao campo da Psicanálise, porém, alertando para a impossibilidade da aplicação da Psicanálise ao campo da Pedagogia, ou seja, não foi com a intenção de gerar mais uma ferramenta ou metodologia para esse campo, mas, sim, como uma implicação, fazendo surgir pesquisas e inquietações de professores, mas somente isso. Nas palavras de Kupfer, ela delimita o encontro entre Psicanálise e Educação:

[...] a Psicanálise pode transmitir ao educador (e não à pedagogia, como um todo instituído) uma ética, um modo de ver e de entender sua prática educativa. É um saber que pode gerar, dependendo, naturalmente, das possibilidades subjetivas de cada educador, uma posição, uma filosofia de trabalho. Pode contribuir, em igualdade de condições com diversas outras disciplinas, como a antropologia, ou a filosofia, para formar seu pensamento. Cessa aí, no entanto, a atuação da Psicanálise. Nada mais pode se esperar dela, caso se queira ser coerente com aquilo de que se constitui essencialmente a aventura freudiana. (KUPFER, 2007b, p.97).

Pensaremos a Psicanálise como aquela que possibilita pensar a Educação e suas vicissitudes de maneiras diversas, sem deixar de conhecer seu impossível. Como nos diz Kupfer, introduzi-la como um saber a mais, uma implicação com a Educação e não um modo de buscar respostas sobre a Educação.

Mrech (2005) também alerta para os perigos que incorremos nessa aproximação entre Psicanálise e Educação, riscos sempre iminentes à prática pedagógica ao pretender tornar a Psicanálise mais uma fórmula de aplicação metodológica dos saberes "psi” como aqueles que podem dar respostas aos problemas da Educação.

Neste ponto, um certo cuidado é essencial. É preciso não entificar essas
descobertas, fazendo com que as conexões que se mostraram possíveis se
transformem em conexões puras e simples. Por quê? Porque elas ocorreram
em um circuito relacional. Um circuito não se perpetua nunca da mesma
forma. Ele se transforma, ele se transmuta. Ele constitui sempre outra coisa.
(p.178).

Utilizar a Psicanálise para falar sobre Educação é, portanto, refazer e tecer esse circuito que nunca se dá por finalizado. É também valer-se de uma área de pesquisa que estuda o sujeito do inconsciente e sua palavra para entender algumas vicissitudes do processo de aprendizagem, sobre o que permeia o "ser professor" e, finalmente, aquilo que não se pode saber, ou seja, a falta fundante do sujeito, o furo, o que sempre restará no ato educativo. Sobre isso nos elucida Mrech (2005): 
Lacan revela que para o inconsciente há sempre um rombo, um rasgo no saber[...] O que interessa ao ensino da Psicanálise é trabalhar sobre algo que não se pode saber. Não porque haja uma proibição em relação ao saber, mas porque há um limite em relação a um tudo saber. Um limite introduzido pelo registro do real. (p.145).

A intenção aqui é demonstrar que esse limite, essa relação não-toda com o saber que a Psicanálise nos faz enxergar sobre a Educação é o que provavelmente permite a aprendizagem e também que o professor entenda que não detém o saber, mas que precisa estar presente para seus alunos e com isso "se descole daquilo que a sociedade proponha para ele" (MRECH, 2005, p.154).

Nesse sentido, parece-nos impossível falar sobre Educação sem a presença intrínseca e ao mesmo tempo crítica da Psicanálise, todavia, sem embarcar em um tom de denúncia. Assim como na Introdução apresentamos a importância pessoal do discurso psicanalítico e da escuta psicanalítica para nosso empreendimento na área da Educação (justificada pela nossa opção de escutar os professores para entender o que eles sentem com relação ao esvaziamento da autoridade da palavra do professor), agora também apresentamos sua importância teórica. Assim se configura, portanto, nossa justificativa de utilização da Psicanálise para falar de Educação. 


\section{PANORAMA DA CRISE NA EDUCAÇÃO}

Para dar início à nossa investigação sobre a contemporaneidade e o mal-estar que a rodeia, utilizaremos o ensaio Mal-estar na civilização (FREUD, 1996), publicado originalmente em alemão no ano de 1929, cujo tema central é o embate entre as cobranças do instinto e as restrições da civilização. Posteriormente entenderemos como a crise na Educação se configurou de maneira pontual na contemporaneidade, através do ensaio de Hannah Arendt (2013)

\subsection{O MAL-ESTAR NA CIVILIZAÇÃO COMO ESTRUTURAL}

Freud inicia o texto esclarecendo que se trataria de uma investigação essencialmente sobre a felicidade, retomando seu texto anterior, O futuro de uma ilusão, para demonstrar as ilusões que a religião pode causar em uma sociedade. A função da religião para o homem seria uma medida paliativa para explicar os enigmas do mundo. Diz-nos ele que "[...] a vida como a encontramos, é árdua demais para nós; proporciona-nos muitos sofrimentos, decepções e tarefas impossíveis. A fim de suportá-la, não podemos dispensar as medidas paliativas" (FREUD, 1996, p.83)

Nessa concepção, o estudioso afirma que o propósito da vida humana não recebe resposta, talvez porque não o seja possível, porém a religião é uma das instituições que tenta formular e oferecer tais respostas. Nesse ponto do texto o foco se volta para o que exatamente os homens tomam como o propósito de suas vidas e não o propósito da vida humana em geral. Os homens, portanto, querem ser felizes, visam à ausência de desprazer e sofrimento, buscando, ao mesmo tempo, experiências de intenso prazer.

\subsubsection{Felicidade X infelicidade}

A felicidade - propósito da vida do homem - estaria ligada somente ao prazer ou, em suas palavras, "o que decide o propósito da vida é simplesmente o programa do princípio do prazer" (FREUD, 1996, p.84). Ele nos diz que este princípio desde o início da vida domina o aparelho psíquico, movendo o sujeito pelas contrariedades do mundo. Esse princípio se mostra eficaz, pois, mesmo que não seja possível ao homem alcançar a felicidade completa, ele o utiliza como impulsionador da vida, fazendo com que queira continuar vivendo e buscando o prazer. 
Quando qualquer situação desejada pelo princípio do prazer se prolonga, ela produz tão-somente um sentimento de contentamento muito tênue. Somos feitos de modo a só podermos derivar prazer intenso de um contraste, e muito pouco de um determinado estado de coisas. (FREUD, 1996, p.84).

A felicidade é definida por ele como uma manifestação episódica, ou seja, só é prazerosa enquanto ocupa um curto espaço de tempo. Em outras palavras, seria uma satisfação de algum desejo ou necessidade represada em um dado momento.

Como não seria complicado prever, a infelicidade é muito menos difícil de experimentar, conclui Freud. O homem convive com o sofrimento a todo tempo em sua vida, assim, o sofrimento o atingiria e ameaçaria em três direções: a partir do corpo, do mundo externo e da relação com os outros.

Freud (1996) considerou a terceira direção a mais importante a ser estudada e discutida naquele momento. Nomeada como "nossos relacionamentos com os outros homens" (p.85), é a partir dessa direção, de onde o sofrimento provém, que o autor irá investigar sobre a felicidade do homem, fazendo-nos perguntar: Por que é tão difícil para o homem ser feliz?

Sobre essa dificuldade, Freud alerta que, algumas vezes, a busca da felicidade se vê invertida, fazendo com que o homem prefira o isolamento voluntário para evitar entrar em contato com a infelicidade, movimento que irá, segundo ele, atingir apenas a felicidade da quietude. Podemos pensar, nesse sentido, que a religião oferece essa possibilidade, já que escolhe não entrar em contato com o real do sofrimento, ou seja, oferece um mundo de ilusões ao qual o homem se segura.

Ao retomar as três fontes do sofrimento, o autor as formula de forma diferente, descrevendo a terceira agora como sendo uma "inadequação das regras que procuram ajustar os relacionamentos mútuos dos seres humanos na família, no estado e na sociedade" (FREUD, 1996, p.93) e traz para esta terceira uma discussão que permeia toda sua análise e que será de imensa importância para seus estudos e hipóteses iniciais sobre a convivência entre os homens: o instinto.

Os ajustes dos relacionamentos seriam, por sua vez, dados pela civilização e pelo modo como convivemos uns com os outros, mas para Freud há uma inadequação, que gera uma atitude de hostilidade do homem para com a civilização, concluindo, portanto, que a civilização seria a responsável pela desgraça do homem, "[...]o que chamamos de nossa civilização é em grande parte responsável por nossa desgraça[...]”. (FREUD, 1996, p.93) É possível pensar que assistimos hoje a uma mesma posição acerca da modernidade, muitas vezes associada a todos os males contemporâneos. Birman (2005) afirma que a própria 
investigação de Freud sobre o mal-estar estaria arraigada no sujeito moderno e não tanto na razão entre o instinto e as leis da civilização, como se pode acreditar no início:

[...]considerei que o que estava em questão neste desenvolvimento teórico era menos a relação de antinomia insuperável entre os polos da pulsão e da civilização, numa forma de reflexão resignada da subjetividade na civilização em geral, do que num esforço para circunscrever o mal-estar do sujeito na modernidade. (BIRMAN, 2005, p.17).

O mal-estar do sujeito na modernidade é peça essencial para entendermos o mal-estar na civilização, porém, desenvolveremos mais adiante essa relação do sujeito com a modernidade, o mal-estar e a crise na Educação. Por ora, prosseguiremos desvendando as ideias de Freud acerca do que chamou de mal-estar na civilização.

O sentimento de hostilidade derivaria, dessa forma, da insatisfação com o estado de civilização existente. Freud nomeia sua descoberta do mecanismo das neuroses e o conhecimento de todos por parte disso como um dos fatores da insatisfação. Ele afirma que

[...] uma pessoa se torna neurótica porque não pode tolerar a frustração que a sociedade lhe impõe, a serviço de seus ideais culturais, inferindo-se disso que a abolição ou redução dessas exigências resultaria num retorno às possibilidades de felicidade. (FREUD, 1996, p.94).

Parece-nos que Freud denuncia as exigências e frustrações impostas pelo modo de funcionamento da sociedade como culpados da insatisfação do homem, impedindo um funcionamento teoricamente mais saudável do inconsciente humano.

Nesse caso, sustenta a hipótese de que o maior poder sobre a natureza poderia lhes trazer um sentimento maior de satisfação e felicidade, porém, não foi desse modo que Freud (1996) avaliou o progresso da civilização. Apesar do “[...] poder recentemente adquirido sobre o espaço e o tempo, a subjugação das forças da natureza, consecução de um anseio que remonta milhares de anos, não aumentou a quantidade de satisfação prazerosa que poderiam esperar da vida e não os tornou mais felizes". (p.94)

Conclui-se que "[...] o poder sobre a natureza não constitui a única precondição da felicidade humana, assim como não é o único objetivo do esforço cultural” (FREUD, 1996, p.95). A nosso ver o que Freud pretende salientar, e o que podemos inferir disso, é que mesmo com os avanços da tecnologia, que naquela época - final dos anos 1920 - já produziam efeito sobre o modo como as pessoas viviam, a infelicidade parece surgir como uma estrutura arraigada à condição humana, não sendo possível modificá-la permanentemente 
e, como Freud aponta, a felicidade ocupa um breve espaço de tempo e se não for dessa maneira, passa a não constituir o próprio sentimento de felicidade.

Retomando a ideia anterior, de que a abolição ou redução das exigências da civilização poderiam aumentar o sentimento de satisfação ou felicidade, Freud faz uma afirmação que é até hoje lembrada quando nasce uma nova geração: "Parece certo que não nos sentimos confortáveis na civilização atual, mas é muito difícil formar uma opinião sobre se, e em que grau, os homens de épocas anteriores se sentiram mais felizes e sobre o papel que suas condições culturais desempenharam nessa questão." (p.95). Ou seja, em todas as épocas se imagina que a anterior possa ter sido melhor - o próprio sentimento nostálgico, tipicamente neurótico - pois o homem vive de lembranças e vive de sua miserável condição humana. Talvez não consiga viver de outra forma.

Freud afirma ser a felicidade algo essencialmente subjetivo e conclui que cada sujeito só pode saber de sua própria felicidade ou infelicidade, mesmo que tentemos nos colocar no lugar dos outros ou avaliar o sentimento de satisfação para com a civilização.

Não pretendemos nos apressar nas nossas conclusões, pois pensamos ser importante entender primeiro o caminho de investigação que o próprio Freud teceu acerca do estado de civilização existente. Porém, parece-nos valiosa a contribuição de Birman (2005), com base na leitura de Freud, ao escrever que, após acreditar que seria possível o sujeito e o social viverem em harmonia, coloca isso em dúvida, verificando um desamparo do sujeito pelo novo campo social, que seria a modernidade. Destacou uma desarmonia, portanto, nos laços sociais que estavam se formando a partir desse novo modo moderno do homem viver a vida em comunidade: “[...] enfim, o discurso freudiano assume um estilo trágico de leitura da modernidade" (p.124).

\subsubsection{Civilização: viver em comunidade}

A palavra civilização poderia ser inicialmente descrita como a "soma integral das realizações e regulamentos que distinguem nossas vidas das de nossos antepassados animais" (FREUD, 1996, p.96) e produz com isso alguns aspectos singulares, são eles: reconhecermos como culturais todas as atividades e recursos uteis aos homens; tudo que é útil para ele está disponível e passível de ser conseguido; beleza, limpeza e ordem; estima e incentivo em relação às mais elevadas atividades mentais do homem e a maneira pela qual os relacionamentos são regulados. Esse seria o quadro geral da civilização, aspectos da vida humana que podem ser encarados como civilizados, sendo que, agora, o poder da comunidade 
substitui o poder individual e restringe suas satisfações, tornando-se um passo decisivo da civilização (FREUD, 1996, p.101). Ou seja, somente da vontade de um indivíduo não será possível reconhecer e aplicar essas restrições, porém, em comunidade, as leis se tornam necessárias.

Isso não quer dizer, alerta Freud, que civilização seja sinônimo de aperfeiçoamento. Talvez seja apenas uma forma que os homens encontraram para viverem juntos sem matar uns aos outros.

A partir da noção de civilização, Freud (1996) traça uma semelhança entre o processo civilizatório e o desenvolvimento libidinal, ou seja, que o desenvolvimento da civilização seria comparável à constituição do sujeito. Os instintos seriam "conduzidos a deslocar as condições de sua satisfação, a conduzi-las para outros caminhos.” (p. 103), esse processo coincidiria com o da sublimação dos instintos.

A sublimação do instinto constitui um aspecto particularmente evidente do desenvolvimento cultural; é ela que torna possível as atividades psíquicas superiores, científicas, artísticas ou ideológicas, o desempenho de um papel tão importante na vida civilizada. (p.103).

É interessante notar que, ao mesmo tempo que o autor enxerga o impedimento da satisfação completa que a civilização impõe, ao comparar este processo com o da maturação do sujeito, faz-nos ver que os dois são processos necessários, um chega a ser quase o outro, eles se confundem, pois o sujeito só se torna sujeito atravessado pela linguagem, pela civilização, no modo como ela funciona.

A sublimação do instinto seria para Freud a maior evidência da civilização ou o aspecto mais evidente do desenvolvimento cultural. A sublimação foi uma imposição da civilização aos instintos; esta seria construída sobre uma renúncia aos instintos, pressupõe a não-satisfação de instintos poderosos. Freud nomeia isso de frustração cultural, que é hegemônica nos relacionamentos sociais, entre os seres humanos, esta seria a causa da hostilidade para com a civilização.

Nesse sentido, como pode ser possível privar de satisfação um instinto? Essa perda deve ser economicamente compensada, pois nada simplesmente se perde no aparelho psíquico. Esta compensação se dará no trabalho e no amor, ainda que nunca totalmente, e é o que moverá o homem em sua vida em comunidade. (FREUD, 1996, p.104).

Freud observa que o homem primevo usava o trabalho para melhorar sua sorte, mas naquele momento isso dependia somente dele. É quando surge outro homem para dividir o trabalho que ele se dá conta do surgimento de um modo de convivência benéfico aos dois. 
Lembra o autor que em Totem e tabu, é da vontade arbitrária do pai que surge a vida comunal, no grupo de irmãos "Sobrepujando o pai, os filhos descobriram que uma combinação pode ser mais forte do que um indivíduo isolado" (FREUD, 1996, p.106)

Avida comunitária teria um fundamento duplo: a compulsão para o trabalho e o poder do amor (homem privando-se de seu objeto sexual, a mulher; e a mulher por sua vez, priva-se de seu filho). O primeiro resultado da civilização foi tornar possível que um número bastante grande de pessoas vivesse em comunidade. Sendo assim, presume Freud que seria cabível à comunidade continuar crescendo e progredindo sem problemas e desenvolvendo cada vez um maior e melhor controle sobre o mundo externo (FREUD, 1996, p.106), tudo isso com o intuito de tornar todos felizes.

\subsubsection{Amor, instinto e sexualidade na civilização}

Sobre o amor, como já apresentamos, Freud (1996) afirma que apenas uma pequena minoria consegue encontrar a felicidade no amor. O amor como busca da felicidade difere do que ele chama de tempestuoso, amor genital, que, por sua vez, confere incertezas e decepções. O amor que o autor descreve evita essas incertezas e se desvia do objetivo sexual para transformar "o instinto num impulso com uma finalidade inibida" (p.107). É inevitável - e Freud o faz - vincular esse amor à religião. Ou seja, essa aproximação com a religião é possível, pois seria uma forma de controlar e direcionar o instinto, essa seria sua finalidade inibida. Freud destaca a não distinção entre o ego e os objetos como característicos do amor disseminado pelas religiões.

Sendo assim, a "disposição para o amor universal pela humanidade e pelo mundo representa o ponto mais alto que o homem pode alcançar"(p.107), nos parece que Freud reconhece que esse tipo de amor pode trazer benefícios à civilização e ao trabalho, apesar de demonstrar objeções a essa sua afirmação. Essa frase do autor nos remete ao conceito de amor mundi cunhado por Hannah Arendt que "significa contribuir para que o conjunto de instituições políticas e leis que nos foram legados não seja continuamente transformado ou destruído ao sabor das circunstâncias e dos interesses privados e imediatos de alguns poucos" (CÉSAR; DUARTE, 2010, p. 826). Apesar de beberem em fontes diferentes quanto a suas áreas de conhecimento, um da Filosofia outro da Psicanálise, encontramos algumas aproximações se pensarmos que os dois estão tecendo uma crítica ao modo de vida moderno. Esse cuidado com o mundo, sobre o qual Arendt alerta, pode ser refletido no pensamento de Freud, sob nossa ótica e reflexão, como uma das formas do homem lidar com as pressões das 
leis impostas pela sociedade, pois não podemos simplesmente nos livrar delas sempre que as acharmos descabidas.

Freud nota uma incompatibilidade inevitável entre amor e civilização, de um lado o amor vai ao encontro de alguns interesses da civilização; do outro lado esta, com suas restrições, ameaça o amor. Tal antagonismo deve-se à tendência da civilização em restringir a vida sexual, que caminha nessas duas direções. Outros nomes para o resultado desse embate entre amor e civilização seriam os tabus, as leis e os costumes que trazem outras restrições influenciando a todos. (FREUD, 1996, p.108-109).

A civilização como Freud descreveu naquela época, permitia relacionamentos sexuais entre um só homem e uma só mulher e tolerava isso somente porque até o momento não haveria algo que substituísse. Sob esses limites, dados pela civilização, a vida sexual do homem civilizado se encontraria prejudicada. Considerando a civilização como antagônica à sexualidade.

Apesar de Freud (1996) considerar que boa parte da razão do sofrimento do homem centra-se no funcionamento da civilização, observa que "somos levados a pensar que não se trata apenas da pressão da civilização, mas de algo da natureza da própria função que nos nega satisfação completa e nos incita a outros caminhos" (p.110-111). Freud parece até hesitar nessa afirmação: "Isso pode estar errado; é difícil decidir" (p.111), mas podemos concordar com ele se pensarmos no sentido da falta fundante do sujeito, o "furo", aquilo que nunca será satisfeito por completo e que sempre estimulará o homem a procurar por outros caminhos. A própria instauração do sujeito do desejo, aquele que é barrado pela cultura e empurrado a seguir em frente.

\subsubsection{Agressividade}

A agressividade estaria presente em todos, seria o fator que perturba nossos relacionamentos com o próximo, representando uma ameaça de desintegração da sociedade pela não convivência entre os homens. $\mathrm{O}$ " [...] temor a uma revolta por parte dos elementos oprimidos conduz à utilização de precauções mais estritas.” (FREUD,1996, p.109).

Freud destaca uma máxima conhecida pelo cristianismo ao falar sobre o amor e a agressividade nascentes no homem civilizado: “Amarás a teu próximo como a ti mesmo", discordando veementemente desta, já que, há sim, no homem, uma poderosa cota de agressividade, não acreditando que sejam apenas criaturas gentis sedentas por amor, mesmo que vistam este semblante. (p.116). 
Tais apontamentos remetem inevitavelmente ao que refletimos em nossa introdução acerca da visão romântica da Educação e a visão idealizada da criança e do trabalho do professor, pois o que Freud salienta é que essa máxima vai contra a natureza original do homem, ou seja, não pode ser que consiga viver em comunidade apenas por amar a seu próximo, deve, sim, ajustar essas relações. Portanto, crer que todos se amarão e viverão em harmonia passa a ser um pensamento utópico.

Sendo a agressividade uma realidade da natureza humana, a civilização estabelece limites para esses instintos agressivos, este seria um dos fatores que perturbaria nossos relacionamentos. Por isso, a sociedade civilizada se vê ameaçada de desintegração, pois algumas vezes não consegue controlar esses instintos. "A civilização tem de utilizar esforços supremos a fim de estabelecer limites para os instintos agressivos do homem[...]" (FREUD, 1996, p.117).

Os métodos para estabelecer limites seriam: o incentivo a relacionamentos amorosos inibidos (amizade), restrições à vida sexual e amar ao próximo como a si mesmo. É de se esperar que não se consiga muito com esses incentivos, pois "a lei não é capaz de deitar mão sobre as manifestações mais cautelosas e refinadas da agressividade humana" (FREUD, 1996, p.117). Agressividade pode ser entendida como as formas de manifestações "instintivas", aquelas que não são possíveis de serem controladas pelas leis e incentivos civilizadores. Algo sempre resta apesar do controle da civilização.

Sobre o controle da sociedade, Freud (1996) dá o exemplo dos comunistas, que acreditam que o homem é bom, mas a instituição da propriedade privada corrompeu sua natureza boa, logo, uma vez abolida a propriedade privada, toda essa inclinação do homem à agressividade estaria solucionada. "A propriedade da riqueza privada confere poder ao indivíduo e, com ele, a tentação de maltratar o próximo [...]” (p.117), porém Freud alerta que "abolindo a propriedade privada, privamos o amor humano da agressão de um de seus instrumentos [...]" e ainda lembra que a agressividade já existia desde os tempos primitivos, portanto não poderia ter surgido com a propriedade privada.

Freud critica veementemente esta visão como sendo uma "ilusão insustentável" (p.118), dizendo que a agressividade não foi criada pela propriedade privada, pois esta reina desde os tempos primitivos, quando havia muito pouco dela. Poderíamos concluir que Freud estaria pensando a agressividade do homem como de sua natureza, criada talvez pela civilização, pois só é possível na convivência de uns com os outros. Ele diz ainda que a agressividade "constitui a base de toda relação de afeto e amor entre pessoas" (p118) "se a civilização impõe sacrifícios tão grandes, não apenas à sexualidade do homem, mas também a 
sua agressividade, podemos compreender melhor porque lhe é difícil ser feliz nessa civilização" (p.119).

Ao contrário do homem primitivo, que não tinha restrições ao instinto - contudo não desfrutava dessa liberdade instintiva (apenas seu chefe o podia) - o homem civilizado "trocou uma parcela de suas possibilidades de felicidade por uma parcela de segurança” (FREUD, 1996, p.119)

Freud vê com bons olhos a crítica ao estado da civilização atual, como sendo o exercício de um direito justo dos que fazem parte dela e não como ataques inimigos à civilização. Acredita também que poderia haver, futuramente, alterações na civilização que contribuiriam para satisfazer melhor as necessidades dos que vivem nela.

O autor pondera, por outro lado, a possibilidade de se "familiarizar com a ideia de existirem dificuldades, ligadas a natureza da civilização, que não se submeterão a qualquer tentativa de reforma” (p.120). Esse trecho é muito importante para pensarmos o mal-estar estrutural na civilização, que, como concluímos baseados em Freud, é impossível não existir na convivência entre os homens, ou seja, está intrínseco a nossa forma de vida.

Ao afirmarmos que o mal-estar é estrutural, não estamos chancelando que não há espaço para o variável. É preciso perceber que as circunstâncias e a causalidade sempre terão espaço apesar da estrutura do mal-estar. É este motivo que faz o estudo de Freud permanecer sempre vivo e atual.

Freud chama-nos a atenção nesse momento para o perigo iminente de um estado de pobreza psicológica dos grupos. Esse estado seria a consequência de uma sociedade na qual os vínculos se comporiam pelas identificações dos sujeitos uns com os outros, deixando de lado a importância ou o destaque do líder na comunidade, ou seja, esse vai perdendo espaço dentro do grupo (p.120).

É possível compararmos este perigo alertado por Freud com a perda da autoridade na civilização moderna, quando um líder não tem mais importância frente ao grupo ou quando a tradição já não sustenta mais uma ordem sobre a qual podemos falar em nome de. Esses ajustes e alterações na civilização que o autor apresenta como possíveis de nos tornar mais felizes nesse ambiente, teria também seu outro lado, o perigo do estado de pobreza psicológica dos grupos, o que a nosso ver seria a crise pontual moderna vivida a partir do malestar estrutural da civilização.

Freud adianta parte do que vemos acontecer hoje em sua noção de estado de pobreza psicológica dos grupos. A nosso ver, essa hipótese é completamente cabível no modo de funcionar hoje o laço social contemporâneo, sendo, sob esta visão, o declínio da autoridade o 
ponto de partida das mudanças causadas pela modernidade. Esse estado nada mais é do que o resultado do modo de operar que a modernidade inaugurou, ou seja, não havendo mais líder ou autoridade com atestada importância na formação do grupo, os vínculos são feitos apenas pelas identificações de uns com outros, igualando os pesos tanto de suas opiniões quanto de seus poderes na sociedade. Tal movimento acometeu também os professores e, por consequência, a Educação e é sobre isso que iremos tratar no subcapítulo seguinte.

Ainda desenvolvendo a ideia de Freud, parece-nos que a modernidade tardia inaugurou o "sem limites", mas o que isso pode significar, já que, segundo Freud, é isso que buscamos em nossa miserável condição humana. Será essa liberdade sem limites que nos aproximará da felicidade?

Alain Touraine (1998) embarca nos questionamentos da empreitada moderna em seu livro Poderemos viver juntos? no qual, logo no início, já nos dá como resposta que, sim, já vivemos juntos “[...] bilhões de indivíduos veem os mesmos programas de televisão, bebem as mesmas bebidas, usam as mesmas roupas e, para se comunicar de um país a outro, usam também a mesma língua." (p.9). Porém, segundo ele, isso não seria suficiente para afirmar que pertencemos a uma mesma sociedade ou cultura, pois a própria globalização por estar presente em todas as partes não pertence a lugar nenhum. Estaríamos nós pertencendo e construindo um mundo utópico, do qual acreditamos estar cada vez mais próximos e com isso nos distanciando cada vez mais em relações artificiais?

Touraine (1998) aponta para uma dessocialização na cultura de massa que "[...]faz com que vivamos juntos apenas à medida que fazemos os mesmos gestos e utilizamos os mesmos objetos, mas sem sermos capazes de nos comunicar além da troca dos signos da modernidade" (p.10). Segundo ele, ocorre, na contemporaneidade, um funcionamento inverso ao do século passado, durante a industrialização do mundo ocidental. Naquela época, as comunidades, fechadas em sua identidade global, estavam evoluindo para sociedades nas quais as funções entre os sujeitos se diferenciavam e se racionalizavam. Nesse ponto, corrobora com Freud, que afirma que a evolução da vida em sociedade seria pautada por um controle cada vez maior do mundo externo pelos próprios sujeitos, indicando, no entanto, que a vida moderna seria muito mais complexa. Hoje essa evolução é praticamente inversa, diz Touraine. Cada vez mais vemos grupos e associações que se juntam para restringir aqueles que querem viver sob uma mesma crença. "[...]as sociedades voltam a ser comunidades reunindo estreitamente, num mesmo território, a sociedade, a cultura e o poder sob uma autoridade religiosa cultural, étnica ou política[...]" (1998, p.10-11). 
Nesse funcionamento, assistimos a um apelo à igualdade, ou seja, um incentivo para que todos vivam juntos e iguais. $\mathrm{O}$ autor alerta para a falsa sensação de que a globalização beneficia um mundo unido, o que nos faz mais uma vez conversar com Freud, considerando que ele já alertava para a ineficácia da máxima "Amarás a teu próximo como a ti mesmo", como uma tentativa de aproximar os sujeitos. Touraine (1998) reforça: "[...]quanto mais uma mensagem é transmitida massivamente, e sem ligação com o social, menos ela modifica comportamentos" (p.11).

Tendo esse cenário em mente, partiremos para a formação de um panorama da crise na Educação, continuando a desvendar as vicissitudes da vida moderna e seus sujeitos.

\subsection{CRISE NA EDUCAÇÃO À LUZ DO PENSAMENTO DE HANNAH ARENDT}

No discurso do senso comum, tudo aquilo que está em crise deve ser colocado em ordem. Sendo assim, a crise na Educação é falada e considerada como um mal a ser exterminado, uma etapa a ser superada, chegando a conclusões do tipo: “[...] a escola e a Educação estão em crise porque algo a elas lhes falta e cujo agenciamento na sua dose certa seria o passaporte para uma Educação e uma escola já não mais em crise - seja o que ela for" (LAJONQUIÈRE, 2012) ${ }^{5}$.

As técnicas e propostas para tal superação se expandem e buscam soluções em todas as áreas. Isso posto, pretendemos abordar o tema, traçando um panorama da crise, a partir do mal-estar na civilização, com o objetivo de discutir e agrupar ideias sobre a crise pontual na Educação e, dessa forma, tratar da impossibilidade de prever e calibrar a intenção educativa no miolo da diferença geracional, ou seja, na lacuna entre o passado e o futuro.

Muitos artigos, teses e dissertações recentes abordam o ensaio de Hannah Arendt em direções diversas, sendo já considerado material de referência para a área da Educação. Em sua maioria destacam efetivamente a presença da revolução pedagógica e das novas teorias como emblemáticas da crise. São alguns exemplos:

Os problemas na área da Educação começaram a aparecer como fruto da ilusão de um novo mundo que realmente se constitui com a Revolução Americana, mas que só era novo em relação ao que havia no restante do mundo. Mas essa ilusão só veio a se tornar um problema político a partir do século $\mathrm{XX}$, com o advento de novas teorias pedagógicas que pretendiam revolucionar a Educação, partindo da rejeição de tudo que era considerado tradicional. (DEINA, 2012, p.85).

\footnotetext{
${ }^{5}$ Sem numeração de páginas
} 
Em vez de se estabelecer enquanto lugar fundamental de formação e preparação de jovens e crianças para o mundo público dos adultos, o campo educacional viu surgir métodos pedagógicos e psicológicos centrados na criança e no adolescente, os quais, ao serem entendidos como substratos psíquicos naturais, não históricos, viram-se alienados do mundo que habitam e que precisam conhecer para poderem futuramente preservá-lo e transformá-lo. (CÉSAR; DUARTE, 2010, p.830).

Hannah Arendt colocou a temática da crise que afeta a educação em foco no livro intitulado Entre o passado e o futuro, lançado nos Estados Unidos em 1957 e publicado pela primeira vez no Brasil em 1972. Nessa compilação, a autora inseriu um ensaio especialmente para tratar do tema da Educação, Crise na Educação, o qual nos será de interesse, juntamente com outros autores que dedicaram alguns momentos em suas obras para discutir a Educação na contemporaneidade, mesmo não estando diretamente ligados à área. Tal fato dá indícios do quanto o tema abrange reflexões em todos os aspectos.

Podemos dividir o texto de Arendt em dois principais momentos. Um, irá tratar com maior ênfase das causas, problemas e consequências da crise periódica na Educação, que se deu na América. Em outro momento, podemos perceber que discussões mais gerais sobre práticas na Educação e reflexões sobre o mundo público e privado serão abordadas.

A autora mostra bastante peculiaridade quanto à crise da Educação na América que que se espalhou pelo mundo. A grande discussão que ela irá encaminhar nesse sentido, tratase da Educação na América naquele dado momento, pois, nas escolas americanas, lida-se com um fator importante, a imigração, que pode modificar todo um percurso de ensino, pois requer medidas específicas. Naquelas escolas, portanto, o trabalho a ser feito - tanto com os filhos quanto com os pais - incluía não somente a introdução a um "mundo novo", mas também desfazer-se de um "mundo antigo". A autora partirá dessa situação específica na América para refletir e discutir sobre a Educação contemporânea e a consequente crise que acometeu o mundo.

É realmente uma ilusão de que estaria sendo criado um mundo novo a partir da Educação das crianças. A autora deixa claro que há a necessidade americana de acabar com um Velho Mundo e fazer fundar uma nova ordem, um Novo Mundo, sendo essa possibilidade a propulsora da crise em outros países e setores. É preciso lembrar que o mundo no qual a criança está sendo introduzida já está construído, já existe e não será possível apagar todo esse passado para que seja construído o novo.

A crise delineada por Arendt (2013) não é vista como uma catástrofe ou um beco sem saída, como muitas vezes vemos aparecer aqui e ali, mas sim, um momento de rever paradigmas, de fazer novas perguntas e formular respostas velhas ou novas e de enfrentar 
novas possibilidades no laço social. Carvalho (2011) um estudioso dos escritos arendtianos, mostra essa singular posição da crise descrita pela autora:

Assim, se o termo "crise" nos remete a ideia de um tempo de incertezas e perigos, também sugere a noção de um "tempo decisivo"; o momento que exige discernimento e intervenção. Não se trata, pois, necessariamente do prenúncio de um desastre ou de um processo agudo de degeneração. (p.19).

A autora pontua, primeiramente, uma crise geral do mundo moderno e destaca como mais característica a que virá a afetar a Educação. A crise geral teria afetado o mundo moderno em toda parte, já a tensão que se deu na Educação teria sido mais relevante na América, tomando proporções gigantescas, ao longo dos anos, para se tornar preocupação número um para a sociedade, como um problema político (p. 221).

Segundo Arendt (2013), a crise na Educação tornou-se um problema político quando as instâncias de autoridade passaram a se preocupar com isso e detectaram, no declínio do sistema escolar, perigos iminentes para a sociedade - especialmente em uma terra de imigrantes onde a tarefa de ensinar o idioma aos recém-chegados é desenvolvida no âmbito escolar e não tanto no lar como seria natural.

Mesmo sendo um problema político, é difícil não considerar a crise somente um fenômeno das instituições escolares e dar-lhe as devidas proporções, pois como podemos inferir, a crise é muito mais abrangente do que aparenta, ou seja, não se trata apenas da precariedade dos fins da Educação, por exemplo, o fato de que muitas crianças saem das escolas analfabetas ou deixam de concluir a Educação básica. Trata-se, sim, do impasse entre os adultos e as crianças, da diferença geracional, da lacuna entre o passado e o futuro. Voltaremos a este ponto mais adiante, por hora, continuemos a entender a crise na Educação segundo Arendt.

A crise oferece a oportunidade de repensar preconceitos, conceitos já estabelecidos que costumavam dar respostas às questões, faziam parte daquilo que Arendt chama de senso comum e, muitas vezes, as respostas eram simplesmente seguidas como sendo o caminho certo. É por esse motivo que a reflexão sobre a crise toma um papel essencial para não se tornar apenas um pretexto para todos os problemas - no caso, da Educação - serem postos a nu e tratados como um vazio a ser preenchido para que a Educação assim passe a funcionar perfeitamente, ou seja, preencher esse vazio com o que estaria faltando no nosso modo de educar "tão atrasado" ou que "não acompanhou a evolução das tecnologias" ou ainda "tradicional”, frases que ouvimos repetidas vezes no discurso atual sobre a Educação contemporânea que precisa de soluções "modernas". 
Arendt destaca que o desaparecimento do senso comum seria o sinal mais alarmante da crise. Carvalho (2011) explica que no contexto arendtiano a perda do senso comum não se remete à "acepção corrente de oposição a um saber científico, mas como ausência de significações partilhadas por uma comunidade" (p.19). O risco encontra-se ao ser a crise encarada como um momento de colocar tudo o que se acreditava antes dela sob suspeita, pois, ao estabelecer que todas as condutas na Educação estiveram erradas até hoje, não há margem para o reinício, tendo em vista que o principal objetivo da crise é continuar a oferecer a oportunidade aos novos de continuar neste mundo vivendo em sociedade sem nos matarmos uns aos outros, como inferimos a partir de Freud.

Há também outro ponto para refletir acerca do senso comum ao estabelecermos uma relação com as ideias de Touraine (1998). O senso comum constituiria significações partilhadas por uma comunidade, na qual a utópica sensação de vivermos juntos vem da ideia de podermos compartilhar significações semelhantes, partilhadas com todos. Arendt estava certa nesse aspecto. Perdemos o senso comum, mas a questão gira em torno do desafio de continuarmos vivendo juntos, sem que para isso precisemos desse senso comum.

Não estamos, com isso, subestimando a possibilidade de que a Educação e a escola possam ser repensadas ou negando que haja, sim, problemas com a Educação hoje. Pelo contrário, essa é a razão de nossa pesquisa.

A crise, pensada como problema a ser sanado, não permite pensar que ela pode ser a própria solução, propiciando reflexões para dar espaço ao novo. No momento em que tudo, todo o "juízo humano" e todas as respostas estão sob suspeita, sinaliza-se uma crise da Educação, que, nesses termos, só se torna um engodo cada vez maior. Em outras palavras, o conflito que gera a crise se transforma em soluções práticas, por exemplo, as novas metodologias nas escolas ou a prática pedagógica da autonomia, em vez de ser pensada - a crise - como pontual em uma sociedade que deseja dar continuidade a sua humanidade. Assim como inferimos de Freud, o mal-estar na civilização ou na cultura é o modo de operar - estrutural - do homem moderno, sendo assim, pensar sobre a crise e os sintomas que surgem dela ou, mais ainda, refletir sobre o sujeito que se molda a esse contexto, sem com isso entregar a solução em fórmulas, faz-se importante para não cairmos no engodo a todo tempo presente do iminente declínio do sujeito e da sociedade.

Dessa forma, a crise não pode deixar de acontecer em uma sociedade que deseje continuar crescendo e sendo humana. Este é seu fator estrutural: dar oportunidade para que os novos continuem o que já foi feito e possam introduzir algo novo e isso acontece sempre que um ser humano nasce. Seu nascimento gera uma nova crise. A própria entrada do novo ocorre 
como uma ameaça à continuidade do mundo, caso os velhos não o protejam contra os novos. Isto quer dizer que os aqui já chegados têm a obrigação de apresentar o mundo aos novos, o que já foi feito até aqui, até hoje e, assim, proteger o mundo para que não acabe em ruínas.

Arendt afirma que, em meados de 1920, todas as tradições e métodos de ensino foram negados de uma hora para a outra na América e critica o fato de que, ao se deparar com novas teorias e novas possibilidades, "todas as regras do juízo humano foram postas de parte" (p.227). Ela ainda destaca que essas novas teorias da Pedagogia foram aceitas indiscriminadamente, fato que vemos acontecer especialmente hoje em muitos lugares e destacadamente no Brasil, como uma nova tendência no campo da Pedagogia.

Vamos entender o ponto chave da discussão em torno não só de uma crise na Educação, mas sim, da própria Educação como fator estrutural, que, por sua vez, vai além da situação política americana que Arendt sublinha e que permite discutir a crise na Educação.

O ponto essencial para uma discussão acerca da Educação, reside no fato de que, para Arendt, a essência da Educação é a natalidade, ou seja, pessoas nascem todos os dias aqui e, por esse motivo, a própria natalidade é o que nos dá oportunidade, ou até obrigação, de continuar o mundo, fazendo com que a Educação continue a ter uma função inevitável: introduzir os novos ao mundo velho. Carvalho (2011) nos explica que o termo natalidade para Arendt é diferente do termo nascimento. O nascimento seria a forma pela qual a vida pode se renovar, quando surge um novo ser na vida; já a natalidade indicaria não apenas um novo ser na vida, mas um novo ser humano no mundo, que é um "[...] complexo conjunto de tradições históricas e realizações materiais e simbólicas[...]” (p.19).

Se, numa situação utópica, os bebês nascessem já inteirados de como viver no mundo ao qual chegam ou se tivéssemos chegado todos de uma só vez - como também discute Batista (2012) - a Educação perderia sua função, não haveria conhecimento a ser passado, tampouco haveria possibilidade de novas formas de ver o mundo o qual habitamos e muito menos haveria transmissão de uma geração para outra. Portanto, a não ser que crianças parem de nascer, a essência de uma sociedade que funciona permeada por um discurso será sempre a Educação - não somente da instituição escolar, mas sim do fato de que o encontro de um adulto com uma criança gera inevitavelmente o propósito de educar. Batista(2012) chega a concluir que “[...] se pertencêssemos todos a apenas uma mesma e única geração, então, por certo, a Educação seria aí completamente dispensável.” (p.15).

O fato de existir um mundo comum a todos nós, nos dá indícios da função que o velho, que está aqui há mais tempo, teria para com esse novo que acaba de chegar. Além disso, evidencia que, apesar de pertencermos todos a um mundo comum, estamos marcados 
pela diferença geracional, em outras palavras, haverá sempre alguém mais velho para "dar as boas-vindas" àquele que acaba de chegar.

Arendt esclarece que, um país no qual a democracia igualitária rege todo o temperamento político, tem como meta o princípio de igualdade e sendo assim, se esforça para igualar as diferenças entre o velho e o novo ou até para apagá-las. Essa tentativa de igualar fica muito clara quando pensamos em exemplos cotidianos do discurso majoritário da Pedagogia, por exemplo, a inserção de crianças com necessidades especiais em salas comuns da Educação pública obrigatória, a mudança da posição do professor como "detentor" do conhecimento para aquele que também aprende - um mediador - a inserção de um currículo comum para todos etc.

Essas medidas tornam evidente a tentativa de apagamento das diferenças, tanto entre os novos, quanto entre velho e novo e também entre quem tem o poder e quem é conduzido. A mudança da posição do discurso do professor parece ser uma das mais representativas a respeito do que estamos discutindo.

\subsubsection{Os três pressupostos básicos da crise}

Arendt (2013) apresenta três pressupostos básicos como alguns dos motivos da crise na América. O primeiro pressuposto consiste na separação da criança do mundo adulto e sua imersão total de relações no mundo que é seu, o das crianças. O segundo pressuposto nos diz que o professor não precisaria mais conhecer sua disciplina, mas entender de ensino, ou seja, como ensinar crianças - nesse ponto é apresentado um questionamento da função e da formação do professor. O terceiro seria a substituição da aprendizagem pelo fazer e do trabalho pelo brincar, visando apenas ao desenvolvimento de habilidades, ou poderíamos dizer, a transformação da escola em um funcionamento no estilo de produção, visto que propor-se-ia a conhecer cada vez melhor seu objeto (aluno) e fabricar sua melhor posição na sociedade funcionando como um mercado de saber.

O primeiro pressuposto, portanto, gira em torno da crença que se tornou hegemônica de que existe um mundo da criança e os adultos apenas dariam assistência para um "governo entre crianças"; ou seja, "[...]uma sociedade formada entre crianças, autônomos e que se deve, na medida do possível, permitir que elas governem." (ARENDT, 2013, p.229-230).

Esse pressuposto retoma a premissa de que os mais velhos creditam nos recémchegados a possibilidade de mudança daquilo que não vai bem, pois como lembra Batista (2012) “[...]a criança é recebida assimetricamente no mundo” (p.17). Sabemos que ver nos 
mais novos essa possibilidade é de fato um fator estrutural inerente à natalidade, ou seja, é um comportamento comum a nós humanos, mas a diferença que vemos aí, neste primeiro pressuposto de Arendt, é que os adultos se retiram da posição de educar, de apresentar o mundo aos que chegam. $\mathrm{O}$ adulto se vê impotente frente à criança e, com isso, a tarefa de educar fica somente entre as crianças, entregues a si mesmas. Segundo essa visão, arriscaríamos supor que a palavra dos adultos passa a não ter mais peso, não faz mais efeito.

Supondo que é de fato impossível que as crianças se humanizem por si (BATISTA, 2012, p. 16), o que entendemos da visão de Arendt é que os adultos não se autorizam em sua fala como aqueles que têm algumas respostas sobre o mundo, com o receio de não influenciar os mais novos na criação de um novo mundo, uma nova ordem, e não atrapalhar o novo governo de crianças, ou seja, supostamente essa palavra endereçada aos mais novos, a própria transmissão, supõe a priori um saber contido nas crianças e não mais nos adultos. Assim, para Arendt, a tarefa não seria de criar o novo, mas sim permitir que cada geração se transforme em um mundo antigo. (p.226).

Há uma diferença estrutural - a diferença geracional - entre os que já estão aqui e os que estão chegando e muitas vezes, principalmente frente a uma crise, na qual paradigmas são alvo de revisões, é dada maior importância aos recém-chegados, o que talvez se deva à ilusão de deixar para trás alguns fantasmas que povoam todas as razões de uma crise.

Ainda sobre o primeiro pressuposto apresentado por Arendt, podemos dizer que, ao mesmo tempo em que é depositada nas crianças a ilusão da criação de um mundo melhor e, assim, são deixadas por si mesmas, os adultos retiram-se sorrateiramente da função de mostrar o mundo para as crianças, vestindo o disfarce de um mundo melhor ou uma Educação libertadora. Seria como se os adultos não quisessem mais se responsabilizar pelo andamento do mundo e entregassem esse fardo às crianças, para que resolvam entre elas, já que possivelmente estes adultos acreditam que o que foi feito até hoje já não serve mais ou está atrasado se comparado ao quanto as crianças de hoje nascem espertas, inteligentes e avançadas.

Sobre isso, Arendt resumiu: “o que quer que o mundo adulto possa propor de novo é necessariamente mais velho do que eles mesmos.” (2013, p. 226) Ou seja, a própria missão dos adultos de criar um novo mundo (a partir dos que chegam), uma nova ordem, já está de início fracassada, pois isso tem de ser proposto pelos mais novos - não é possível dar o novo ao novo. Batista enriquece a discussão nos questionando: 
Poderíamos admitir que haveria pertinência em se permitir que as crianças em nome da suposta supressão da diferença (dita opressiva) entre gerações se educassem sozinhas (sic)? Seria o caso de já não lhes transmitir mais nada, a fim de que elas desenvolvessem apenas o que lhes é suposto como "autêntico", posto que interior, natural e pré-formado? (2012, p.17).

A tal supressão da diferença entre gerações faz mais uma vez lembrar que se trata da retirada da responsabilização do velho pelo novo no mundo e do velho pelo próprio mundo. Faz parte também da necessidade de diminuir a lacuna entre velhos e novos, entre passado e futuro, em nome da igualdade.

Outro princípio que anda lado a lado com a igualdade e que Arendt também discute é a liberdade, dizendo ainda sobre o primeiro pressuposto que "[...] ao emancipar-se da autoridade dos adultos, a criança não foi libertada, e sim sujeita a uma autoridade muito mais terrível e verdadeiramente tirânica, que é a tirania da maioria.” (p.230) Essa constatação fica muito clara quando, por exemplo, os professores propõem para todos os alunos da turma que decidam em conjunto como deverá ser a punição de um amigo que desobedeceu as regras de sala - é evidente o quanto as crianças não são nem um pouco compassíveis com o outro, impondo punições severas e agindo com tirania frente ao outro, caso não haja um adulto para delimitar tal situação

Para exemplificar o viés libertário que atingiu o pensamento educacional do século, consideramos importante lembrar que, após a influência das ideias de Rousseau na Educação, um grande expoente da Educação libertária foi A. S. Neill, autor de, entre outros livros, Liberdade sem medo (1980) e idealizador da escola Summerhill (fundada em 1921) na qual a proposta era deixar que as crianças decidissem o que queriam estudar e se sentissem, acima de tudo, livres e sem medo dos adultos.

A breve leitura de seus relatos sobre Summerhill já nos confirma a presença de um ideal capaz de criar ou estabelecer um "mundo da criança" para separá-lo do "mundo do adulto". Nesse caso, nos perguntamos se não seria ela, a própria escola, uma das que têm a função de mostrar como se organiza o mundo (como crianças e adultos vivem juntos) e não de reproduzir o mundo, já que "[...] a complexidade do mundo público e os conflitos que o marcam não são reprodutíveis no âmbito escolar e, se o fossem em sua plenitude, a escola já não teria sentido [...]" (CARVALHO, 2013b, p.38).

Neill (1980) descreve Summerhill como uma escola moderna e tem em seu objetivo principal propor uma adaptação da escola à criança e não o contrário como lhe parecem ser as escolas "não modernas". Relata no livro a existência de um menino que sempre ia a sua sala perguntar o que deveria fazer; Neill sempre respondia que ninguém lhe diria o que fazer 
(p.29) e afirmava que, após algum tempo, as crianças conseguiam tomar decisões próprias. Vemos aí o mundo da criança aparecer mais uma vez, deixado à mercê de suas próprias decisões, sem a interferência do adulto, o que nos parece desresponsabilizar os mais velhos do curso das coisas.

É natural que, com o nascimento de crianças, a crença de renovação apareça, ou seja, é estrutural depositar ilusões naquilo que nós, os velhos, não conseguimos cumprir do jeito que achávamos que deveria ser, ou ainda, “[...] em se tratando de crianças, o assunto diz respeito inexoravelmente a nossos sonhos, medos e esperanças relativos ao mundo do amanhã" (LAJONQUIÈRE, 2010, p. 36). É assim que o mundo se renova. Porém, pretendemos ressaltar com esse desmembramento da crise que talvez seja preciso entender que tampar o furo da crise é tão impossível quanto a Educação o é. Não há Educação que esteja no ponto para todos e este movimento de impedir o furo acaba por tomar uma forma sintomática na Pedagogia.

Quando dizemos que a Educação é impossível estamos nos referindo mais uma vez às enunciações $^{6}$ de Freud sobre as profissões impossíveis. É onde encontramos o impossível de educar que a Pedagogia não mede esforços para que o ato de educar se torne "possível”, ou seja, que os resultados obtidos possam ser previstos segundo uma metodologia bem aplicada.

Carvalho (2013b) ajuda-nos a entender essas mudanças - causas prováveis da crise na Educação, que, ao passo que quer exterminar seu caráter impossível, a torna cada vez mais não realizada. $\mathrm{O}$ autor descreve que, ao longo do século $\mathrm{XX}$, diferentes teóricos da Educação tenderam para um único caminho: “[...]vincularam substancialmente o sentido da ação educativa ao cultivo de um compromisso com a liberdade" (p.27), ou seja, a proposta seria assegurar que a Educação aconteça de forma "suave", prazerosa e libertadora, à medida que entrega ao aluno a responsabilidade pelos seus atos e à escola a responsabilidade de se adequar a ele, aluno. Julgamos que deve haver uma troca entre aluno e escola - não deve a escola se adequar ao aluno, tampouco o aluno se adequar a escola. No mais, as correntes pedagógicas tentam tornar este encaixe possível ao conceber métodos para desenvolver a liberdade, considerando-a característica em estado germinal no indivíduo, necessitando ser estimulada.

O segundo pressuposto ou medida que precipitou a crise, de acordo com Arendt, discute também este caminho que estamos desenvolvendo, pois recai na influência da Psicologia sobre as novas teorias da Pedagogia. "Sob a influência da Psicologia moderna e

\footnotetext{
${ }^{6}$ Prefácio ao livro de A. Aichorn(1925) e em Análise terminável e interminável (1937).
} 
dos princípios do Pragmatismo, a Pedagogia transformou-se em uma ciência do ensino em geral a ponto de se emancipar inteiramente da matéria efetiva a ser ensinada" (ARENDT, 2013, p.231).

Procurando renovar sua fé no ensino, a Pedagogia deixou-se influenciar pelas diversas correntes nascidas na Psicologia que prometiam encontrar o modo ideal de equilibrar a relação ensino-aprendizagem. Dessa forma, o objetivo educacional passa a estar centrado mais no ensino geral e na própria aprendizagem (como a criança aprende e como se deve ensinar) do que no conteúdo das matérias em si. As teorias modernas acerca da aprendizagem tomam conta da prática e do discurso escolar, sendo um discurso comum das escolas modernas que pensam a criança como centro da relação ensino-aprendizagem. Lajonquière (2010) retoma resumidamente o caminho para chegar a essa aceitação das novas teorias da Pedagogia.

A partir da virada do século XVIII para o XIX, o saber pedagógico,
entrelaçado com a nascente psiquiatria e a filosofia do Iluminismo, adquiriu
uma fisionomia tal que se tornou paradigma para as gerações futuras de
"especialistas na Educação e reeducação de crianças". Saber positivista, que,
convertido em ideologia hegemônica no campo pedagógico, expande-se
mascarado com o véu da naturalidade dando assim, lugar ao discurso
(psico)pedagógico hegemônico." (p.122).

Nesse trecho, Lajonquière relembra sua tese de 1999 sobre a tomada das escolas pelo discurso (psico)pedagógico hegemônico. "Psico" entre parênteses é a forma utilizada para descrever um discurso hegemônico da pedagogia que está atravessado pelas ilusões dos saberes "psi”. Esse discurso consiste em uma busca incessante pautada nas psicologias comportamentais e estudos na área da neurologia pelo método ideal de Educação, assim como sustenta que a escola dita tradicional não evoluiu junto com as crianças de hoje e se tornou defasada, precisando da psicologia para entender como funciona a relação ensinoaprendizagem. Defendendo, assim, que existe na criança uma maneira natural de aprender.

Ao criar um mundo da criança e emancipá-lo do mundo adulto, o tempo de infância sem a influência dos adultos, que visa a deixar-lhes criar livremente seus destinos, hoje fica um tanto perdido, pois o que é a infância, senão as próprias ilusões do mundo adulto e seus fantasmas investidos na criança? O tempo de infância por si só não é possível existir, ele é inventado e reinventado no encontro do velho com o novo.

Ao refletirmos sobre a experiência de Neill relatada acima, poderíamos dizer que a ilusão a ser depositada nas crianças era de um mundo livre das exigências adultas, sendo assim, chega a ser plausível a vontade de Neill, já que segundo ele a escola em outros tempos 
representava a humilhação dos alunos e a punição física e moral. Para o autor, esse novo modo de educar daria oportunidade para as crianças de criar seu próprio mundo.

A questão aqui é que neste momento da história, tanto da modernidade quanto da Educação lutava-se contra as amarras, por exemplo do autoritarismo, da humilhação moral. Amarras analisadas inclusive por Freud ao serem consideradas nocivas ao sujeito que se formava. No entanto, como viemos desenvolvendo, algumas dessas amarras já foram amenizadas, incluindo a da autoridade - a qual a própria autora diz não existir, porém ao que nos parece é que as escolas de hoje ainda lutam contra um mundo que não existe mais, um mundo cruel e autoritário com as crianças, no qual seria obrigatória a presença da Psicologia para nos ajudar a entendê-los cada vez melhor.

Em outras palavras, qualquer ação educativa passaria hoje pelo crivo psicológico acerca de sua pertinência, tanto no âmbito escolar quanto no âmbito privado das famílias, que ao render-se à psicologização da Educação apela aos manuais de como educar seu filho. A nosso ver, esse movimento tira de cena a possibilidade de funcionar o saber não sabido, aquele que diz algo sobre o desejo, que ao mesmo tempo em que deixa dúvidas, dá espaço para a transmissão.

Podemos partir da hipótese que a ânsia contemporânea de mudar o mundo e criar um novo mundo é responsável por creditar um suposto saber sobre esses que acabam de chegar as crianças - que ficam, dessa maneira, desprovidas da possibilidade de um saber que é instaurado pela dúvida, essencial para que aconteça a aprendizagem. Em outras palavras, os adultos entregam a criação das crianças não mais a uma sabedoria histórica, de filiação aquela que reflete algo do próprio desejo - mas sim, apostam, principalmente, na psicologia para dizer o que é melhor para que seus filhos se desenvolvam em sua melhor forma, no intuito de ampliar ao máximo suas potencialidades.

Nesse segundo pressuposto de Arendt, é possível perceber a mudança do lugar do discurso do professor: "a fonte mais legítima da autoridade do professor, como a pessoa que, seja dada isso a forma que queira, sabe mais e pode fazer mais que nós mesmos, não é mais eficaz" (ARENDT, 2013, p. 231). Para contrastar com a afirmação de Arendt, vejamos o que Neill (1980) escreve relativamente à autoridade dos adultos sobre as crianças. Para ele, “[...] impor qualquer coisa atrás de autoridade é errado. A criança não devia fazer nada enquanto não mantivesse a opinião - a sua opinião - de que tal coisa deveria ser feita” (p. 107). 
Ficamos diante de duas visões bastante opostas sobre a autoridade do professor em sala de aula ${ }^{7}$, uma vê a autoridade do professor como uma barreira para o desenvolvimento livre da criança e a outra acredita que essa autoridade seja aquela que dá estofo para o lugar daquele que sabe mais, mas que já não é mais eficaz. A oportunidade revolucionária que Neill propõe em sua escola, a de deixar que as crianças tenham total autonomia sobre seus desejos (e sobre a comunidade) e possam comunicá-los, parece ser realmente valorosa para uma época em que, segundo o autor, via suas crianças como aqueles que não têm voz e assim viviam sempre às custas da voz de um outro que lhes diria o que fazer. Todavia, os adultos acabam por abrir mão de sua responsabilidade sobre as crianças e, consequentemente, sobre o mundo, embora seja o adulto que "põe voz" na boca da criança, já que esta nasce sem saber falar e até isso acontecer é falada por um adulto. O mais velho dá forma ao mundo da criança.

Para retomar, apesar da proposta de Neill ter seu valor de renovação para a época, o importante a ser destacado aqui é que, ao mesmo tempo em que impõe a liberdade de escolha pelos alunos, entrega a eles a maior das tarefas humanas - renovar o mundo por sua conta e risco. Contudo, seria como entregar uma herança sem sobrenome, ou seja, uma herança sem passado ou ainda um legado anônimo, resultando no que Freud (1996) expôs sobre a condução da Educação moderna ao afirmar que ela "[...] se conduz como se enviasse a uma expedição polar pessoas vestidas com roupa de verão e equipadas com os mapas dos lagos italianos". (p.137).

O ponto em que Arendt toca, não é simplesmente dizer o contrário de Neill, mas sim, lembrar que se os alunos não pressupõem que ali (no professor) opera um saber, não creditam um lugar de suposto saber, então para eles ali não se passa nada. Para que alguém possa dar a palavra a outro, há que acontecer a suposição de que este alguém possui algo que o outro não sabe e quer saber o que é - há que se instaurar um desejo ou poderíamos dizer, um enigma.

A Educação seria acima de tudo um compromisso político da geração velha para com a geração nova. Carvalho (2013b) resume bem a autoridade ou responsabilidade que alguém que educa tem ao estar todos os dias frente ao novo:

Daí a incontornável responsabilidade do educador pelo legado históricocultural no qual é seu dever iniciar os jovens para que eles possam, futuramente, assumir a dupla e paradoxal responsabilidade de conservá-lo e renová-lo. (p.38).

\footnotetext{
${ }^{7}$ Apesar de Neill estar falando da autoridade de uma maneira geral, consideraremos o âmbito escolar, pois é nesse ambiente que se passam as discussões do autor.
} 
É importante ressaltar, nos dizeres do autor, que é futuramente que essa responsabilidade passará para os jovens, pois, primeiramente, é preciso apresentá-los ao mundo e não "[...]transformar a ação educativa na fabricação de um amanhã utópico[...]" (p.40). Ou seja, depositar nos que chegam a possibilidade de iniciar um mundo totalmente diferente sem que para isso dê a eles um caminho para iniciar.

Carvalho (2013b) também discute a necessidade de renovação das teorias pedagógicas trazendo a discussão para o âmbito político da Educação. O autor relembra um texto de Lefort de 1979 no qual relata que as preocupações com as necessidades sociais e dos poderes públicos com a Educação nunca antes foram tão importantes, porém diz que a ideia éticopolítica de Educação se esvaiu (p.219), ou seja, apesar de já naquela época ser notória a preocupação com a evolução do sistema educacional, surge um paradoxo, como alerta Carvalho, pois mesmo com o interesse do poder público pela Educação, seu sentido não deixa de perder estofo.

Arriscamos dizer que é nesse momento que se inicia a diversidade de atribuições e funções da Educação, em outras palavras: passa-se a destinar cada vez mais fins à Educação, tendo esta que dar conta dos problemas políticos, econômicos e sociais contemporâneos. Podemos ilustrar essa situação com alguns exemplos: educar para a paz, educar para a cidadania, para a tolerância religiosa, Educação financeira e a lista não para de crescer. Carvalho (2013a) ${ }^{8}$ nota ainda que "o que une todas essas iniciativas não são, evidentemente, as finalidades atribuídas à Educação, mas a noção de que a Educação é um meio para um fim que lhe é exterior.”. Desse modo, a Educação carece de significado em meio a todos esses fins a ela atribuídos, inclinando-se a educar mais para diversos fins ao invés de educar em nome de algo, ou seja, em nome do enigma que habita em cada professor. Perde com isso seu significado subjetivante, de entrar em contato o novo e o velho e todas as vicissitudes que este (des)encontro pode trazer.

Essas inquietações relativas à modernização pedagógica refletiram-se no Brasil como em vários outros países - tanto nos documentos oficiais do governo voltados para a Educação quanto diretamente nas escolas com os novos Planos Político-Pedagógicos e nos incentivos sentidos diretamente pelos professores para tornar o ensino mais próximo da realidade e menos conteudista. Essa nova tendência pôde ser sentida principalmente nas escolas públicas e particulares das grandes cidades, que tendem a se preocupar com os

\footnotetext{
${ }^{8}$ Sem numeração de página.
} 
métodos inovadores na Educação para que os alunos possam acompanhar o crescimento acelerado do mundo, rendendo-se à improdutiva competitividade.

De outro lado, Carvalho (2013b) lembra que "[...]o discurso republicano clássico, caracterizado pelo ideal de uma formação escolar voltada ao cultivo de princípios éticos ligados às virtudes públicas, passou a soar como algo cada vez mais distante ou anacrônico" (p.74-75), tão distante que a escola que vemos hoje busca a utópica Educação de qualidade para suprir as necessidades econômicas e do mercado de trabalho. Este foi e talvez ainda seja o discurso dominante na política que deu margem às modernizações da pedagogia para o aluno que, segundo este pensamento, não mais se encaixava nos métodos antigos de avaliação e conteúdo. Carvalho confirma que é à medida que é conferida relação entre qualidade da Educação e seu impacto econômico, ou seja, que a qualidade da Educação influencia na vida econômica do indivíduo no âmbito privado, perde-se seu significado ético-político, ou seja, seu sentido público (2013b, p.75).

Carvalho aponta para um declínio do sentido público da formação escolar, o que nos leva a discutir o terceiro e último pressuposto de Arendt para a crise na Educação. Este pressuposto tem a ver com a substituição do aprendizado pelo fazer. Hannah Arendt afirma que esse discurso se ampara na máxima que somente seria possível aprender o que se sabe fazer. Isto é, ao se flexibilizar o conteúdo dos currículos preferindo a prática à teoria, "a intenção consciente não era a de ensinar conhecimentos, mas sim de inculcar uma habilidade" (ARENDT, 2013, p.232).

O declínio do significado público fica aí evidente, tendo em vista que, ao priorizar uma habilidade, eleva-se a esfera privada em detrimento da esfera pública, tanto no sentido de manter a criança "no mundo dela" quanto aos efeitos econômicos (colocação no mercado de trabalho, por exemplo) que inculcar uma habilidade pode trazer. A autora chega até a afirmar que, com esse foco, as instituições de ensino comparam-se mais a instituições vocacionais, nas quais é valorizado, pesquisado e estimulado aquilo que o sujeito sabe fazer (e não pensar, refletir).

O ensaio de Arendt nos chama a atenção por diversos motivos, tanto por apresentar razões muito plausíveis para uma crise na Educação, quanto paradoxalmente ser uma visão um tanto quanto catastrófica dos novos e da própria modernidade. Acreditamos que no momento da escrita desse ensaio, a catástrofe parecia iminente devido a circunstâncias históricas e pensamos ser muito importante trazer a discussão sobre a crise na Educação que ainda hoje se faz atual. Porém, atualmente, essas questões levantadas por Hannah Arendt 
estariam se encaminhando e tomando outros rumos para uma reflexão acerca da forma como o sujeito está lidando com o social e a Educação.

Por este motivo nossa intenção em discutir o panorama da crise na Educação e o malestar na cultura é encaminhar futuramente a reflexão para o ponto que ressalta ao nosso olhar, a palavra do professor dentro do mal-estar na Educação e sua crise.

É importante lembrar que nosso intuito não é comparar a dita Educação libertária com outros modos de educar, tampouco propor algum resgate. O que importa nesta discussão é visualizar um panorama da crise, lembrando que pretendemos desdobrar e discutir as divergentes e convergentes visões sobre um momento em que a Educação não vai bem, mas, principalmente, escutar o que está no avesso da crise. Ao falarmos sobre esse avesso, nos referimos àquilo que, ao mesmo tempo em que está lá de fato, não se expõe às nossas vistas. Em outras palavras, traçar um panorama que nos permita sair do lugar comum do mal-estar na Educação que tenta achar culpados, mas sim, investigar outros modos de enxergar o malestar. A retomada de Voltolini (2012) ${ }^{9}$ nos é cara neste sentido: "Não se trata de discutir o presente em contraste com um passado que lamentamos ver murchar diante de nossos olhos, mas, antes, de lançar luzes sobre uma série de transformações sociais maiores e destacar nestas o desafio que elas representam".

Como apresentado na introdução, tínhamos o objetivo de entender a relação entre malestar na civilização (ou na cultura) de Freud e a crise na Educação em Arendt e, neste capítulo, pudemos chegar a algumas conclusões. O mal-estar na Educação e a crise na Educação, são somente contextos do mal-estar na cultura de Freud, ou seja, são as formas com as quais os sujeitos contemporâneos estão enfrentando as consequências da modernidade, em diversos âmbitos. Isso não quer dizer que a modernidade inaugurou o mal-estar, pois como já vimos ele é estrutural, mas talvez o tenha trazido à tona para o laço social, forçando os sujeitos a lidar com o inevitável. Freud desvenda o mal-estar pautado no instinto de busca da felicidade, nunca por si realizado, o próprio sentimento moderno. Arendt mostra na crise, a tentativa fracassada, mas sempre presente em nossos dias, de tornar a Educação uma ciência com fins previamente calculados.

Nesse sentido, a crise estaria vinculada a uma busca incessante de sua solução, expulsando seu impossível, o que nos revela novamente somente outra face do mal-estar na civilização de Freud, sendo a crise um acontecimento pontual dentro do mal-estar, que por sua vez seria estrutural do sujeito moderno, da vida moderna.

\footnotetext{
${ }^{9}$ Sem numeração de páginas.
} 


\section{A PALAVRA, A AUTORIDADE E O SUJEITO CONTEMPORÂNEO}

Teceremos, neste capítulo, uma reflexão sobre a palavra, para que possamos posteriormente costurar o que entendemos por autoridade da palavra e seu consequente esvaziamento. Para tal reflexão, valer-nos-emos dos conceitos de palavra plena e palavra vazia, descritas por Lacan (1998), já que nossa dissertação se enreda na teoria psicanalítica. Utilizaremos também outros autores que fazem conversar Psicanálise e Educação.

\subsection{A PALAVRA COMO ENIGMA}

Garcia-Roza (1998) relembra as intervenções de Santo Agostinho acerca da palavra e da verdade. Segundo o autor,

[...]quando falamos não nos propomos a outra coisa que não seja ensinar, posto que, mesmo quando perguntamos, ensinamos ao outro o que queremos saber. O ensino se faz per commemorationem, isto é por relembrança. Falamos para relembrar, para suscitar recordações, nos outros ou em nós mesmos. (p.93).

Depreende-se disso que Santo Agostinho entende as palavras como signos que não remetem diretamente às coisas, mas a outros signos num "sistema fechado" (GARCIAROZA, 1998, p.93), que Lacan irá retomar, ao longo de sua obra, buscando em Saussure e Levi-Strauss a explicação da fluidez e estrutura da palavra, discutindo-a como um significante. Sobre o sistema fechado, a que se refere Garcia-Roza, podemos dizer que seja um sistema infinito, que articula signo-signo, sempre em movimento, em um encadeamento. Agostinho afirmava ser impossível encontrar a verdade na palavra, já que todo signo remeteria a outro, incessantemente, assim, a verdade não habitaria a palavra (p.94), posição que podemos inferir também do estudo da teoria lacaniana quando aponta não existir a verdade, mas sim, meias-verdades.

Lacan formulou uma hipótese fundamental para a elaboração de sua teoria como um todo, a de que o inconsciente é estruturado como uma linguagem. Foi a partir de seu retorno a Freud que pôde desenvolver essa suposição. O "retorno a Freud" na obra lacaniana se refere a exploração da dimensão psíquica da linguagem e a transferência, trazidas inicialmente por Freud, especialmente em suas elaborações sobre o sonho. (DOR, 1989, p.11). Lacan pretendia, escreve Dor, restaurar a "originalidade freudiana da experiência do inconsciente" 
(p.12), ou seja, ao que parece, Lacan estava insatisfeito com o modo como a comunidade psicanalítica conduzia os usos da análise e da transferência e assim propôs o retorno. Escreve Lacan sobre a importância da teoria freudiana especialmente para o ensino da Psicanálise: "Decerto, as formas iniciáticas e poderosamente organizadas em que Freud viu a garantia da transmissão de sua doutrina justificam-se na posição de uma disciplina que só pode sobreviver ao se manter no nível de uma experiência integral" (LACAN, 1998a, p.239-240).

Dizer que o inconsciente é estruturado como uma linguagem significa dizer que percebemos as formações do inconsciente considerando a estrutura de linguagem, ou seja, “[...]é na palavra que o inconsciente encontra sua articulação essencial [...]" (DOR, 1989, p.12). Com essa hipótese Lacan aproxima seu retorno a Freud (baseado no inconsciente) de suas novas articulações com a linguística (representada pelo termo estrutura). O inconsciente estruturado como uma linguagem demonstra a possibilidade de usar a estrutura da linguagem para desvendar algo do sujeito, algo de seu inconsciente.

Por causa do sentido que Lacan atribuiu ao significante, como uma reelaboração de sua leitura do "Curso de linguística geral” de Saussure (1857 a 1913), foi possível pensar na linguagem como um encadeamento de significantes, prevalecendo este sobre o signo, como era para Agostinho. Tal encadeamento não consistiria, portanto, em um significado em si, na busca da verdade como queriam os filósofos da antiguidade, mas, sim, em uma articulação que tem característica interminável, sem uma definição final.

Lacan nota ser fundamental explicar a diferença entre as redes de significante e significado, portanto recorremos ao próprio autor para elucidar tal diferenciação. $O$ significante: "[...]é a estrutura sincrônica do material da linguagem, na medida em que cada elemento adquire nela seu emprego exato por ser diferente dos outros." (LACAN, 1998c, p.415). Já a rede do significado “[...] é o conjunto diacrônico dos discursos concretamente proferidos, que reage historicamente à primeira, assim como a estrutura desta determina os caminhos da segunda.” (1998c, p.415.). Explica o autor que o que prevalece é a unidade de significação que nunca é uma indicação pura do real e sempre remete a outra significação (p.415). O significante está, portanto mais relacionado com a linguagem de cada sujeito e com sua elaboração. Já o significado está no circuito do discurso, sendo partilhado por todos os sujeitos, o que nos permite que nos comuniquemos. A diacronia, utilizada por Lacan para definir o significado, significa, segundo o dicionário Michaelis ${ }^{10}$ "Nome com que se designa a

\footnotetext{
10 Dicionário Michaelis (Moderno Dicionário da Língua Portuguesa) on-line. Disponível em: www.michelis.uol.com.br
} 
transmissão de uma língua através do tempo e das gerações, sofrendo nesse transcurso mudanças fonéticas, mórficas, sintáticas, semânticas e léxicas”.

Lacan discute os conceitos de palavra plena e palavra vazia no livro Escritos (1998a), por meio do texto Função e campo da fala e da linguagem em Psicanálise. Nele, é destacada a importância da fala para a Psicanálise: "Quer se pretenda agente de cura, de formação ou somente de sondagem, a psicanálise dispõe de apenas um meio: a fala do paciente" (LACAN, 1998a, p.248). Por outro lado é importante lembrarmos que “[...]se uma prática analítica é uma prática de linguagem, nem toda prática de linguagem é necessariamente psicanalítica" (DOR, 1989, p.12). Não é somente com Lacan que a palavra se torna fundamental para o exercício da Psicanálise. Seu inventor, Freud, já havia dado o devido destaque ao permitir que sua prática fosse nomeada de talking cure (cura pela palavra), atribuindo grande ênfase à escuta de seus pacientes.

Tomamos a investigação de Calixto (2007) como uma justificativa para a nossa, já que o autor se dedicou profundamente à discussão da palavra na teoria lacaniana.

A investigação do campo da palavra, a luz da Psicanálise enseja uma metodologia própria que reúne subjetividade e objetividade em percepção dialética, por isso, tornou-se necessário aprofundar o que a psicanálise lacaniana aponta sobre a palavra, pois, "uma palavra não é palavra a não ser na medida exata em que alguém acredita nela" (LACAN 1986, p.272), a condição de palavra é intrínseca a um sujeito falante (CALIXTO 2007, p.205).

Além do fato da palavra precisar ser acreditada por alguém - dar crédito a ela quando isso acontece, surge uma resposta para aquele que fala, ou seja, “[...] não há fala sem resposta, mesmo que se depare apenas com o silêncio, desde que ela tenha um ouvinte [...]" (LACAN, 1998a, p.249). Isso quer dizer que é na relação com o outro que se constrói um discurso. Lacan (1953-1954, p.273) completa em outro texto que “[...] a palavra é essencialmente o meio de ser reconhecido [...]é ambivalente e absolutamente insondável". O autor, dessa forma, a define como uma miragem, isso nos asseguraria de estarmos na palavra, sem sabermos se o que o outro diz é verdade ou não (LACAN, 1953-1954, p.273), ficamos com o vazio de nossa interpretação.

Nesse sentido, retomemos a importância da fala na constituição do sujeito. A entrada da criança na ordem da linguagem é sua entrada no registro Simbólico, momento em que acontece o corte da relação dual imaginária, a inserção do grande Outro na vida psíquica da criança, para que ela, por sua vez, possa existir em uma cultura e em uma linguagem, portanto, em uma história. Esse atravessamento para a cultura acontece também pela pergunta 
e inquietação sobre o desejo do outro, formulada inconscientemente como: O que o outro quer de mim? Vemos na formulação dessa pergunta a possibilidade de inserção na linguagem, pois é aí que a criança dará espaço para a entrada do desejo. A palavra do outro enganchará nela.

O elo entre o sujeito e o outro - dado inicialmente na relação dual com a mãe - só é possível pela fala e pela linguagem, contudo, ainda mais pelo encadeamento inesgotável de significantes que a fala enseja: “[...] a palavra tem uma importância fundamental a partir dos 18 meses do bebê, quando a voz do outro endossa suas descobertas sobre si mesmo e o inserirá na cultura pela linguagem". Vemos aí que a linguagem e, mais especificamente, a palavra proferida pelo outro, direcionada ao bebê e é essencial à constituição do sujeito, pois, sem ela (a palavra direcionada carregada de desejo, de intenção, ou seja, a palavra simbolizada), não haveria a passagem à cultura e estaríamos sujeitos a um quadro de psicose (CALIXTO, 2007, p.206).

A palavra é fundante no dispositivo analítico, sem ela não existe análise, ou seja, o analista precisa da fala do sujeito, mesmo que seja feita de pequenos silêncios, mesmo que não faça sentido. A palavra surge de forma cifrada (enigmática, como uma miragem) e está escondida do mundo da linguagem, ou seja, está em seu avesso, assim como o dizer que esconde o dito. “[...] o que parece ser do campo da decifração pode, ao mesmo tempo, ser enigma mais que um saber que se decodifica seguindo um procedimento padrão, a palavra carrega uma dimensão a mais - não perceptível linearmente" (CALIXTO, 2007, p.205). O autor quer ressaltar que apesar da palavra aparecer sempre de forma cifrada, não é da ordem de uma decifração que se trata a análise. Trata-se muito mais da elaboração de um enigma para o sujeito.

É a palavra que instaura na realidade a mentira. E é precisamente porque introduz o que não é, que pode também introduzir o que é. Antes da palavra, nada é, nem não é. Tudo já está aí, sem dúvida, mas é somente com a palavra que há coisas que são - que são verdadeiras ou falsas, quer dizer, que são - e coisas que não são. É com a dimensão da palavra que se cava no real a verdade. Não há verdadeiro nem falso antes da palavra. Com ela se introduz a verdade e a mentira também, e outros registros ainda. [...] o ato mesmo da palavra, que funda a dimensão da verdade, fica sempre, por esse fato, atrás, para além. A palavra é por essência ambígua. (LACAN, 1953/1954, p.261).

Na essência ambígua da palavra que Lacan aponta, nos permitimos enxergar o caráter enigmático da palavra, considerando ser ela quem sustenta o discurso, sem jamais ser totalizante, entregando a verdade. Os sentidos das palavras se tecem na relação, as coisas já estão aí, mas precisamos de palavras para organizar nossa dimensão do discurso e, consequentemente, tecer laços sociais. 
Nesse sentido, é o mundo das palavras que cria o mundo das coisas, disse Lacan. A palavra torna-se o alicerce do dispositivo analítico, sempre visando o sujeito desejante. Sendo assim, a fala é singular do sujeito, já a linguagem, de maneira geral, opera uma lei. Em outras palavras, a linguagem faz parte de um acordo da condição humana, comum a todos, já a fala tem um caráter inconsciente único, que o torna sujeito à linguagem, à cultura.

A fala plena e fala vazia são dois circuitos descritos por Lacan. Iremos refletir sobre esses circuitos nomeando-os algumas vezes de palavra vazia e palavra plena para que auxilie nossa discussão posterior sobre a autoridade da palavra. Pensaremos, nesse sentido, a fala como palavra proferida.

A palavra vazia carrega um invisível, uma linguagem sem som, o silêncio. Nesse circuito o dizer é recoberto pelo dito, ele oculta o dito de alguma forma (CALIXTO, 2007, p.209). A palavra vazia está para além da fala, naquilo que escapa, nos elementos surpresa, nos tropeços. Assim como Freud se preocupou em analisar o mecanismo do chiste conferindo relevante importância aos momentos nos quais os pacientes faziam lapsos e pausas. Trata-se sim daquilo que não se diz, pois o que é dito foi censurado (recalcado).

A fala plena é a que faz ato como revelação e não expressão, ou seja, transcende o discurso ao tornar-se ato: “[...] o efeito de uma fala plena é reordenar as contingências passadas dando-lhes o sentido das necessidades por vir, tais como as constitui a escassa liberdade pela qual o sujeito as faz presentes" (LACAN, 1998a, p. 257), ou seja, a fala plena seria a reordenação dos eventos imaginários acontecidos com o sujeito, descritos em sua fala como atos. Sendo assim, podemos concluir que a palavra plena se concretiza como ato na fala. São as imagens que o sujeito projeta de si, falando de suas representações.

A palavra vazia, que nos é de maior interesse nesta pesquisa, seria, portanto, a própria palavra enigmática, como nos aponta Calixto (2007), por conter um "além da letra, mais que a verdade, mentira ou revelação"(p.210). Encontra-se em outra ordem que não da simbolização. Em uma formulação mais simplificada, poderíamos dizer que a fala vazia é aquilo que o sujeito não diz, que está no avesso de sua fala. Sendo assim, também acreditamos que "um discurso diz sempre mais do que se estima dizer" (DOR, 1989, p.16) e é nesse aspecto que nos convém as falas dos professores.

A palavra enigmática, com efeito de miragem, refere-se a um circuito, assim explanado por Lacan: “Atrás do que diz um discurso, há o que ele quer dizer, e, atrás do que quer dizer há ainda um outro querer-dizer, e nada será nunca esgotado" (LACAN, 1953-1954, p.275) afirmando que a palavra possui uma função criadora. 
Ao dizermos que a palavra é enigmática, estamos também dizendo que ela precisa de um laço para este enigma "grudar", no aluno, por exemplo. Os alunos não mais engancham (fazem laço) no discurso do professor, não deixando espaço em si mesmos para este enigma. É preciso deixar um espaço para o sujeito aluno emergir. "A fala ocupa um lugar estratégico na relação professor-aluno. É ela que cria ou não a própria relação. No entanto, é exatamente esta percepção que tem escapado normalmente aos professores. Eles costumam desqualificar a fala e reduzi-la a processos concretos.” (MRECH, 2003, p.12).

Poderíamos arriscar dizer que a fala é a própria relação entre o professor e o aluno, na medida certa em que é também desproporcional, pois a fala sempre será desproporcional entre o mais velho e o mais novo, como já inferimos das ideias de Arendt. Ressaltamos também que desqualificar a fala e reduzi-la a processos concretos talvez não seja uma ação advinda diretamente do professor, mas da engrenagem pedagógica que permeia seu discurso e sua prática e na qual ele está inserido. Sobre isso, Leny Mrech aponta para a intrínseca relação entre a Psicanálise e a Educação: "Lacan acredita haver ensino somente quando aquele que ensina conseguir tocar o outro, ou seja, se ele conseguir desencadear algo no outro" (MRECH, 2008, p.22). É com base nessa afirmação que abordaremos nossa análise do esvaziamento da autoridade da palavra.

\subsection{AUTORIDADE: AS CRIANÇAS “DE HOJE” E OS "NOVOS TEMPOS”}

Os problemas que a educação enfrenta hoje são divulgados constantemente e circulam no discurso público fortemente. São alguns deles: o fracasso escolar, o mal-estar docente, falta de atenção dos alunos, métodos atrasados e desvalorização do professor. Todos vêm à tona e, não por acaso, para salientar que algo não vai bem com a Educação, fazendo perceber que o tema da autoridade está intrinsecamente ligado a cada um deles.

É bastante comum encontrarmos, para esses problemas, justificativas do tipo: as crianças "de hoje" ${ }^{11}$ não dão mais valor ao conhecimento, a tecnologia trouxe elementos mais interessantes e interativos que a escola, as crianças "de hoje" não respeitam os mais velhos.

Detectamos o discurso de que os tempos são outros justamente na insistência em dizer que as crianças "de hoje" são muito diferentes das de outrora. O discurso pedagógico, no qual

\footnotetext{
${ }^{11}$ As aspas aqui colocadas servem para chamar atenção deste termo como sendo hegemônico no discurso pedagógico.
} 
a Educação está inserida, insiste em considerar que a infância não é mais a mesma, ou seja, que hoje as crianças precisariam de algo diferente do que já precisaram: o novo. Será mesmo que as crianças precisam hoje de algo muito diferente do que já precisaram? É importante considerar aqui que há diferenças nas infâncias de outrora se comparadas às vividas hoje, mas pretendemos salientar, inferindo de nossa reflexão arendtiana, que o fator estruturante da infância - de que são os adultos, por serem os mais velhos, que estão incumbidos da tarefa inevitável de educar - não muda, ou seja, as crianças não podem educar-se sozinhas.

O tempo, portanto, modela de diversas formas essa parte inicial da vida, mas não faz mudar sua estrutura, a de que não é possível se abster de educar. O novo pelo novo entraria, dessa forma, como possibilidade de mudar o que é estrutural, por exemplo, deixando que as crianças experimentem e criem seu próprio estilo de vida em sociedade. "É a sociedade que nos lança fora de nós mesmos, que nos obriga a considerar outros interesses que não os nossos[...]” (DURKHEIM, 1978, p. 45). Lançar-nos fora de nós mesmos é a essência da Educação, pois somente se apresentados aos outros, convocados a entrar no processo civilizatório, só assim e a partir daí é que se oferece a possibilidade de criar o novo, portanto, não será possível dar o novo ao novo.

Boto (1996) sugere que há uma crescente obsessão pelo novo com o advento da Revolução Francesa e da modernidade, e assim começam a ganhar contornos semelhantes ao que vemos perdurar até hoje com relação ao modo de vida dos sujeitos. Especificamente sobre as mudanças no modo de educar, afirma: “A pedagogia revolucionária expressava-se, pois, pela simbologia do discurso engendrado, como uma prática militante da formação do novo homem: emancipado, livre e igual. A Revolução Francesa pretendeu ser a invenção de uma nova forma de ser humano[...]" (p.72).

O cerne da discussão que a autora lança (a influência da Revolução Francesa e os ideais modernos na educação) será discutido nesta pesquisa no capítulo seguinte. Por ora, nos ateremos ao fato desta nova configuração privilegiar aquilo que Arendt registrou em seu ensaio, supondo que um dos fatores que precipitou a crise na educação foi nitidamente creditar nas crianças a possibilidade de deixar para trás um mundo velho que já não agradava e com isso apagar um passado teoricamente impertinente para com isso deixar que as crianças entre elas (sem a interferência dos adultos, pois eles representam aquilo de que não se quer mais saber) pudessem inaugurar, em nome próprio, o novo mundo. Esse contexto alterou a autoridade da palavra.

Surge, no desenrolar desse discurso, a premissa de que os tempos são outros devido à ascensão dos ideais modernos que produziram efeitos no âmbito da Educação. Eis a seguir 
alguns exemplos do discurso hegemônico que circula: "Gestores e professores modernos precisam estimular a criatividade e a busca de novas atividades dentro da escola, diante do novo perfil de alunos" (CARVALHO, 2014, p.14), já outra revista aborda o assunto de maneira diferente: “[...]dispor da tecnologia para dar novos ares à escola, numa tentativa de torná-la menos maçante e mais eficaz no seu papel de levar conhecimento a uma geração que, como eles próprios, é pouco conectada à lousa e ao giz" (BORGES, 2014, p.34).

A ideia de que a escola nomeada de tradicional tornou-se maçante, dominou de forma arrasadora o discurso pedagógico que não demorou a apresentar soluções alternativas à escola dita antiquada. Sugiram, então, escolas atendendo essa demanda, com aparelhagem multimídia de última geração e métodos chamados mais interativos de ensino, o que supostamente faria com que os alunos aprendessem melhor por estarem mais próximos de suas realidades. Não estamos advogando pela volta dos métodos ditos tradicionais de Educação tampouco que a escola nomeada de tradicional funcionava melhor do que a escola atual (o que implicaria em diversas análises sociológicas quantitativas e qualitativas) ou que a lousa e o giz são mais eficazes na educação. O que importa aqui é conseguirmos enxergar que não é exatamente dos meios de comunicação mais inovadores ou menos inovadores que se trata quando estamos falando de levar conhecimento e de transmissão, enfim, trata-se substancialmente da palavra proferida aos alunos, do querer implicar-se com eles, de não se valer do discurso hegemônico e apenas replicá-lo. Sobre isso, Voltolini (2012) ${ }^{12}$ enuncia que, no que toca a Educação "não se trata de discutir o presente em contraste com um passado que lamentamos ver murchar diante de nossos olhos, mas, antes, de lançar luzes sobre uma série de transformações sociais maiores e destacar nestas o desafio que elas representam.”.

"Ensinar, para Lacan, é ir além das práticas estandardizadas: é a recusa de todo tipo de sistema fechado, de modo a descobrir um pensamento em movimento e dinamizar tudo aquilo que estava sendo estudado, como uma convocação ao processo de criação, à estruturação do novo" (MRECH, 2008, p.21). Assim, convocar os alunos ao novo é diferente de esperar deles o novo, sem que haja um chamado, um fio que os conduza, para que possam ser lançados fora de si mesmos, lembrando Durkheim.

Com este cenário em mente, nos permitimos desdobrar um assunto que traz à tona a discussão sobre o advento da escola moderna, já que, muitas vezes, os problemas da Educação recaem no clichê pedagógico de que o advento da modernidade devastou o campo da educação, revelando um destino à escola moderna fadada ao fracasso.

\footnotetext{
${ }^{12}$ Sem numeração de páginas.
} 


\subsubsection{A escola moderna e a autoridade}

A escola moderna, como a conhecemos hoje no Brasil, por exemplo, configurou-se nos fins do século XIX como laica, gratuita e pública, permitindo o acesso de todas as camadas sociais. O panorama social se modificava com o advento da escola moderna e viceversa: "as escolas das cidades apareceram sob uma urgência do século XIX em criar um novo panorama social com ares republicanos e racionais" (PEREIRA, 2009, p.17). Segundo Pereira, a partir do século XVI, diversas reformas religiosas e revoltas sociais e políticas influenciaram a criação de profissões e ciências que puderam tornar vivo o projeto modernizador que contrastava com os ideais do Antigo Regime. Uma dessas profissões, poderíamos prever, seria a do professor republicano, cuja moral imaculada cuidaria de formar “[...] sujeitos éticos dispostos a responder de maneira adequada à ordem vigente[...]” (p.18). Uma das características deste pensamento moderno foi o racionalismo, no qual o homem, “[...] desenvolvendo a mentalidade crítica, questiona a Igreja e a filosofia aristotélica, rejeitando o princípio da autoridade. Assume uma atitude polêmica perante a tradição. Busca a laicização do saber e luta contra os preconceitos e a intolerância” (ARANHA, 1989, p.131).

Um dos passos à escola moderna foi dado graças ao mote republicano e revolucionário que clamava: "Liberdade, Igualdade e Fraternidade". Tal mote configurou-se como palavras de ordem na Revolução Francesa, que consistiu na queda da monarquia absolutista e dos privilégios feudais, aristocráticos e religiosos; simbolicamente foi a abertura para os desdobramentos da era moderna, derrubando os ideais de tradição e hierarquia em nome dos ideais iluministas.

A escola moderna, portanto, já não falaria mais em nome da religião e somente para um público restrito, mas sim "para todos". Os pais passaram a entregar seus filhos a uma educação pública, assim como entregar e justificar sua autoridade a algo muito maior agora, a esfera pública.

Se nos tempos medievais, pré-modernos, a autoridade era transcendente e se achava exclusivamente no ser de Deus ou em seus representantes diretos aqui na terra (papas, reis, pais, mestres, etc.), na modernidade, sobretudo a partir do século XVIII, a Igreja se separa do Estado e a sociedade se torna, pelo menos idealmente, uma sociedade de irmãos, iguais entre si tanto em direitos quanto em deveres. (PEREIRA, 2011, p.57). 
Nesse cenário, observamos que algumas opiniões do âmbito educativo têm tomado rumos diferentes para explicar as consequências disso na vida moderna e na educação.

De um lado, há os que acreditam que essa mudança de paradigma sobre a autoridade e, mais ainda, sob uma ética fraterna (a de que somos todos iguais com direitos e deveres iguais) “deixa vazio o lugar do Pai, de Deus, da Lei, do Estado e de toda instituição social" (PEREIRA, 2009, p.38).

Isso quer dizer que, na escola, o lugar antes do mestre, que estava acima de todos, que sabia mais, não poderia mais existir, já que os motores para colocá-lo nesse lugar não dariam mais conta disso, de acordo com o ideal fraterno. Segundo Pereira (2009) este mecanismo coloca todos como iguais, retomando assim a ideia arendtiana de apagamento das diferenças, pois, com isso, o que se torna alvo mais convicto é a lacuna entre os velhos e os novos. Os novos passam a ter direitos e deveres tanto quanto os que já estavam aqui neste mundo e, assim, muitas vezes, eles nascem sem que, conforme Neill (1980), ninguém lhes diga o que fazer.

Retomando o panorama histórico-social que resultou na ascensão da modernidade, recorremos a Pereira (2009) mais uma vez. O autor retoma as formas de pensamento que regiam cada sociedade ao longo dos séculos e as descreveremos aqui rapidamente. As sociedades arcaicas eram tomadas pelo domínio da natureza; já na Antiguidade clássica eram caracterizadas pelos impérios e também por uma forma mais organizada de comunidade, que gerou as primeiras cidades; em seguida a pré-modernidade foi marcada pela hierarquia, tradição e monoteísmo. A última seria a modernidade "que se dá com a ascensão da burguesia industrial e urbana a partir das revoluções liberais que interrogaram o poder tradicional das sociedades patriarcais" (p.58). O que acontece depois é a laicização do Estado que agora iria reger a sociedade moderna, não mais em nome da Igreja e, sim, em nome do próprio Estado.

Tais mudanças, de acordo com este ponto de vista, acarretaram no declínio da autoridade, sendo a crise na educação a própria crise na autoridade para uns e, para outros, seria o “[...]declínio do sentido público da educação” (CARVALHO, 2013b, p.74).

O declínio da autoridade teria sido, então, consequência de uma sociedade que não tendo mais como referência comum as Leis da Igreja que marcavam a superioridade de Deus, mestres e pais, coloca em seu lugar o Estado que passa a igualar todos com seus princípios republicanos de direito à liberdade e deveres para com a sociedade. Arendt chega até a afirmar que não seria mais possível falar de autoridade, já que, para ela, a autoridade desapareceu do mundo moderno, juntamente, poderíamos dizer, com a tradição. Para a 
filósofa, “[...] com a perda da tradição, perdemos o fio que nos guiou com segurança através dos vastos domínios do passado" (p.130).

Por outro lado, acredita-se que o declínio do poder da Igreja, das crenças metafísicoreligiosas e da família patriarcal, deu lugar à ascensão do Estado como autoridade trazida pela modernidade, permitindo um ganho simbólico. Ou seja, antes da universalização da educação, o poder sobre a educação dos filhos estava calcado na vontade paterna e, posteriormente a essa universalização, os pais se viram obrigados a entregar a educação de seus filhos às escolas e consequentemente ao poder do Estado. O ganho simbólico está na “[...] sobrelevação da esfera pública, e o que viria a proporcionar um sentido inaudito para o compartilhamento da responsabilidade humana pelo mundo" (BATISTA, 2012, p.21-22). Ainda nos explica Lajonquière:

[...] perder algo de sua paternidade em nome de uma outra instância que o ultrapasse, insufla consistência simbólica à própria ideia de pai e além disso, o ganho de consistência simbólica da filiação é efeito do declínio na imagem do pai em nome de uma dívida para com uma instância outra que legisla e ordena (LAJONQUIÈRE, 2000, p.55).

A destituição do lugar do pai (assim como mestres e Deus como detentores da autoridade sobre os indivíduos para dar lugar a uma instância pública) não é vista como uma perda ou como uma ameaça ao próprio laço social - já que do primeiro ponto de vista, fica esvaziado o lugar de autoridade - mas sim, como superação da autoridade arbitrária, em nome agora de algo muito maior e que teoricamente preservaria a herança humana da ruína.

Tudo isso vem contrapor-se à visão de que a modernidade permitiu o declínio da imagem do pai como autoridade maior e também com mestres, Deus e crenças metafísicoreligiosas, ocasionando o declínio da autoridade na vida moderna. $\mathrm{O}$ intuito aqui é pensar que não há degradação nesse passar dos tempos, tampouco defender que houve uma melhoria na civilização, só podemos afirmar que há mudanças, pois ainda as estamos vivendo.

Retomando a ideia central e histórica das consequências do advento da escola moderna, Batista escreve que este projeto tinha como objetivo "educar o homem novo, o homem dos 'novos tempos', isto é, esse homem que, usufruindo da margem de liberdade que nunca pode ser previamente resolvida, se autorizava a tentar alterar o curso preestabelecido para o mundo, ou seja, a gestar no presente um futuro inaudito que se mantivesse simbolicamente enleado ao passado.” (2012, p.99-100). O que o autor quer nos mostrar aqui é que o intuito deste dispositivo era o de criar um novo mundo a partir da educação das 
crianças, bem como a crítica de Arendt enreda. Em outras palavras, a modernidade queria passar a limpo o passado.

A propósito da criação do homem novo, nos é cara a contribuição de Carlota Boto acerca do intuito e conteúdo do Relatório de Condorcet. O Relatório de Condorcet foi uma proposta apresentada pelo francês Marquês de Condorcet, filho de um cavaleiro de família nobre, estudante de filosofia e grande conhecedor da matemática. "[...] ele distinguiu-se como pioneiro da chamada 'matemática social', quando, em 1765, publicou um trabalho que teve, já na época, grande repercussão: Do cálculo integral. A partir daí, ele seria integrado ao movimento enciclopedista, travando estreito contato com intelectuais como Voltaire, Diderot, D'Alembert e muitos outros" (BOTO, 2003, p.740). Seu intuito era unir as ciências morais com as ciências físicas, era, enfim, um estudioso da sociedade.

Quando foi nomeado presidente do Comitê de Instrução Pública da Assembleia Legislativa Francesa dedicou-se a promover a instrução pública e o acesso à escola, especialmente das camadas menos privilegiadas. Desenvolveu o Plano de Instrução Nacional, que não teve a repercussão que ele esperava, mas iniciou uma influência nos projetos votados na Convenção. Apresentou em 20 e 21 de abril de 1792, para a Assembleia Nacional, o mesmo Relatório que havia produzido para o Comitê de Instrução Pública, mas este também não obteve o debate que merecia, pois estavam todos preocupados com a proximidade de um momento decisivo. "Tratava-se naquele momento, de saber o que fazer com o Rei, com a instituição da monarquia e com o curso dos fatos na política da Revolução" (BOTO, 2003, p.742). A ideia central do relatório era buscar uma instrução pública para todos e, principalmente, diminuir as desigualdades. Ele creditava na instrução um papel de esclarecimento e, com isso, o conhecimento permitiria emancipar o homem em sua consciência livre, ou seja, a instrução pública promoveria assim, a igualdade, a razão autônoma e priorizaria os talentos sobre as fortunas (BOTO, 2003, p.741).

O Marquês de Condorcet marcou, portanto, um momento importante na configuração da educação moderna como a conhecemos hoje, promovendo a educação laica, a Pedagogia democrática, uma escola pública universal, gratuita, para ambos os sexos e em todos os níveis, "assinalando como ideal educativo o próprio ideal de nossa sociedade republicana e democrática, ele fixou verdadeiros princípios de educação moderna[...]” (VIAL (1970) apud BOTO, 2003, p.743) ${ }^{13}$.

\footnotetext{
${ }^{13}$ VIAL, F. Condorcet et l'education démocratique. Geneve: Slatkine, 1970. (p.18-19)
} 
É interessante lembrarmos que a Revolução Francesa ocorreu por volta de 1789, portanto as intenções de Condorcet já estavam influenciadas pelos movimentos desencadeados por ela, ou poderíamos dizer que suas ideias fizeram parte das reformas educativas do século e da própria Revolução, assim como muitos outros defensores do homem novo e livre do movimento iluminista (como Rousseau e Voltaire).

Boto (2003) acentua o abandono da orientação trazida pelo Antigo Regime, que já não era mais eficaz e aceita para a criação do homem novo: "O tema da instrução pública perpassava, porém, as discussões, por meio do imaginário que procurava antever o homem novo a ser engendrado para aquela pátria que se desejava liberta dos males daquilo que passou a ser, então, nomeado 'Antigo Regime”" (p.742).

A busca incessante de criar o homem novo, como já nos demonstrou Batista (2012), perseguia um ideal de elaborar no presente um futuro sobre o qual nunca se ouviu dizer, ou seja, algo novo por excelência. Esse homem seria um operário do futuro, como entendemos a partir de Aranha:

[...]o homem novo procurava valorizar os próprios poderes lutando contra o teocentrismo medieval e contra o princípio de autoridade. Tais poderes são intensificados no século XVII pelo racionalismo e pela revolução científica, de modo que o século das Luzes vê surgir um homem confiante, artífice do futuro, que não mais se contenta em contemplar a harmonia da natureza mas quer conhecê-la para dominá-la. (1989, p.151).

Ao que parece, havia um sentimento de dominância nesse novo homem que queria estar no mundo por si mesmo, ou seja, deixando de lado a religião e a natureza, pretendia exercer um poder sobre si. Suas principais reivindicações estavam pautadas em questionar os poderes da Igreja, questionar a filosofia aristotélica, a autoridade, a tradição e promover a laicização do saber.

Concordamos que a mudança na autoridade foi inevitável com a ascensão dos ideais modernos e também benéfica para esse sujeito que não estaria mais amarrado às crenças metafísico-religiosas. Podemos arriscar dizer que não havia de ser de outra forma, no entanto, será que se trataria, a autoridade, de um lugar vazio que sobrou, ou se trataria de um novo jeito de funcionar a vida moderna, uma nova forma de se haver com a autoridade? Os saberes "psi” tomaram pouco a pouco esse suposto lugar vazio da autoridade, ou seja, seguindo esse raciocínio, como não houve algo maior para legitimar a ação educativa, o discurso psicopedagógico (pautado pelo discurso da ciência - sobre o qual desenvolveremos adiante) tomou este lugar. Este é o perigo que incorremos nesse circuito. Quando algo se presta a legitimar um discurso, ficamos sujeitos aos moldes no qual este funciona. 
O incessante questionamento seria: por que nunca alcançamos esse suposto homem novo, tão projetado pelas ideias iluministas? Talvez porque precisemos superá-lo, ou seja, considerar que aquele era o homem novo que o iluminismo prestou-se a configurar e ficou no passado como lembrança e não projetá-lo para um futuro que nunca chega (nem nunca chegará). O que deve importar para a educação é a palavra viva, ou seja, o sujeito que fala e escuta aqui e agora, pautada na fala que enreda uma história que "é o passado na medida que é historiado no presente" (LACAN, 1953\1954, p.21).

4.2.2 A mudança do lugar da autoridade no campo educativo

Diante do exposto, não há mais como não colocar em dúvida o modo como enxergamos a autoridade nos dias que se seguem hoje, afirmamos isso a partir da própria conclusão de Pereira:

[...] não restam dúvidas que a autoridade docente nos dias de hoje vem sendo radicalmente deslocada, que professores não mais encontram apoio num passado supostamente estável para o exercício de seu governo e nem modos sacralizados institucionalmente para evitarem seu desamparo. (PEREIRA, 2009, p.15).

Quase todos os ensaios que tratam de assuntos relacionados à vida moderna caem no mal necessário de se discutir a autoridade. Nosso caso não será diferente. Pensamos ser inevitável tornar um pouco mais visível a discussão sobre o campo da autoridade em uma reflexão trazida pelas áreas da Psicanálise e da Educação para que se edifique mais clara e consistentemente nossa construção posterior acerca da autoridade da palavra.

A palavra autoridade capta em seus sinônimos algo de sua posição na sociedade e nos dá indícios de sua importância, visto o intenso debate sobre seu declínio. São alguns de seus sinônimos: competência, prestígio, ascendência e influência ${ }^{14}$. É interessante notar que tais sinônimos definem sempre algo relacionado ao agente da autoridade e não aos que estão sujeitos a ela. Quando falamos em autoridade também nos vem à memória, as formas de poder, posicionamentos superiores na sociedade, na família, no poder público e até como uma forma de organizar a sociedade, enfim, exercer um comando. A palavra autoridade deriva do

\footnotetext{
${ }^{14}$ Michaelis dicionário de sinônimos e antônimos, São Paulo: Editora Melhoramentos, 2009.
} 
latim auctoritas, que vem por sua vez de autor, que deriva de augere, fazer crescer ${ }^{15}$. Autoria também nos remete ao sentido de estar ali presente naquele momento como autor de algo.

É possível que, com tantos trabalhos já feitos sobre autoridade, ela poucas vezes hoje possa ser confundida com poder, violência ou autoritarismo, por esse motivo partimos para uma reflexão psicanalítica sobre o lugar que a autoridade ocupa no discurso pedagógico.

A palavra autoridade modificou-se com relação ao seu jeito de estar no mundo. Ao mesmo tempo em que é velada nas escolas e no discurso pedagógico, muitas vezes é chamada a ocupar o lugar vazio da causa dos problemas escolares, ou seja, quando os alunos não aprendem a justificativa é a falta de autoridade do professor.

A perda da autoridade deu-se em todos os campos da sociedade e tem sua forma mais extrema e mais crítica no âmbito da educação escolar e familiar, na perda da autoridade do professor sobre seus alunos. O discurso corrente é o de que já que a autoridade está perdida, ou devem os professores dar um jeito de retomá-la, pois só assim os alunos aprenderão ou a culpa recai mesmo nos professores, que não têm controle sobre a classe e que são deixados sozinhos com seus artigos sobre "como retomar a autoridade em sala de aula". Girando, deste modo, em torno da nostalgia da autoridade de outrora que nunca saberemos se foi mesmo imprescindível e benéfica para seus discípulos.

Assumir a responsabilidade sobre crianças é se importar com elas e com o mundo, é querer transmitir uma cultura, um legado, ou nas palavras de Arendt (2013) é uma "responsabilidade que ele assume por este mundo" (p.239). "Ele" neste caso, seria o adulto, o mais velho e na escola, o professor.

Com relação a esse legado como renovação do mundo, Carvalho (2013b) alega que

[...] é em diálogo com esse legado que um indivíduo pode chegar a se constituir como sujeito: como alguém capaz de, ao mesmo tempo, pertencer a uma comunidade cultural e dela se distanciar, criticamente; alguém capaz de deitar raízes em um passado compartilhado, mas manter viva a faculdade humana de romper com suas amarras e criar o novo. (p.26).

Para Arendt chega a ser difícil definir o que é autoridade, já que não podemos “[...]recorrer a experiências autênticas e incontestes comuns a todos[...]” (2013, p.127), sendo assim, o termo perde algo de seu próprio lugar no mundo, dificultando sua explicação e até sua determinação.

Apesar da autora afirmar que a autoridade não existe mais, poderemos pensar que ela existe, mas de forma diferente. Assim, que forma teria tomado? Como poderia estar tão em

\footnotetext{
${ }^{15}$ Disponível em: http://www.anthropos.com.br/280-textos-de-motivacao-e-sucesso/1099-a-autoridade-dolider.html. Acesso em: 22 Mar. 2015
} 
foco, falar-se tanto de algo que já não existe mais? Por isso, abrimos a possibilidade de que a autoridade não exista mais da mesma forma, mas algo dela restou em nossos tempos: se ela ressoa no discurso é porque algo dela ainda (não) queremos saber. Tais apontamentos nos levam a pensar que ela talvez tenha se tornado uma autoridade sintomática.

Se não mais podemos recorrer a algo além de nós mesmos, nos agarrar a um discurso que nos marque e que seja comum - para que então possamos nos diferenciar - faz-nos pensar, qual palavra está sendo dirigida dos mais velhos aos mais novos?

Melman (2008) contribui para a reflexão sobre autoridade ao dizer que "Não há mais autoridade, nem referência, menos ainda saber que se sustente [...]" (p.17). É desse "saber que se sustente" que se trata quando estamos investigando sobre autoridade. Voltolini (2011, p.67) assevera que o termo autorização deriva de autoria, não à toa aqui lembrado, pois é disso que falamos, de estarem ali (os professores), presentes com sua autoria para que sejam autorizados em sua fala.

Kupfer (2007a) também se ocupou dessa temática ao tratar da psicanálise no campo social e no discurso da educação, esclarecendo que, caso faltem "[...]redes de sustentação que possam remeter os sujeitos a uma tradição, a um passado, a significações capazes de orientar as ressignificações do futuro, estamos jogados em um mundo fragmentado" (p.143). Ao dizer isso, a autora alerta para uma fragmentação do mundo em imagens que têm sentido absoluto, sentidos que começam e terminam ali naquela imagem, naquele momento, ou seja, promovem um saber totalizante, sem a inserção de um enigma, sendo que o enigma por sua vez é aquilo que permite a aprendizagem.

A autora faz essa reflexão na esfera da educação ao dizer que o professor de nosso país está sozinho, pois “[...] não encontra mais uma rede de sustentação social para o exercício de seu mandato" (KUPFER, 2007a, p.143), ele é deixado a mercê das expectativas ambíguas tanto do professor mestre, aquele que tudo sabe, quanto do professor moderador da aprendizagem, aquele que deve igualar-se aos seus alunos. Para ela, tal fenômeno não ocorre porque os professores não têm a quem se associar ou programas de melhoria do ensino como as formações continuadas. Deve-se, sim, ao fato de que “[...] o professor não representa mais nada, não fala em nome de uma ordem trans-histórica que o supera, e está jogado à sua imediata e trágica particularidade.” (KUPFER, 2007a, p.143).

Sendo o trans-histórico, segundo a autora, aquilo mesmo que sustenta a ordem, a tradição, a herança, aquilo que ultrapassa as barreiras da história para que não precisemos “[...]sustentar em nome próprio a cultura” (KUPFER, 2007a, p.144). 
Neste ponto, chamamos a atenção para o tom nostálgico que aparece, pois, apesar de não podermos deixar de notar que algo não vai bem com a educação contemporânea, não seria cabível supor que é de uma retomada da autoridade que necessitamos, pois, conforme já nos alertou Arendt, a crise serve para repensar conceitos e dar-lhes respostas novas ou velhas, ou seja, reformular, tecer novas posições dos sujeitos contemporâneos na sociedade. Apesar da trágica particularidade na qual o professor se vê jogado, ele terá que se haver com essa posição (tentando mudá-la ou não) e de seus alunos. Por esse motivo, nossas reflexões acerca da autoridade da palavra são necessárias para entendermos os efeitos do que chamaremos de esvaziamento.

A desautorização docente já é tema recorrente nos estudos sobre educação e nas falas dos professores. Pereira(2009) resumiu a discussão em uma pergunta que estamos tentando desvendar: Será que a profissão docente sofre mesmo da desautorização ou é a própria autoridade que está sendo modificada em nossos tempos? (p.15). Para ilustrar, citaremos um trecho de uma reportagem sobre autoridade na revista Nova Escola: "Ficar irritado, gritar e castigar os que não se comportam como você quer - atitudes autoritárias e retrógradas - não adianta nada. Quando se tenta impor disciplina, a submissão e a revolta aparecem. Hoje, isso não se sustenta mais. O mundo é outro." (MOÇO, 2009) ${ }^{16}$.

Consideramos que a profissão docente vem passando por diversas mudanças no imaginário social, no mercado e nas suas posições de trabalho, assim como vimos no decorrer da história das revoluções liberais. Porém, o que se verifica é uma transformação da autoridade para todos os âmbitos da sociedade de forma a estremecer todo tipo de relação na contemporaneidade. A reflexão que nos permitimos é que já não nos comunicamos mais da mesma forma, não nos vestimos mais da mesma forma, não acreditamos mais nas mesmas coisas; nossas relações mudaram. Portanto, não há nada mais cabível do que a autoridade ter sido modificada. Não afirmamos tal coisa a ermo; Charles Melman, a esse respeito conclui que: "há uma nova forma de pensar, de julgar, de comer, de transar, de se casar ou não, de viver em família, a pátria, os ideais, de viver-se. A emergência de uma nova economia psíquica é evidente[...]" (MELMAN, 2008, p.15). Com uma nova economia psíquica organizando os sujeitos, a autoridade estaria também comprometida, assim também afirma o mesmo autor. Para ele, a autoridade foi eliminada, pois com o desaparecimento do limite não poderia existir mais o lugar de onde este se legitima e se sustenta. (p.25).

\footnotetext{
${ }^{16}$ Sem numeração de páginas.
} 
O que parece incomodar é que, ao contrário de algumas profissões, que aparentemente conseguem dar conta desse novo sujeito contemporâneo, a docência não se encaixa nesse circuito. Ou seja, por maiores que sejam os esforços debruçados sobre a educação, ela ao que nos parece não funciona da mesma forma, ela não é eficiente sob a ótica de mercado e do discurso da ciência (ainda bem, diga-se de passagem). Atribuímos essa diferenciação exatamente pela educação ser um âmbito que trata da fala, da palavra e consequentemente de seu impossível, como já tratamos anteriormente.

É fato, porém, que a profissão docente foi acometida de considerável desgaste intelectual, cultural e econômico e que, no imaginário social, a saudosa noção de mestria, harmônica e sem conflito, cedeu lugar a um profissional sucumbido à massificação industrial, comunicacional e tecnológica de hoje. (PEREIRA, 2009, p.16).

Desastroso é pensar que mesmo passando por toda sorte de inovações e pesquisas a escola não alcançou prestígio e excelência no imaginário social. $\mathrm{O}$ autor define um desgaste do ofício docente. Ao dizer que o professor é agora um profissional que sucumbiu à massificação, retomamos a ideia de Touraine (1998) de que "[...]quanto mais uma mensagem é transmitida massivamente, e sem ligação com o social, menos ela modifica comportamentos" (p.11). Ou seja, a escola atingiu a maioria das ambições da empreitada moderna: torná-la laica, pública, gratuita e para todos, porém, a modernidade tardia cobrou seu preço pela transmissão em massa de ideias sem ligação com o social, como apontou Touraine.

Não podemos deixar de lembrar que esse professor de outrora, teoricamente autorizado em sua função, querido pelos alunos, que reverberava prestígio social, existiu primeiramente na medida do imaginário social da época e também no momento em que a escola limitava-se a ensinar uma pequena parte da população. Não estamos querendo dizer com isto que a má educação de nossos tempos possa ser justificada apenas por estes pontos, mas acreditamos ser importante ressaltá-los para que a comparação seja menos desigual. Enfim, o foco desta pesquisa não é comparar ou confirmar um momento ou outro da educação, é, sim, discutir e refletir sobre o sujeito contemporâneo na escola que é "desautorizada" em suas palavras.

Concordamos que há um sintoma educacional contemporâneo (PEREIRA, 2009), na medida em que é um discurso que se repete, mas ao mesmo tempo nada se quer saber dele, apenas descobrir formas de fugir da crise. 
Sobre o professor, Moser define "Era seu saber e experiência acumulada que lhe permitia ser visto como representante de um discurso constituído - da Razão e da Cultura - ao qual cabia responsabilizar-se e apresentar aos alunos” (MOSER, 2012, p.29). A partir dessa colocação de Moser, sobre a função que o professor tinha em Roma, nos perguntamos por que esta fórmula não é mais eficaz e também se os professores ainda se utilizam desse lugar para transmitir algo.

A autora explica que esse professor transmitia não somente saberes, mas sim visões de mundo a partir do ensino da disciplina com a qual tinha íntima filiação (p.29). Em outras palavras, as disciplinas eram pretextos para o aluno enganchar no saber. É a partir da história do Brasil, por exemplo, que o aluno pode tecer laços com um mundo comum, com a vontade de saber mais sobre aquele assunto, assim, ele pode identificar-se fora de si e sair do engodo de si mesmo. Relembramos, nesta ocasião, a frase de Durkheim (1978) "É a sociedade que nos lança fora de nós mesmos, que nos obriga a considerar outros interesses que não os $\operatorname{nossos[...]”~(p.~45).~Transportando~esta~locução~de~Durkheim~para~a~educação,~é~possível~}$ supormos que a educação também deve-se prestar a nos lançar fora de nós mesmos, a educação poderia ser pensada, neste caso, como descentramento ${ }^{17}$, ou seja, como uma palavra que ao fazer laço nos tire de um circuito ensimesmado e permita buscar novos enfrentamentos.

\subsection{ESVAZIAMENTO DA AUTORIDADE DA PALAVRA}

Pretendemos, neste subcapítulo, alinhavar as discussões anteriores com a hipótese central de nossa pesquisa, o esvaziamento da autoridade da palavra como uma das formas que a crise na educação pode tomar, em um formato de enigma. Primeiramente apresentaremos o autor que fomentou esta discussão e suas principais ideias, em seguida faremos uma introdução aos três registros do inconsciente calcados por Lacan: Real, Simbólico e Imáginário. Entender estes registros será imprescindível para a posterior reflexão sobre o esvaziamento e o que está no avesso dele, ou seja, desvendar alguns indícios do que ocorre hoje com a palavra na educação. Após a reflexão sobre o esvaziamento da autoridade da palavra, apresentaremos a influência que o discurso da ciência tem nesse processo.

\footnotetext{
${ }^{17}$ MRECH, L. Informação verbal
} 
4.3.1 Dany-Robert Dufour: o autor, as ideias.

Dany-Robert Dufour é um filósofo francês contemporâneo, professor de Filosofia da Educação na Universidade de Paris VIII, diretor do programa no Colégio Internacional de Filosofia entre 2004-2010 e residente do Instituto de Estudos Avançados Nantes entre 20102011 ${ }^{18}$. Algumas de suas principais obras são: Os mistérios da Trindade (1990); A arte de reduzir as cabeças: sobre a nova servidão na sociedade ultraliberal (2005a); $O$ divino mercado(2012) e A cidade perversa (2013). Publica regularmente no jornal Le monde diplomatique e na revista Le Débat.

$\mathrm{O}$ autor - no livro que nos é de maior interesse nesta pesquisa, $A$ arte de reduzir as cabeças - sugere a existência de uma nova forma-sujeito sendo instalada. Esse novo sujeito seria resultante da decadência de duas formações subjetivas características do sujeito moderno: “[...]o sujeito do dever, teorizado por Kant, e o sujeito do conflito, trazido por Freud" (BARROS, 2013, p.11), na definição de Dufour (2005a): o sujeito crítico (kantiano) e o sujeito neurótico (freudiano).

Essas formações subjetivas definiam o duplo sujeito da modernidade, como referência para pensar nosso jeito de estar no mundo. O declínio desse duplo funcionamento fez com que outra forma de sujeito começasse a ser instalada em uma modernidade que já delineava traços muito diferentes daquela de Freud e Kant, ou seja, os questionamentos subjetivos passam a ser outros em uma modernidade tardia, diferente daquela delineada por Freud. Surgiria, então, o sujeito que Dufour irá nomear de "sujeito sadeano" (2013) no lugar do duplo sujeito da modernidade. Este novo sujeito estaria calcado no excesso como regra de vida, fazendo parte de um mundo que funciona sob a ordem e a exigência (inconsciente) de gozar a todo tempo, no qual tudo deve ser prazeroso (BARROS, 2013, p.11), o que irá afetar os sujeitos em sua relação com a palavra.

O perigo aqui reside no fato de pensar ser possível capturar uma realidade ideal (de felicidade plena), proposta por esses sujeitos inseridos no circuito do gozo. Esse é o sujeito sadeano - assim denominado devido as proezas do Marquês de Sade, relatadas por Dufour no livro Cidade Perversa e que apontam o excesso como uma nova lei (BARROS, 2013, p.11).

\footnotetext{
${ }^{18}$ Disponível em: 〈〉. Acesso em: 06 Mar. 2014.
} 
Baseando-se nas formulações de Lacan sobre o Discurso do Capitalista, o autor mostrará como esse sujeito, agora inserido não só no capitalismo, mas no estado neoliberal ${ }^{19}$ do capitalismo, tornou-se também objeto de consumo, em um estado de produto. O filósofo desenvolve a crítica ao capitalismo como um sistema que funciona tão bem que "[...]um dia, ele deveria acabar por...consumir a si mesmo" (DUFOUR,2005a, p.9). Sobre o neoliberalismo, denuncia:

O neoliberalismo não visa apenas à destruição das instâncias coletivas construídas ao longo do tempo (família, sindicatos, partidos e, de uma maneira mais geral, a cultura), mas também à da forma indivíduo-sujeito surgida durante o período moderno. (DUFOUR, 2001).

Em outra ocasião resume a essência da reflexão estabelecida em seu livro:

A demonstração era relativamente simples: o mercado recusa qualquer consideração (moral, tradicional, transcendente, transcendental, cultural, ambiental) que possa impedir a livre circulação da mercadoria no mundo. É por isso que o novo capitalismo tenta desmantelar qualquer valor simbólico unicamente em benefício do valor monetário neutro da mercadoria. Dado que não há mais nada senão um conjunto de produtos que são trocados por seu estrito valor comercial, os homens devem livrar-se de todas as sobrecargas culturais e simbólicas que, até há pouco tempo, garantiam suas trocas. (DUFOUR, 2005b) ${ }^{20}$.

Dufour aponta basicamente para uma "dessimbolização", uma perda do âmbito simbólico do mundo, um momento no qual esse terceiro sujeito que surge não tem amarras com o passado, ele seria totalmente livre, o que pode vir a ser muito angustiante, como descreve Szapiro:

Este discurso ao romper com uma continuidade histórica, produz um sujeito desestabilizado psiquicamente, na medida em que lhe faltam as referências que possam ajudá-lo a construir a sua própria ficção, condição de ser um sujeito. Assim, nos processos de subjetivação contemporâneos constitui-se um sujeito que se pretende "liberado", e que, portanto, julga poder prescindir de ancoragens históricas. (SZAPIRO, 2005, p.28).

A autora se refere ao discurso da modernidade tardia, no qual há uma rejeição da dominação de um pelo outro, ou seja, formou-se um sujeito que rechaça qualquer ameaça à sua autonomia. Tomamos certo cuidado com tais afirmações, pois o rompimento da continuidade histórica nem sempre aponta para um fracasso, estamos sempre em um circuito de rompimento e renovação de um mundo comum.

\footnotetext{
${ }^{19}$ O Neoliberalismo é um conjunto de ideias políticas e econômicas, formando uma ideologia econômica que defende o reforço do capitalismo a partir da não participação do Estado na economia, o reforço do setor privado e o aumento da produção.

${ }^{20}$ Sem numeração de páginas
} 
A crise na autoridade - também exposta por Dufour - revela uma crise na função simbólica, ou seja, teria como consequência a própria "dessimbolização" do mundo, estado que reflete a prevalência do Imaginário no mundo contemporâneo, principalmente no que se refere ao campo da Educação.

Dias (2006), baseada em Dufour, afirma que passamos por um momento em que o "[...] mundo como alteridade radical se opõe ao sujeito, se o mundo como alteridade - o Outro social, se altera, o sujeito também se transforma, pois ele não é causa de si, mas se enlaça e se constitui a partir do Outro" (p. 250). Em outras palavras, a empreitada moderna que fez declinar a autoridade em todos os âmbitos da sociedade, alterou o modo como vivemos juntos, como dirigimos a palavra ao outro e como recebemos a palavra do outro.

\subsubsection{Os três registros do inconsciente descritos por Lacan}

Jacques Lacan delineou, ao longo de sua obra, os chamados três registros do inconsciente: Imaginário, Simbólico e $\mathrm{Real}^{21}$. Estes registros serviriam para nomear a organização do sujeito em sua economia psíquica. Lacan os desenvolveu com base na obra de Freud, inaugurando um caminho sui generis na Psicanálise. Será importante entendermos em qual plano eles se situam para que alguns conceitos e relações com a palavra venham à tona.

Tais registros permitem à Psicanálise “[...] teorizar a respeito dos lugares que um sujeito pode assumir nesse campo, nessa relação, bem como os discursos, que a partir destas posições, se desdobram.” (KUPFER, 2007a, p.143). Esse "campo", essa "relação" da qual a autora fala, se trata do campo social em sua dimensão simbólica, pois o sujeito só se constitui na relação com o Outro (o próprio campo social), com a entrada do aspecto simbólico. Os registros também poderiam ser entendidos como "modos com os quais um sujeito aborda os objetos do mundo." (p.143)

\section{O REGISTRO DO IMAGINÁRIO}

O Imaginário compõe um dos três registros fundamentais da psicanálise lacaniana e é pontuado pela hegemonia da relação com a imagem do outro, quase sempre representado pela mãe. A introdução do registro Imaginário é marcada pelo que Lacan chamou de "estádio do espelho", uma de suas primeiras elaborações teóricas. (LAPLANCHE; PONTALIS, 2001)

\footnotetext{
${ }^{21}$ Para que haja uma distinção do imaginário, simbólico e real descritos pelo senso comum, ao nos referirmos nesta pesquisa aos registros expostos por Lacan, grafaremos com letra maiúscula.
} 
Lacan escreveu, especificamente, sobre o estádio do espelho, no artigo $O$ estádio do espelho como formador da função do $e u$, com base na sua preocupação em diferenciar os planos Imaginário e Simbólico. O bebê, ao nascer, é totalmente dependente dos cuidados de um humano, especialmente a mãe, com a amamentação, por exemplo. Nas palavras de Lacan: “[...] esse ser ainda mergulhado na impotência motora e na dependência da amamentação [...] é o filhote de homem nesse estado de infans" (LACAN, 1998b, p.97). Há nesse momento um "inacabamento" do bebê marcado por uma "não-consistência" da imagem de seu corpo, ou seja, não possui uma imagem unificada de seu corpo. Poderíamos dizer que o bebê humano ainda se sente parte da mãe, não se diferenciando dela.

O estádio do espelho se daria, portanto, segundo uma experiência de identificação fundamental. Esse momento é assim nomeado, pois é por meio de seu reconhecimento no espelho que o bebê se lançará na relação dual, especular, iniciada a partir deste outro que o olha. Ele se confunde entre ele e a imagem, sem saber que a pessoa a quem a mãe olha é ele mesmo. Este outro funcionaria como seu espelho. Em outras palavras, o bebê se veria através dos olhos de quem o vê, pautado pelas falas da mãe, os olhos da mãe fariam a função do espelho. Há uma identificação primordial com essa imagem. O bebê começa a entender que aquele com quem a mãe fala é ele e começa a se organizar corporalmente a partir desse movimento.

Essa é a experiência “[...]durante a qual a criança faz a conquista da imagem de seu próprio corpo.” (DOR, 1989, p.79) e a partir da identificação primordial anima a construção do eu. Portanto, o eu ganha consistência desde a relação com o outro, dando estofo para os próximos estágios de constituição do sujeito. Lacan define mais detidamente o processo de identificação, dizendo que é preciso “compreender o estádio do espelho como uma identificação, no sentido pleno que a análise atribui a esse termo, ou seja, a transformação produzida no sujeito quando ele assume uma imagem" (LACAN, 1998b, p.97). O bebê assume que aquela imagem é ele, o que gera uma transformação na criação desse eu primordial. Sendo assim, "[...] essa forma situa a instância do $e u$, desde antes de sua determinação social, numa linha de ficção, para sempre irredutível para o indivíduo isolado" (p.98). Assim, podemos apreender que essa instância do eu primordial ainda não tem marcada a determinação social (que seria a identificação com o Outro), sendo uma organização interna do corpo e imagem do bebê. Nesse momento há somente uma identificação primordial com uma imagem.

Lacan conclui que a função do estágio do espelho é “[...] estabelecer uma relação do organismo com a sua realidade[...]” (1998b, p.100). Há nessa função um movimento de 
exteriorização, ou seja, o bebê começa a se reconhecer como imagem e como corpo e assim, constituir-se. Trata-se de um tempo essencial na formação do indivíduo, que irá marcá-lo em sua história, nunca como lembrança, mas como marca subjetiva. "O estádio do espelho é um drama [...] que fabrica para o sujeito [...] as fantasias que se sucedem desde uma imagem despedaçada do corpo até uma forma de sua totalidade que chamaremos de ortopédica". Há inicialmente um impulso interno que se desdobra "para a armadura enfim assumida de uma identidade alienante, que marcará com sua estrutura rígida todo seu desenvolvimento mental” (LACAN, 1998b, p.100).

Enfim, é nesse tempo que o bebê se situa em uma posição alienada à mãe, como já descrito no início, partilha de uma relação dual, Imaginária, da qual só conseguirá sair se houver um corte. Ao falarmos sobre o Simbólico, explicaremos melhor sobre esse corte.

Kupfer afirma que vivemos, na contemporaneidade, a prevalência do registro do Imaginário, atirados em um mundo fragmentado. $\mathrm{O}$ mundo fragmentado seria o resultado da “[...] falta de redes de sustentação que possam remeter os sujeitos a uma tradição, a um passado, a significações capazes de orientar as ressignificações do futuro [...]” (KUPFER, 2007a, p.143), com uma hegemonia de imagens estáticas e desarticuladas, que possuem uma definição colada a elas mesmas, ou seja, uma relação Imaginária como a da mãe com o bebê, portanto sem corte. São imagens no contemporâneo que não permitem articulação: começam e terminam nelas mesmas, adquirindo um sentido absoluto, que se fecha: "[...]não fazem cadeia, não se articulam com outras na produção de sentidos que lhe são superiores" (p.143). Um objeto passa a ser somente um objeto e não se refere mais a uma cadeia, uma rede anterior a ele e que o sustente. (p.143). Para trazer esse cenário ao âmbito da educação, recorremos à Calixto, que demonstra uma das formas da prevalência do registro do Imaginário na educação: "Na educação, os educadores diante do "fracasso escolar", ao nomear um sintoma, tampona-se a disponibilidade para fazer, o fazer que seria um ir além da palavra implicando-se com o dito." (CALIXTO, 2007, p.220). Ou seja, ao nomear os fracassos escolares como sintomas diversos da criança fecha-se a possibilidade da criança e do professor tecerem uma implicação com suas palavras e com a própria relação que constrói esse fracasso. Enxergamos, nesse exemplo, a prevalência do registro Imaginário, pois fecha em uma nomeação algo que é da ordem de uma implicação professor-aluno. Os sujeitos precisam se implicar com seus atos. (p.220).

Iremos costurar esses conceitos com a educação e o professor ao longo da pesquisa. Neste momento, interessa-nos entender em que âmbito esse registro afeta os sujeitos no mundo. 


\section{O REGISTRO DO SIMBÓLICO}

O Simbólico, em uma continuidade lógica (não cronológica), organiza-se a partir do corte da relação dual Imaginária com a mãe. Tal corte se dá pela introdução da imago ${ }^{22}$ paterna, ou seja, não fisicamente da presença do pai, mas das ausências que o mundo exterior oferece para a mãe, em uma função simbólica de corte. É da alternância entre ausências e presenças da mãe que o bebê vai se constituindo como sujeito do desejo, assim como o inconsciente pulsátil, sempre em movimento.

Essa operação é apenas uma das quais a vida do bebê é permeada para se tornar sujeito do desejo, contudo, uma das mais importantes exatamente pelo fato de introduzir o corte: ela é a castração, conceito que “[...]designa a operação pela qual um sujeito, ao final da travessia do Édipo, se constitui como 'faltante'.” (KUPFER, 1999, p.87).

O plano Simbólico consiste naquilo que nos diferencia dos animais, a linguagem. A passagem ao registro Simbólico seria portanto a entrada do grande Outro na vida da criança. O grande Outro, como já comentamos, refere-se à dimensão simbólica do campo social, a linguagem e a fala. Alude, também, à Lei simbólica, ou ao "mito da horda primitiva" de Freud.

Freud, em Totem e Tabu, apresenta o mito da horda primitiva como uma forma simbólica de explicar o surgimento da civilização e da cultura pautadas no estabelecimento de uma Lei. A horda primitiva originalmente baseia-se na hipótese de Charles Darwin sobre como viviam os homens primitivos. "Deduziu ele dos hábitos dos símios superiores, que também o homem vivia originalmente em grupos ou hordas relativamente pequenos, dentro dos quais o ciúme do macho mais velho e mais forte impedia a promiscuidade sexual" (FREUD, 1969, p.152). Havia nessa horda um pai violento e ciumento que impedia seus filhos de terem qualquer relação com as fêmeas da tribo, guardando todas as fêmeas para si, expulsando seus filhos à medida que cresciam:

Cada um deles poderia, depois de ter sido expulso, estabelecer uma horda semelhante, na qual a mesma proibição sobre as relações sexuais imperaria, por causa do ciúme do líder. Com o decorrer do tempo, isto produziria o que se tornaria uma lei consciente: 'Nenhuma relação sexual entre os que partilham de um lar comum’. (FREUD, 1969, p.153).

\footnotetext{
${ }^{22}$ Sujeito que assume uma imagem. Simplificadamente, poderíamos dizer que se trata de uma representação do pai, no caso (a instância social que o determina em um lugar de corte). O termo antigo é usado desta forma para determinar um "efeito de fase" (LACAN, 1998b, p.97).
} 
Certo dia, narra o mito, os irmãos uniram-se e voltaram para matar e devorar o pai, colocando um fim à horda patriarcal. Ao devorar o pai primevo, os filhos fundavam uma identificação com ele.

Após terem-se livrado dele, satisfeito o ódio e posto em prática os desejos de identificarem-se com ele, a afeição que todo esse tempo tinha sido recalcada estava fadada a fazer-se sentir e assim o fez sob a forma de remorso. Um sentimento de culpa surgiu, o qual, nesse caso, coincidia com o remorso sentido por todo o grupo. O pai morto tornou-se mais forte do que o fora vivo. (Freud, 1969, p.171).

O que era interditado por sua existência real, agora se tornava proibido pelos próprios filhos. O sentimento de culpa colocou o pai na posição de um "totem”, “[...]o totem é o antepassado comum do clã; ao mesmo tempo, é o seu espírito guardião e auxiliar, que lhe envia oráculos, e embora perigoso para os outros, reconhece e poupa os seus próprios filhos.” (FREUD, 1969, p.21). Tal lembrança e sentimento de culpa permitiu ao pai ser colocado em uma posição totêmica e assim instauram-se duas proibições fundamentais: matar o pai e obter satisfação sexual com a mãe.

O mito explanado constituiria o pacto primordial - a primeira regulamentação das relações dos homens entre si, nos distanciando dos animais e marcando o nascimento da civilização.

A civilização seria, em certa medida, a organização coletiva da expiação desse assassinato primordial - tentativa de saldar a dívida assim contraída, destinada porém ao fracasso, já que cada geração é obrigada a transmitir esse legado negativo à geração seguinte. Mas Freud sublinha, por outro lado, que não poderia haver sociedade sem esse pacto de renúncia que a Lei institui. (MILLOT, 2001, p. 72).

O campo do grande Outro e do Simbólico marcam o "[...] lugar da Lei na fundação da civilização e o consequente surgimento de um sujeito que, em razão da própria proibição levantada pela Lei, deseja.” (KUPFER, 1999, p.86). Ou seja, é a renúncia ao gozo que faz surgir o desejo, explicado por Freud no mito primitivo e que hoje funda a cultura e impulsiona os sujeitos para as atividades humanas entre eles. Kupfer explica que "[...] é desse campo - a grande rede simbólica que se estende sob a criança quando nasce - que uma criança poderá extrair o material significante responsável por sua humanização" (p.86). Em outras palavras, o Simbólico instaura a forma como o sujeito humano deve se inserir em uma ordem preestabelecida. (LAPLANCHE; PONTALIS, 2001, p.481).

O registro do Simbólico remete sempre à linguagem, esta é a ordem que constitui e institui o ser falante, que está, por sua vez, atravessado pela linguagem. Segundo Millot (2001), essa determinação falante do ser humano o coloca além de sua condição de vivente, 
ou seja, passa a pertencer ao mundo humano da linguagem. O atravessamento, "rasgamento" ou "divisão" do sujeito pela linguagem produz uma falta que instaura o desejo. Ele é agora um sujeito dividido, marcado pela linguagem, consequentemente pela falta. Toda essa cena “"...] marca simultaneamente a relação do ser humano com o mundo e consigo mesmo, engendra a hiância, que nada pode colmatar, de um desejo confrontado com um impossível gozo[...]" (p.96)

É a partir da linguagem que se produz cultura, em outras palavras, tudo que o homem produz está no âmbito discursivo e é, por sua vez, o discurso que produz laço social. Vemos aí a importância em se considerar o registro Simbólico em nossa pesquisa.

\section{O REGISTRO DO REAL}

O registro do Real caracteriza-se por aquilo que o Simbólico não pode dar conta, ou seja, o que não pode ser simbolizado, colocado em palavras. O Real vai ser definido por Lacan como aquele que escapa à simbolização: “[...] na relação do sujeito com o símbolo, há a possibilidade de uma Verwerfung primitiva, ou seja, que alguma coisa não seja simbolizada, que vai se manifestar no real" (LACAN, 1992; 1992a, p.98 apud CHAVES, 2006, p.162). É também o furo, o que o encontro com esse furo causa, um encontro com o Real. Portanto, o Real escapa ao Simbólico.

Lacan especificou essa falha, essa hiância produzida pelo enxerto da linguagem no ser vivo, como sendo a inexistência de "relação sexual" no ser falante. Entre o homem e a mulher não há, por haver linguagem, nenhuma complementariedade a esperar de sua conjunção, nem harmonia de sua união. (MILLOT, 2001, p.97).

A autora retoma o circuito do registro Simbólico para explicar esse furo causado pela linguagem que determina a não existência da relação sexual. Esta inexistência remete a um impossível de completude, sendo que "o impossível é o buraco cavado no Real pelo simbólico" (MILLOT, 2001, p.97).

O encontro com o Real se repete a todo tempo na vida do sujeito, que por muitas vezes evita entrar em contato com o que esse encontro lhe causa. Por ser o furo constituinte do sujeito dividido, ele sempre irá de encontro com este Real, do qual não quer saber. Esse circuito repete-se infinitamente, delineando o que Lacan conjecturava para o registro do Real: aquele que não cessa de não se escrever. Ou seja, retorna a todo tempo para o sujeito, como que para lembrá-lo de sua condição desejante, humana e incompleta. 
O Simbólico estrutura a realidade humana e como corolário, o homem só tem acesso ao mundo conforme ele faz uso do significante. Assim, o campo do Real é diferente do Simbólico, que ultrapassa o vivido e, dessa maneira o sujeito se imortaliza.

Trata-se, então, da relação do sujeito entrando no corte, num acontecimento denominado de Real, mas que não é simbolizado por nada. Mrech (2005) elucida:

O saber não alcança o registro do real. Este sempre escapa. Além disso, ele revela que o real se caracteriza pela exclusão do sentido. O real independe do sentido para existir. $O$ real independe do saber para se tecer (p.152).

O Real, portanto, não é da ordem do sentido, como ocorre com o Simbólico. Não há nada que possa simbolizá-lo, sempre escapando à elaboração do sujeito.

\subsubsection{Por que esvaziamento e não perda da autoridade?}

A discussão acerca da perda da autoridade da palavra surge, como já indicamos na introdução, da conjectura oferecida por Dufour (2005a).

Subtrair-se à autoridade da palavra conduz, pois, a se subtrair ao mesmo tempo à escrita que leva os seres falantes para os múltiplos aspectos do enigma de sua condição. Inaugura-se, pois, um triste destino para esses novos alunos mal instalados na função simbólica: eles se encontram de algum modo privados de enigma. (p.135).

Foi essa afirmação que nos instigou a pesquisar e indagar: haverá esvaziamento da autoridade da palavra do professor? O que significa dizer isso e quais fatores contribuíram para tal esvaziamento?

Ao darmos início à discussão sobre a perda da autoridade da palavra, logo tratamos de colocar em outros termos, pois, se algo acontece com a autoridade da palavra, recusamos a ideia de perda, tratando-a como um esvaziamento.

Substituir a palavra perda pela palavra esvaziamento de maneira alguma se propõe a dar fim à discussão, ao contrário, a inicia de um ângulo diferente, introduzindo a ideia de que um esvaziamento é um processo que permite reversibilidade, ou em outras palavras que tem uma elasticidade, ao contrário da palavra perda, que é definitiva e brusca, diferentemente de processual.

Neste cenário que se configura, chegamos a questionar como poderia o professor contemporâneo sustentar sua prática frente a uma sociedade que, segundo Dufour (2005a), 
aparentemente encontra-se na perda da autoridade da palavra, sendo que ele define a palavra como possuidora em si mesma de uma autoridade. Tal colocação foi transportada de outro autor, Maurice Blachot: “La parole est toujours parole d'autorité (parler, c'est toujours parler selon l'autorité de la parole)" (1973, p.67). Segundo Blanchot, falar é sempre falar segundo a autoridade da palavra e Dufour (2005a) se utiliza desta afirmação para sustentar suas hipóteses, defendendo que a autoridade nunca é a autoridade de alguém, é, no entanto, o que estaria implicado pelo acesso à função simbólica (p.134), “[...] o que nos faz nos tornarmos sujeito falante no momento mesmo que nos tornamos objeto, até mesmo servo da linguagem" (p.134), ou seja, o que nos diferencia dos animais:

$\mathrm{O}$ universo simbólico refere-se à capacidade essencial que distingue o homem dos animais: a de falar, identificando-se a si próprio como sujeito falante e dirigindo-se a seus semelhantes a partir dessa referência, enviandolhes sinais que supostamente representam alguma coisa. Para ter acesso à função simbólica, basta fazer seu, integrando-o, um sistema onde o "eu" (presente) fala a "você" (co-presente) sobre "ele" (o ausente, ou seja, alguém ou alguma coisa que se trata de re-presentar). (DUFOUR, 2001) ${ }^{23}$.

Falar segundo a autoridade da palavra, seria, então, falar instalado na função simbólica, ou seja, falar de representações, a própria fala inconsciente. Podemos inferir que a autoridade para Dufour se relaciona com o momento de passagem para a cultura, a entrada no Simbólico, saindo de uma relação Imaginária de completude. O autor considera que se essa passagem hoje não é feita, a palavra perde seu peso e assim alunos "mal-instalados" na função simbólica, ou seja, que não fizeram essa passagem, não conseguem se colocar no lugar de alunos, não tem firmados que existe o lugar que fala e o lugar que escuta, impedindo que enganchem na palavra do outro, ou, em outras palavras, que enganchem na cultura.

Relacionando as afirmações de Dufour e Blachot podemos relacionar a autoridade da palavra com a fala vazia de Lacan. Sendo a palavra sempre palavra de autoridade, como determinou Dufour, podemos pensar que há sempre um efeito que a palavra produz no outro e em nós mesmos. Ao que nos parece, Dufour detecta que este processo - da palavra sempre causar um efeito - está hoje fadado ao fracasso, já que percebe, especialmente na escola, que a reação mais comum dos alunos à palavra dos professores é a apatia e o enfraquecimento da função crítica, que nada mais é do que dois lados da mesma moeda: não há enigma, portanto, não há nada a ser desvendado.

Se pensarmos que a palavra é essencial ao professor para, de alguma forma, alcançar o aluno (em seu desejo), tornar-se-á dificultosa sua tarefa ao se deparar com o esvaziamento da

\footnotetext{
${ }^{23}$ Sem numeração de páginas.
} 
autoridade da palavra, ou seja, a palavra não teria efeito sobre o sujeito, não chegaria mais da mesma forma para este. Lajonquière (2011) aponta que o fato de não nos relacionarmos com a palavra é um desejo de não desejar (p.120), ou seja, é um rechaçamento do desejo. Ora, o esvaziamento da palavra denuncia algo na mudança no discurso (como laço social) e consequentemente no modo de funcionar do sujeito.

A autoridade, para Dufour (2005a), é o enredamento dos sujeitos no "fio do discurso". Os alunos de hoje "[...] sentem a maior dificuldade em se integrar no fio de um discurso que distribui alternativamente e imperativamente cada um em seu lugar: aquele que fala e aquele que escuta" (p.134), ou seja, enredá-los no fio do discurso seria uma forma de implicá-los na fala; falados pelo Outro ${ }^{24}$ como sendo aqueles que aqui chegaram depois. Seguindo esta linha de pensamento, caberia aos professores transmitir aos novos por nascimento algo da cultura, das instâncias coletivas e que supostamente permitiria o acesso à função simbólica.

A função simbólica que Dufour discute não é totalmente equivalente ao registro Simbólico calcado por Lacan, tendo em vista que Dufour, ao falar da função simbólica, não faz referência a Lacan. O que o autor chama de função simbólica, nesse caso, se dá pelo discurso, pela transmissão de narrativas, transmissão do dom da palavra, para assim fazer o sujeito identificar-se e situar os outros a seu redor, ou seja, instituir-se como sujeito falante, ou ainda em outras palavras, à medida que conhece o comum e se diferencia pelo seu desejo. Todo esse percurso acontece por meio do discurso, antes e ainda hoje. Fazendo com que nos perguntemos: o que teria mudado no discurso a ponto de influenciar a função simbólica?

O autor defende que uma das razões para essa mudança é a exposição maciça das crianças à imagem da televisão, que substituiu as conversas dentro de casa, e é por meio da conversa entre pais e filhos que se transmite a herança cultural. A televisão não possibilita a transmissão do dom (DUFOUR, 2005a, p.129). Esse “dom” é o de transmitir a palavra, levada a cabo pelo discurso oral frente a frente, do velho frente ao novo, aquele discurso que sustenta a diferença geracional. Sobre a presença bastante precoce da televisão na vida das crianças, constata: "A inundação do espaço familiar por essa torneira permanentemente aberta, de onde escorre um fluxo ininterrupto de imagens, tem efeitos consideráveis na formação do futuro sujeito" (DUFOUR, 2001) ${ }^{25}$

A mudança se configura aparentemente pela relação de uns com os outros, ou seja, se o sujeito moderno influenciado pelo capitalismo se tornou também mero objeto e as pessoas

\footnotetext{
${ }^{24}$ Ao escrevermos Outro com letra maiúscula estamos nos referindo ao grande Outro formulado por Lacan, que seria, nas palavras de Kupfer, a “dimensão simbólica do campo social” (2007a, p.143)

${ }^{25}$ Sem numeração de páginas.
} 
só conseguem se comunicar através dos objetos, perde-se algo relacionado à palavra vazia de Lacan. Segundo este circuito, a palavra está para além da fala, naquilo que escapa, nos elementos surpresa, nos tropeços e essa característica é própria dos sujeitos e não das coisas ou dos objetos. Perder esse traço da palavra acaba por esvaziar ela mesma, num sentido paradoxal, pois a palavra vazia de Lacan seria o contrário de uma palavra esvaziada, precisamos deixar bem claro. O esvaziamento da autoridade da palavra denota portanto o esvaziamento do peso da palavra.

É digno de nota o que alerta Lajonquière: “[...]é impossível que um bebê seja, no limite, criado, educado à distância por videoconferências, por mais coloridas e interativas que elas possam ser para, assim, ele virar mais um ‘formado' da família sapiens”. (2011, p.124)

Assim como a invenção do livro processou mudanças importantes nas formas de simbolização, a entrada da televisão - e também de todos os aparatos eletrônicos na vida da família - instalou uma nova forma de comunicar-se e tal fato tem efeitos consideráveis nas relações dos sujeitos, já que, como mencionado anteriormente, houve uma mudança na transmissão de valores que cabem a cada família (que situa "Joana da Silva" numa família e não em outra) pela transmissão televisiva, que deixa os sujeitos quietos, lhes permite fechar em si mesmos, sem que se preocupem e se incomodem com o outro ao seu lado. Dufour chega a chamar a exposição à televisão de "consumo de imagens". Exposição que, ao mesmo tempo que fala com todos, não dirige a palavra a ninguém - esta seria a função da televisão, atingir somente aquilo que todo sujeito quer sanar, sua falta. Ou seja, ocupar esse espaço com o qual o novo sujeito não quer entrar em contato. Deixar esse espaço é importante, pois a falta não se trata de insuficiência, mas sim "[...]lança o sujeito na busca do que falta para a realização de seu desejo, e o movimenta incessantemente.” (KUPFER, 1999, p.87). É nesse sentido que nos referimos ao mencionarmos o engessamento do sujeito pela influência da televisão e do consumo: visa a suturar a falta, barrando a movimentação do sujeito.

Não poderíamos nesse caso nomeá-la de transmissão televisiva, mas sim, pensar em consonância com Dufour, em um consumo exacerbado de imagens, que enuncia claramente: “não há mais impossível” (MELMAN,2008, p.17).

Essas tecnologias oferecem ao sujeito novas dimensões lúdicas na medida em que ele pode pôr em jogo, no pleno sentido do termo, as referências simbólicas nas quais está construída sua própria evidência ("eu", no cruzamento de um "aqui”" com um "agora"). (DUFOUR, 2005a, p.129).

Segundo Dufour (2005a), para que o sujeito possa 'pôr em jogo' suas referências simbólicas, essas devem estar bem fixadas pela troca discursiva. Ou seja, toda a influência 
imagética de consumo e violência que a televisão veicula - como toda nova prática de linguagem - produz transformações, mas se as referências simbólicas estiverem firmadas, o sujeito é capaz de retranscrever essas imagens em discurso. É fato que o conteúdo veiculado na televisão para o grande público oferece um mundo fragmentado e desarticulado, mas, talvez, ainda nos seja difícil indicar os efeitos que isso pode ter na educação das crianças.

O filósofo é bastante categórico com relação à influência negativa que a televisão causa nas crianças, afirmando acontecer um "embrutecimento" dessas devido ao "empanturramento" causado pela "telinha". Para ele, a televisão está instalada em um "[...]lugar preponderante ocupado por uma publicidade onipresente e agressiva, constitui uma autêntica submissão precoce ao consumo" (DUFOUR, 2001) ${ }^{26}$.

Os alunos, precariamente instalados na função simbólica, estão privados de enigma que, a nosso ver, seria resultado de um discurso privado de desejo e que não instaura a pergunta sobre o outro. Sobre o enigma, Lacan lembra que é um semidizer, algo que só pode ser dito pela metade, como aquilo que dá possibilidade de ser elucidado, coloca dúvidas. Essas crianças, como consequência, têm dificuldade de participar do discurso da escola.

Em certo ponto, o autor retoma Hannah Arendt para justificar tais acontecimentos, utilizando como argumento a perda da autoridade e a não responsabilização dos adultos. $\mathrm{O}$ autor insiste em dizer que é a autoridade que permite aos velhos introduzir o mundo aos novos por nascimento e que paira uma recusa por parte dos adultos em assumir este posto de responsabilização. A visão de Arendt é um tanto catastrófica sobre as consequências da perda da autoridade e vemos também em Dufour indícios de um destino inelutável da educação: o fracasso.

Podemos supor que existe um declínio da autoridade como era conhecida outrora, porém ela tomou muito provavelmente outra forma. Temos que concordar com os dois autores ao defenderem que não seria aceitável colocar no lugar da autoridade a igualdade, nem a coerção, tampouco a persuasão, pois isso seria uma maneira autoritária de trazer ordem ou, em uma análise mais atenta, um modo sedutor dos adultos conseguirem com que os jovens façam o que eles querem, entregando-lhes a culpa do declínio da autoridade. Ou seja, não seria viável a um professor utilizar-se a todo tempo da persuasão para convencer seus alunos de que sua disciplina é importante e interessante. Tampouco seria plausível conversar com seus alunos e chegar a um consenso da melhor forma de passar seus conhecimentos.

\footnotetext{
${ }^{26}$ Sem numeração de páginas.
} 
Parece-nos que o discurso da Pedagogia vem sustentando esta iniciativa (mesmo que inconscientemente) há muito tempo.

Não se trata da retomada ou resgate das antigas (muitas vezes ditas tradicionais) formas de ensinar e da autoridade. Acreditamos que a autoridade (que já é outra) pode estar na palavra, como um enigma. O que nos preocupa é o esvaziamento desse enigma, causado por tantos discursos lançados na educação com vistas a tornar científico o ato de educar. Vemos a palavra do professor (e poderíamos dizer do aluno também) cada vez mais esvaziada de enigmas que permitam enganches do outro. O sujeito contemporâneo parece falar do outro para o outro, tentando capturar, saber o que este outro quer ouvir, em vez de falar de si mesmo e dar a oportunidade para que o outro desvende.

É por este motivo que, ao entrarmos em contato com as ideias de Dufour, especialmente sobre a perda da autoridade da palavra, optamos por nomeá-la de esvaziamento da autoridade da palavra para que possamos pensar a elasticidade de um esvaziamento, ou seja, de que ainda existe algo da autoridade da palavra, pois, se não fosse assim, não teríamos alunos que engancham na palavra e conseguem superar a escola, tornando-se estudiosos e interessados no que a escola propõe.

Outra forma de enxergarmos o esvaziamento da autoridade da palavra seria pensarmos este esvaziamento como uma passagem da palavra que tudo quer significar para uma palavra mais enigmática, o esvaziamento da exclusividade do registro Simbólico como o que pode dar conta de tudo, a mudança do entendimento da palavra apenas como aquela que faz sentido. Saindo, portanto, do circuito de procurar a Verdade e aceitar que a Educação só poderá nos dar meias verdades. Deixando, assim, de acreditar que é através da prevalência do Simbólico que se chegará à Verdade. Sair do Simbólico que captura somente o Imaginário e ir para um Simbólico que também capture o Real. Exatamente porque o Real da escola escapa. Os professores escapam de seus encontros com o Real, chamando os também famigerados especialistas para lidar com as questões de seu dia a dia ou solicitando cursos de formação continuada, pois declaram não poder lidar com determinada situação ou criança por não terem conhecimento sobre aquilo. O conteúdo veiculado nas mídias reafirma a posição do professor como aquele que não sabe sobre sua prática. Para exemplificar, retomemos uma vez mais o artigo da Revista Nova Escola sobre indisciplina: “As estratégias usadas atualmente por parte dos professores para lidar com a indisciplina estão na contramão do que os especialistas apontam ser o mais adequado." (MOÇO, 2009) ${ }^{27}$.

\footnotetext{
${ }^{27}$ Sem numeração de páginas.
} 
Esta seria a posição a ser modificada: não é porque se tem conhecimento sobre algo que se saberá lidar com aquilo, lidar com situações cotidianas do professor requer elaboração psíquica. Sendo assim, [...] será necessário estabelecermos novas formas de vínculo social para que algo da autoridade política do professor seja restituída ou que, uma vez deslocada, seja considerada na experiência”. (PEREIRA, 2009, p.23).

\subsection{DISCURSO DA CIÊNCIA COMO UMA NOVA FORMA DE SE RELACIONAR COM O SABER}

Um discurso, em termos psicanalíticos, refere-se àquilo que produz laço social, ou seja, que vincula e enlaça por algum motivo maior a sociedade, em outras palavras, sobre o que os sujeitos podem falar "em nome de", em forma de estrutura discursiva comum.

É importante considerar a influência do discurso da ciência no circuito que funciona hoje e sobre o qual refletimos nesta pesquisa. Adotaremos a explanação de Lebrun (2004) a respeito do discurso da ciência. A hipótese de Lebrun fundamenta-se na ideia de que o discurso da ciência subverteu o equilíbrio até então em jogo na família e isso tornou de difícil acontecimento o exercício da função paterna. Concebemos essa hipótese de Lebrun como outra forma de fundamentar o declínio da autoridade na modernidade. O autor, apoiado em Nietzsche, acentua que é a vitória do método científico sobre a ciência que marca o derramamento do discurso da ciência no mundo moderno.

Outra importante observação trata de diferenciar a ciência do discurso da ciência, pois o segundo não remete à ciência apenas como conjunto de conhecimento, mas sim às consequências no discurso que ela produziu no campo social. Para Lebrun, ao adicionar o termo discurso nos referimos àquilo que organiza o laço social, no caso da ciência (e mais ainda do método científico) como algo que vem não só organizar, mas modificar o laço social. Mais ainda, sustenta que o discurso da ciência tornou-se "parte integrante do social", não podendo ser considerado uma "produção ilusória localizável" ou uma ideologia. (LEBRUN, 2004, p.54)

O autor aponta as descobertas do século XVI como revolucionárias para a ruptura com uma visão de mundo pautada na religião, ocasionando um abalo das referências. O mundo não seria mais o mesmo após as descobertas de Galileu, Copérnico e Kepler. Esses desdobramentos da ciência guiam uma nova visão de mundo que abala o lugar da autoridade religiosa, antes tida como o sustentáculo do laço social. Produz-se, portanto, um novo laço social, no qual “[...] o que comanda, não é mais a enunciação do mestre, seu dizer, mas um 
saber de enunciados, um conjunto acéfalo de ditos" (LEBRUN, 2004, p.54). O saber (da ciência, entificado, institucionalizado, portanto totalizante) passa a funcionar no lugar da enunciação e da figura do mestre, que tende a se apagar. Lebrun chega a chamar esse saber de "proliferação de competências" o que parece marcar uma nova forma de se relacionar com o saber; a qual não mais passaria pelo saber do mestre e sim por um saber "acéfalo" que não se sujeitaria a nada além dele mesmo. Dessa forma, passa a ser legitimado somente um saber ratificado pelo método científico. $\mathrm{O}$ autor esclarece sobre essa nova relação em um mundo no qual o saber que funciona como bússola promove "[...]uma modalidade de laço social que substitui a relação mestre-sujeito[pela] relação saber (acéfalo)-sujeito.” (p.53).

A ciência, portanto, modificou a legitimidade da autoridade do mestre, considerando que o laço social é produzido no discurso, a autoridade ou legitimidade da palavra do professor também sofre as consequências dessas mudanças.

O efeito do discurso da religião (o qual costumava organizar o laço social) se dava pela organização monocêntrica e vertical da sociedade. Já a ruptura que operou o discurso da ciência, privilegia uma organização plurocêntrica e horizontal do campo social. (LEBRUN, 2004) A ciência passa a operar um papel de autoridade, na tentativa de legitimar uma posição que na verdade não possui, diz Lebrun. Consideramos o discurso da ciência como aquele que promoveu uma primeira ruptura com o discurso da religião. Ruptura que irá se consolidar mais tarde, e de uma vez por todas, na modernidade, com o advento da escola moderna: laica, pública e gratuita.

O nascimento da ciência é um fato - arriscaríamos dizer - difícil de ser pontuado com clareza na história, já que não se sabe ao certo quando o homem passou a se interessar por explicações racionais sobre os fenômenos da natureza. Lebrun considera dois momentos do nascimento da ciência e mais um momento atual da ciência moderna. Os dois momentos de nascimento da ciência teriam sido na Grécia no século VI a.C. e na Idade Clássica. Os gregos pretendiam dar conta racionalmente dos fatos para liberar-se de qualquer referência ao irracional. Naquele momento, a ciência "desejava que a linguagem só fosse utilitária” e que um discurso não estivesse "contaminado pela subjetividade dos locutores" (LEBRUN, 2004, p.56). Apesar de parecerem anseios extremistas, a nosso ver, a ideia da técnica e do método já começaria a tomar forma, já que, de acordo com esse pensamento, para que um método possa ser aplicado e obtenha-se sempre os mesmos resultados é necessário que haja um procedimento sem a influência da interpretação, ou seja, da subjetividade - um discurso sem voz. 
Já na Idade Clássica, segundo momento da ciência, Descartes inaugura a busca de um ponto de certeza para a consolidação das ciências em estabelecer algo durável, acurado e exato que poderia constituir-se apenas por suas próprias ideias. Assim, rompe com o pensamento de Aristóteles que priorizava a coisa em si. Passavam a predominar, no advento da ciência moderna, as ideias.

Em vista disso, Galileu introduziu a matematização do mundo; a natureza seria agora descrita em linguagem matemática, ocasionando uma limitação da cientificidade das ciências à esfera matemática. A tradução das coisas do mundo para uma esfera matemática culminou no seguinte pensamento: “é verdade o que é demonstrável” (LEBRUN, 2004, p.58). Foi assim que o Discurso do método inaugurou o discurso da ciência, reprimindo a busca inicial dos gregos pela verdade e criando métodos que não poderiam ser contrariados, ou seja, fundou a “possibilidade de um saber que não está mais estorvado pela questão da verdade: é um saber sem verdade" (p.58). Este saber sem verdade não se referia entretanto a um saber possível de ser refutado que possibilitasse a dúvida ou o enigma; propunha portanto um procedimento no qual seu fim constituía uma certeza. Lacan explica esta relação entre verdade, sujeito e saber inserido no procedimento de Descartes: “[...] a própria verdade de que dois e dois são quatro é a verdade porque Deus quis que assim fosse. É a rejeição da verdade para fora da dialética do sujeito e do saber que é, propriamente falando, o nervo da fecundidade do procedimento cartesiano[...]" (LACAN, 1965 apud LEBRUN, 2004, p.58-59) ${ }^{28}$.

Nesse momento o saber deixa de ser acumulativo para se constituir apenas por seu próprio procedimento. De outro modo, o saber que antes se encontrava sem posse, era apenas aquele pelo qual o sujeito se constituía, agora, ao que nos parece, o saber se encontra inalcançável, de modo que todo novo procedimento pode gerar uma nova forma de saber, cujas origens estarão sempre apagadas; isso permite, pressupôs Lebrun (2004), que o conhecimento possa ser capitalizado e abra as portas para o mercado do saber. "Assim é conquistada a certeza sobre a qual o saber pode se construir e até ser acumulado.” (p.60).

Lebrun define, assim, o homem da ciência moderna como aquele que apaga o dizer para guardar apenas os ditos passíveis de serem transmitidos e acumulados, esquecendo-se que um sujeito o produziu por meio de um encontro com o real em uma enunciação, culminando enfim em "um discurso esvaziado de qualquer interlocutividade". (2004, p.61).

O movimento no qual os gregos tiveram sua iniciação na ciência era calcado no entrelaçamento entre Real e Simbólico. Era uma tentativa de dar conta do Real por intermédio

\footnotetext{
${ }^{28}$ LACAN, Le seminaire, livro XII, Problèmes cruciaux pour la psychanalyse (1964-1965), inédito, sessão de 10 de junho de 1965.
} 
do Simbólico, isto é, explicar a natureza por meio do pensamento racional, das palavras que nós seres humanos dispomos para traduzi-la. O que muda a partir da ciência moderna é que agora o Simbólico passa a dar conta de tudo sozinho, inclusive do Real. Já apontamos que o Real é exatamente aquilo que não pode ser simbolizado, é o que escapa. Esta é uma impossibilidade estrutural. A possibilidade de tudo significar inaugura o discurso da ciência como aquele que irá instaurar um mundo sem limites. Apesar desta impossibilidade estrutural de dar conta do Real, o discurso da ciência acreditava - e ainda acredita, arriscaríamos afirmar - ser possível chegar a isso, se não naquele momento, algum dia.

Portanto, a palavra do professor, inserida no discurso majoritário da Pedagogia se vê bastante influenciada pelo discurso da ciência. Discurso que pretende, um dia, chegar ao procedimento (ou método) ideal para ensinar as crianças e, para que isso aconteça, consideram essencial conhecer (no sentido neurológico e comportamental) como a criança funciona. Tomam como possível, por assim dizer, a própria educação e o alcance do Real, daquilo que nos escapa, rechaçando o sujeito do inconsciente, desprezando aquilo que sobra da palavra dita. Eis aí a pretensão totalizadora tanto da Pedagogia quanto da ciência quando pretendem fazer crer que seja possível uma autofundação, um modo de funcionar o discurso que não faça referência a nada anterior a não ser suas próprias crenças, uma palavra morta, por assim dizer.

No entanto, se foi este postulado que fez a ciência "[...] se constituir como corpo de conhecimentos e que a transformação progressiva deste em aptidão científica lhe permitiu e ainda hoje permite chegar à eficácia que lhe reconhecemos.” (LEBRUN, 2004, p.62), por outro lado, a Pedagogia não pode vangloriar-se desse mesmo posto, visto que no caminhar desta pesquisa, foi exatamente esta pretensão de se tornar científica que atou as mãos dos professores e minou a autoridade da palavra na educação. Rechaçar a enunciação em um contexto educativo - mesmo que esta intenção esteja de certa forma escondida no discurso pedagógico -, significa silenciar a forma como se permite uma aprendizagem, ou seja, silenciar o discurso do outro e dificultar os enganches da palavra, tanto do professor como do aluno. Como nos esclarece Lebrun, a ciência está em uma posição de domínio e abalo das referências (fato reiterado pela pretensão de dar conta do Real e de um mundo sem limites).

No lugar em que detectamos esta relação do discurso da ciência com o da Pedagogia, Lebrun (2004) nomeia um terceiro momento da ciência, sobre o qual nosso mundo estaria “[...] contaminado pelos efeitos desse progresso [...]” (p.62). Estamos rodeados dos objetos e frutos de sua evolução, coisas que antes nem imaginávamos que poderiam existir, é verdade. Desse modo, incluímos aí a sua influência no discurso da Pedagogia. O autor situa, nesse 
terceiro momento, a viagem do homem à lua como um fato que confrontou os limites até então pensados pela humanidade, alterando a categoria do impossível: “Os novos poderes da ciência traziam a confusão entre deslocar o limite do possível e expulsar o lugar do impossível.” alertando que corremos "[...] o risco de perder o sentido do limite[...]” (p.64).

Há uma perda da relação espontânea com o mundo, diz o autor. Essa perda impõe a premissa de que toda relação (com o saber, por exemplo) deve ser permeada pelo discurso da ciência. Notamos este fato além da redoma da Pedagogia, por exemplo, nos tantos estudos acerca da comprovação da vida de Jesus Cristo e da autenticação de tantas outras formas de crenças que, no passado, eram pautadas apenas pela fé.

Voltando a questão da exclusão do enunciador como sujeito na produção de enunciados - contando que seu êxito dependa desse fato -, a autoridade fica assujeitada apenas aos enunciados "acéfalos". O autor atribui esta posição majoritariamente ao discurso técnico-científico, o qual pretende apagar a enunciação para que não haja vestígios do sujeito. Já ao discurso da ciência não atribui um fim tanto quanto desastroso, já que o cientista ainda se defronta com o impossível. Como já afirmamos, é a vitória do método científico sobre a ciência que marca o derramamento do discurso da ciência no mundo moderno, portanto o tecno-cientificismo seria apenas uma faceta deste discurso que visa a comprovação do mundo sem limites e institui o modo de funcionar do sujeito moderno, esvaziando a autoridade da palavra.

$\mathrm{Na}$ esfera da educação, esse apagamento do enunciador fica bastante evidente, visto que "[...] a absorção da ciência pela escola cria uma regra: todo professor é ali facilmente substituível por outro professor.” (PEREIRA, 2008, P.214):

O aumento do poder do sábio [professor] cuja tarefa é a transmissão; contanto que o indivíduo, instituído em meio a essa transmissão, assegure corretamente sua função, não será considerado como virtude nenhuma de suas capacidades pessoais, exceto aquelas que, por sua transparência e inocuidade, saberão não alterar seu funcionamento; ele é, por essa razão, facilmente substituível (MILNER, 1996, p.102 apud PEREIRA, 2008, p. 214$)^{29}$.

A lógica sobre a qual esse discurso opera (causal e totalitária) faz apagar a subjetividade, isto é, o rechaço da enunciação acaba por silenciar os sujeitos que nela operam (as vezes sem saber que nela operam). "Neutralidade objetiva" e "finalismo universal" são as premissas com as quais Pereira (2008, p.213) delineia o discurso da ciência e seu domínio na vida moderna.

\footnotetext{
${ }^{29}$ MILNER, J. C. A obra clara. Lacan, a ciência, a filosofia. Rio de Janeiro: Jorge Zahar, 1996.
} 
A ideia de silêncio nos é cara, pois expõe o esvaziamento da autoridade da palavra e nos indica um paradoxo, já que o professor é colocado no discurso comum "enquanto portador de uma Verdade de Mestre", porém apenas na medida em que é "veículo da aplicação de um método", ou seja, vítima do discurso técnico-científico que fala às custas dele por não permitir ao professor falar em nome próprio, sendo assim, sua participação na palavra se torna quase nula.”. (PEREIRA, 2008, p. 213). Discutiremos nos próximos capítulos as relações da autoridade da palavra com o discurso da ciência e o lugar do professor no imaginário social. Por ora, partiremos para a análise das entrevistas, abriremos espaço para as palavras dos professores para, então, refletirmos sobre essas relações. 


\section{ANÁLISE E REFLEXÃO DAS ENTREVISTAS COM PROFESSORES DO ENSINO FUNDAMENTAL}

Para tornar mais palpável a discussão proposta nesta pesquisa, consideramos justo ouvir os professores, aqueles que, em algo de sua linguagem, em seu discurso, podem dar-nos indícios (e somente isso) a respeito do esvaziamento da autoridade da palavra.

Ao darmos voz a esses professores por meio de entrevistas semidirecionadas, não tivemos a intenção de, posteriormente, tabular respostas ou verificar dados concretos acerca da educação, mas, sim, com base no discurso desses professores, analisar os indícios, as pistas que nos levam a discutir o esvaziamento da autoridade da palavra além de outras questões intrínsecas ao discurso dos professores que possam surgir, tornando nosso argumento mais consistente.

O objetivo dessas entrevistas é refletir (a partir das palavras proferidas pelos professores) sobre como a crise na autoridade da palavra atinge (ou não) seus discursos e suas impressões quando perguntados indiretamente sobre esse assunto. É interessante chamarmos a atenção para o fato de que, na formulação de nossas perguntas, em nenhum momento perguntamos se o entrevistado percebia ou não um esvaziamento da autoridade, ou uma crise nesse aspecto da educação. O objetivo era entender como o professor percebe o efeito de suas palavras em seus alunos. A cada resposta é possível perceber como as perguntas ressoaram nesses sujeitos, pois, mesmo não perguntados diretamente sobre a autoridade da palavra, alguns entraram nesse assunto. É importante salientar que não nos colocamos como analistas nessa situação, mas sim como pesquisadores da palavra sobre educação, focando na escuta de cada um desses sujeitos que se (des)encontram com seus alunos todos os dias. Portanto, não temos a intenção de desenvolver uma análise (no sentido clínico) dos entrevistados.

\subsection{METODOLOGIA}

Para esta reflexão, tomamos como base os estudos de Elia (1999) e em geral da teoria psicanalítica de escuta do sujeito, pois foi isso que desde o início - como se mostra na Introdução desta pesquisa - capturou-nos, causando o incômodo necessário para buscar respostas e pesquisar. 
Elia $(1999)^{30}$ questiona-se sobre “[...] como poderia um campo de saber-e-prática (uma práxis teorizada, já se o disse muitas vezes) assim constituído admitir uma forma de pesquisa que não respeitasse, de modo axial, suas condições mesmas de constituição?" Tomamos esta pergunta retórica do autor, que nesse momento estaria defendendo a transferência como condição de pesquisa na Psicanálise, para também supor que a palavra e a escuta (mesmo como fala vazia) seriam condições de pesquisa sobre como funciona para nós a reflexão da fala dos entrevistados.

Nessa perspectiva, colocamo-nos diante das entrevistas como "analista-pesquisador" (ELIA, 1999). O analista-pesquisador é aquele que está tomado pelo saber psicanalítico e, ao entrevistar/pesquisar, utiliza esses saberes e práticas como metodologia sustentável da escuta de um sujeito. Sendo assim, a metodologia se fixaria “[...] a cada nova palavra do sujeito: a regra fundamental para o sujeito é dizer sem saber o que está dizendo e o que vai dizer, e para o analista é ouvir sem situar o seu saber já sabido na proa da escuta.”

Tratamos a posição de analista-pesquisador com o cuidado apresentado pelo autor ao lembrar da posição do analista, deixando aparecer as relações com a pesquisa bibliográfica já feita sem que esta, por sua vez, nos paralise em uma reflexão. Em outras palavras, nos permitimos abrir nossos ouvidos para o que esses professores têm a dizer, sem que, para isso, tentemos encaixar suas respostas na pesquisa bibliográfica desenvolvida. Seguindo este pensamento, uma frase do autor é bastante cabível: "É tomado de surpresa quando o sujeito, em vez de lhe dar a palavra que ele cientificamente tanto insiste em obter, se lhe apresenta em ato, em afeto, em transferência." (ELIA, 1999). Ao refletir sobre isso, podemos dizer que a posição do analista-pesquisador, nesse caso, estaria tanto mais relacionada com seu objeto de estudo quanto com o próprio entrevistado, ou, no caso de nossa pesquisa, mais relacionado com a própria palavra do entrevistado.

Sobre a pesquisa em Psicanálise, Elia (1999) sustenta que:

[...] em nenhum outro campo o significado da palavra pesquisa poderia ser tão radical: se pesquisar é ir em busca do que ainda não se sabe, não há campo mais radicalmente estruturado para isso do que o inconsciente, o que a própria materialidade literal da palavra inconsciente já diz. Não há pesquisa de campo em psicanálise, mas o campo de pesquisa que é o inconsciente.

\footnotetext{
${ }^{30}$ Sem numeração de páginas.
} 
A pesquisa em Psicanálise denuncia a do sujeito: estamos sempre pesquisando algo relacionado a um sintoma comum na sociedade, porém naquilo que nos incomoda, nos traz uma pergunta.

A seguir serão apresentados detalhes das entrevistas que consistiram em duas etapas: a primeira um questionário para obter informações pessoais quanto ao perfil do entrevistado:

1. Idade

2. Local de nascimento

3. Local onde viveu maior parte do tempo

4. Formação

5. Tempo no magistério.

6. Como era na sua família a abertura para falar e conversar? Qual era o espaço que as crianças tinham para falar?

7. Como era tratada a autoridade dos adultos sobre as crianças na sua infância?

Nessa etapa nossa intenção era indicar um perfil do entrevistado, tanto no âmbito familiar quanto no âmbito profissional. As perguntas 6 e 7 da Parte I já introduzem o entrevistado no assunto da palavra na esfera da família.

A segunda etapa das entrevistas foi direcionada à prática docente dos entrevistados, constando de outras cinco perguntas:

1. Se você comparar suas ações, sua rotina de sala de aula com a de muitos anos atrás, você percebe alguma mudança na relação dos alunos com a sua palavra? Quais?

2. Quando você professor(a) está ministrando aulas, quais são suas maiores preocupações com o que ou quem está falando?

3. Até que ponto você considera que seus alunos te escutam? Em quais ocasiões? E em que outras isso não ocorre?

4. O que você nomearia como a maior dificuldade para um professor do Ensino Fundamental hoje?

5. De que maneira você acha que os alunos veem você?

Decidimos analisar as respostas das perguntas, uma a uma. Nesse sentido, a cada pergunta, todas as repostas relacionadas serão analisadas e comparadas, conforme nos remetem à teoria anteriormente discutida. As perguntas da primeira parte da entrevista, de cunho pessoal, serão utilizadas sempre que acharmos necessário trazer essas informações.

É preciso considerar que o olhar do pesquisador influencia a fonte pesquisada, é sempre um olhar único, que se tece a partir da escuta dos professores, naquele momento, que fica no 
tempo lógico como figuração do que se tenta captar. Feitas essas considerações, seguiremos para a discussão das respostas obtidas à luz da teoria desenvolvida.

\subsection{INDÍCIOS DO ESVAZIAMENTO DA AUTORIDADE DA PALAVRA NO DISCURSO DOS PROFESSORES.}

A escola escolhida para realizarmos as entrevistas é uma escola pública que fica em um dos complexos do Centro Educacional Unificado (CEU) no município de São Paulo. Preferimos realizar as entrevistas com oito professores, sendo quatro homens e quatro mulheres de uma Escola Municipal de Ensino Fundamental (EMEF), pensando em obter um equilíbrio entre falas e olhares femininos e masculinos. A opção pelo Ensino Fundamental I e II concretizou-se por um ponto empírico trabalhado entre orientanda e orientadora, pois nos parece que é neste nível escolar que as crianças deixam de ocupar o lugar de aluno idealizado, o que ainda na Educação Infantil aparece pela atmosfera lúdica. É também nesse momento que as crianças passam a ter mais de um professor, ministrando disciplinas distintas, sendo assim, os alunos têm um encontro com diferentes modos de proferir a palavra direcionada a eles.

$\mathrm{Na}$ análise das entrevistas, utilizaremos nomes fictícios para preservar o anonimato dos participantes, assegurando assim, a privacidade de cada um. Este estudo possui finalidade de pesquisa e os dados obtidos estão sendo divulgados seguindo as diretrizes éticas da pesquisa.

Nossos entrevistados são:

Carla, 33 anos, de São Paulo, moradora de São Paulo, formada em Pedagogia e professora há onze anos. Ela nos conta, no início da entrevista, que seu pai era mais acessível às conversas dentro de casa do que a mãe, que não tinha muito tempo e "vivia ocupada", assim, as conversas com ela eram mais difíceis. "A gente tinha mais medo dela". Apesar disso, declara que tinha bastante espaço para falar nas conversas em família. Os pais eram a autoridade máxima em casa, muitas vezes não precisando nem falar para se imporem, o que ela considerava ruim, pois ficavam com medo de pedir alguma coisa por conta da resposta que poderiam obter.

Bruno, 48 anos, de São Paulo, morador de São Paulo, formado em Biologia, professor há vinte e um anos. Nas respostas sobre a infância, Bruno começa dizendo que tinha abertura total para falar dentro de casa sobre qualquer assunto. Porém, disse, em seguida, que o espaço que as crianças tinham para falar não era o mesmo que o do adulto, somente o que fosse pertinente à idade era permitido a eles opinar. Sobre a autoridade dos adultos com relação às 
crianças ele destaca que o principal era ensinar princípios e a partir disso as crianças tinham que seguir com respeito e fazer tudo que tinha que ser feito e reitera: "Ninguém nunca precisou me cobrar, eu sempre fui uma pessoa que procurava fazer a minha parte”.

Ricardo, 34 anos, nasceu e mora na cidade de São Paulo, formado em Ciência e Educação Ambiental, professor há quatro anos. Ricardo nos conta que em sua família sempre encontravam um tempo para conversar e se reunir permitindo um diálogo aberto. Nesses momentos, os adultos costumavam fazer questionamentos sobre o dia e sobre a vida das crianças, o que para Ricardo era uma forma de oferecer abertura e voz para eles, considerando que teve uma "infância tranquila". Em sua resposta sobre a autoridade dos adultos ele verifica em sua época uma relação de autoritarismo na escola, mas em sua família a relação era tranquila, sempre com diálogo, sendo que seus pais se orgulhavam por nunca terem batido em seus filhos.

Victória, 38 anos, nasceu em Assis/SP, e moradora de São Paulo, formada em História e professora há treze anos. Ela narra que, por ser filha de pais separados, conviveu com diversos familiares em vários núcleos diferentes, com tias, avós, pai e mãe. Por conta disso, afirma ter tido muito espaço para as conversas dentro de casa e também para a expressão e questionamentos. Victória afirma haver um espaço muito aberto para as crianças falarem em sua família, porém ressalta que essa abertura tinha um limite permissível, adequado e viável, pois a autoridade já estava “implícita e explicita” e, por esse motivo, as crianças já sabiam até onde podiam ir com sua liberdade para falar. Ela aponta, ainda, uma condição diferente de criança em sua época, na qual não era permitido não querer fazer alguma coisa e na época achava essa situação normal, pois " [...] era aquele sentimento mesmo de que é alguém - é um pouco ambíguo isso que eu vou falar - mas é alguém que estava cuidando de mim que eu sabia que ele queria o meu bem e por conta disso eu tinha que ouvir, obedecer o que ele queria para que tudo corresse bem".

Maria, 30 anos, nasceu e vive em São Paulo, formada em Educação Física, professora há sete anos. Ela nos conta que havia uma boa via de comunicação em sua família, mas dependia muito do assunto a ser tratado. Tinham abertura, mas a última palavra era sempre dos pais. Seus pais não pediam sua opinião, tomando sempre as decisões, apenas diziam que quando ela fizesse 18 anos poderia decidir por si. Sobre isso ela declara com humor que esperou muito a chegada dos 18 anos.

Gustavo, 35 anos, nasceu em Maringá/PR, viveu em muitas cidades e atualmente mora em São Paulo. Formado em Geografia e pós-graduado em Ensino de História e Geografia, é professor há dez anos. O professor Gustavo descreve que em sua infância havia uma boa 
abertura para conversas em casa e destaca a atenção e o controle que seus pais exerciam sobre o que faziam ou deixavam de fazer. Contudo, a abertura para conversas não era a mesma com sua irmã, especialmente com o pai. As conversas da irmã eram majoritariamente feitas com a mãe. O espaço que as crianças tinham para falar (no espaço escolar) era pouco em sua opinião, especialmente por ter estudado em um colégio católico no qual havia muita disciplina e sanções. Gustavo fala, ainda, que chegava a ter medo: “a gente não podia na verdade, ficar falando muito. Tinha que mais obedecer e havia sempre um medo pelo o que poderia acontecer se a gente não obedecesse.”. No que concerne a autoridade, ele alega que os adultos possuíam "mecanismos" para estabelecer sua autoridade, tais como: "aquele livro negro, tinha a suspenção, tinha aquela coisa de tirar o aluno da sala de aula, tomava uma bronca ou ia direto para sala do diretor"

Felipe, 35 anos, nasceu e vive em São Paulo. Graduado em Educação Física é professor há catorze anos. Menciona uma quietude maior em sua família, especialmente por parte das crianças, mas havia abertura para conversas e seus pais os questionavam sobre assuntos do dia a dia, no entanto "[...] eu e os meus irmãos sempre fomos muito reservados assim, a gente não abria muito o jogo." Quando enfrentavam problemas sentavam para conversar, mas Felipe destaca que eram os adultos que normalmente percebiam o problema e procuravam ajudar. Com relação a autoridade dos adultos, sua mãe era bastante rígida, nos conta ele, priorizando a opinião dos adultos sobre a das crianças

Manuela, 28 anos, nasceu e vive em São Paulo. Formada em Geografia, é professora há três anos. Manuela relata que as conversas sempre foram abertas em sua família, não havia tabus, declara. Por outro lado, avalia que a comunicação poderia ter sido melhor de maneira geral, destacando que não havia violência por parte dos adultos. A autoridade, para esta professora, era uma "[...]questão de respeito [...] a gente chamava pai de "senhor”, mãe de "senhora". O que eles falavam, a gente fazia. É bem diferente do que hoje em dia a gente vê, né, as crianças já passam por cima das vontades dos pais."

- PRIMEIRA PERGUNTA: Se você comparar suas ações, sua rotina de sala de aula com a de muitos anos atrás, você percebe alguma mudança da relação dos alunos com a sua palavra? Quais?

Ao fazermos a primeira pergunta aos entrevistados, obtivemos respostas bastante diferentes, mas algumas nos chamaram a atenção e iremos refletir sobre isso à luz da teoria que apresentamos. 
A professora Carla de 33 anos - há 11 lecionando - declara perceber que "mudou muito" a relação dos alunos com a sua palavra: "[...] essa questão de autoridade, para eles não existe e eu sempre acho que como em casa eles não têm isso, então, na escola é muito difícil eles entenderem que o professor é uma autoridade, exerce uma autoridade que eles têm que escutar [...]". Essa fala nos faz retornar à ideia de Arendt (2013) de que não seria possível falar em autoridade em nossos tempos, já que ela não existe mais. É interessante notar o que essa professora responde às perguntas iniciais da pesquisa, de cunho pessoal, quanto à autoridade em sua família: “Os adultos tinham autoridade máxima, então... aliás, não precisavam nem falar, né, às vezes, só olhar[...] a autoridade era respeitada, os pais eram autoridade máxima em casa." As duas respostas partem da mesma premissa, a autoridade seria consolidada, para esta professora, a priori, no âmbito familiar e como ela percebe que isto está abalado nas famílias contemporâneas, com base em sua relação com seus alunos, ela conclui que eles não conseguem dar espaço para a autoridade do professor.

Pereira (2009) coloca em foco essa mudança na autoridade que acometeu família e escola, nos explicando que o professor "[...]deixa de ser o exemplo de magnificência, próprio da conjunção de Pai, Mestre e Deus e passa a ser também um precário tanto quanto seus discentes. Algo de sua autoridade é erodido e cinicamente debochado por parte dos nãomestres, os alunos" (p.39). Retoma-se, aqui, a ideia de que os ideais modernos (que perduram até hoje e ganham força) teriam deposto o lugar dos grandes detentores de poder e autoridade até então, sendo alguns deles a Igreja, o Mestre e a família patriarcal. Ao que parece, o discurso que ressoa pauta-se no pensamento de que nossa modernidade tardia ainda sofre os efeitos desse declínio. Podemos dizer mais, sofre da nostalgia do lugar de autoridade que o mestre ocupava.

O professor fica dividido entre duas posições: uma, relativa à lembrança nostálgica do mestre que possuía todo o saber e era (imaginariamente) respeitado e, outra, do professor dito moderno que deve estar frente aos alunos como um mero mediador do ensino, apenas os ajudando a chegar ao conhecimento. Percebemos esse impasse inscrito nas falas de nossos entrevistados por meio das contradições que surgem em suas falas, por exemplo, ao avaliarem a autoridade quando eles mesmos eram crianças, em seguida falarem de sua prática e das mazelas da educação e, finalmente, ao dizerem como acham que são vistos pelos alunos.

Vejamos alguns trechos da entrevista com a professora Carla, para entendermos melhor esse impasse. Na primeira parte das perguntas ela afirma que, quando criança, os adultos representavam a autoridade máxima. Em outro momento ela define um pouco como funciona sua aula: “[...] eles sabem que eu não falo enquanto eles não...eles não escutam, então eu fico 
esperando, com a boca fechada, esperando por eles até o momento de eu falar e é isso que eu tenho conseguido fazer". Por fim, declara como acha que os alunos a veem: "Como eu tô no laboratório de informática, é ainda uma matéria que eles gostam, por ter um computador e ser aula diferente [...] isso faz com que se torne um diferencial”. No depoimento da professora Carla, enxergamos indícios de uma ação pedagógica que a tira de cena quase que totalmente como professora, especialmente ao responder como os alunos a veem. Sua resposta volta-se para o fato de que a disciplina que leciona atrai o interesse dos alunos, passando a impressão que dão pouca importância para sua presença ali.

Podemos olhar duas posições interessantes nessas falas: uma, tenta resgatar ou instaurar um tipo de autoridade como referência nostálgica ao mestre, ao dizer que só fala aos alunos no momento em que eles se acalmam. A outra posição recai na imagem do professor mediador, pois, ao esperar que os alunos se acalmem para que possa falar, está transferindo para os alunos o poder de determinar quando sua palavra poderá ser proferida. Carvalho (2013b) reitera esta posição que se repete nas salas de aula, enunciando que há uma “frequente substituição do termo 'professor' por 'mediador' ou 'facilitador da aprendizagem', signo da recusa da noção de 'ensino' em favor de uma alegada 'aprendizagem não diretiva' e da valorização de uma suposta 'cultura infantil'.” (p.34).

O atravessamento da noção de preservação da cultura infantil na educação permitiu tanto ganhos com relação ao olhar para a criança, quanto fracassos, ao se tornar condição (como tentativa de conhecer a criança em sua totalidade) para a aprendizagem acontecer. Outro autor retoma este "cabo de guerra" no qual os professores se encontram: "O professor parece se situar entre uma moral disciplinadora imposta pelos tempos modernos e uma insurreição de atos subversivos ditada pela contemporaneidade" (PEREIRA, 2009, p.20). Nesse cenário, qual poderia ser o lugar do professor hoje? Consideramos que a dificuldade em responder esta pergunta nos dá indícios do quanto este lugar está flutuante e tensionado.

É interessante trazermos o fato de uma oscilação histórica da palavra com a qual o professor é nomeado, especialmente na Educação Infantil. Em outros tempos, a Educação Infantil, então chamada de Maternal. Era, como o próprio nome já indicava, uma extensão dos cuidados maternos, todavia, em um âmbito público. Naquela ocasião - e este fato perdurou por muitos anos na educação - os professores (e outros que trabalhavam na escola) eram chamados de "tio" e "tia" em vez de senhor ou senhora, atribuindo valores diferentes para a função do professor e declarando algo da ordem da importância da escola e do professor no discurso e no imaginário social. Em uma análise breve podemos perceber a tentativa inicial de um distanciamento da escola repressora de outros tempos, na qual os alunos eram fisicamente 
punidos. O que vemos acontecer depois é uma tentativa da retomada da importância da escola e consequentemente do professor, contudo, ainda como aquela que rechaça o poder autoritário do professor, nomeando-o de mediador, facilitador e outros significantes que indicam uma inclinação a igualar a posição do professor e do aluno.

Os professores entram em conflito com esse discurso perverso que os coloca inevitavelmente em um momento da educação considerado ruim e em declínio constante, com isso, recaem na nostalgia da autoridade, pois, na maioria dos casos, consideram que a autoridade de sua palavra é importante em sala de aula, confirmando isso ao dizer que, quando eram crianças, obedeciam aos mais velhos por motivos que não sabem explicar, apenas dizem que a relação se dava dessa maneira. Alguns exemplos: "Os adultos tinham a autoridade máxima, não precisavam nem falar" (Carla); “ensinar princípios[..]questão do respeito, a questão do cumprimento de horários. Ninguém nunca precisou me cobrar" (Bruno); “a gente vivia em uma outra época né, tinha toda aquela questão de autoridade, ela já tava implícita e explícita”(Victória); "Na minha casa sempre foi tranquilo[...] mas a última palavra é sempre dos pais”(Maria); “Os adultos, eles tinham os mecanismos[..] aquele livro negro, tinha a suspensão"(Gustavo).

Enfim, ao que nos parece, o professor tem internalizado por sua história pessoal (refletida em seu discurso), a importância da autoridade para o exercício de seu ofício, porém, como ela vem sendo renunciada a qualquer custo, especialmente pelas novas tendências da Pedagogia, esses professores não encontram uma sustentação para que sua prática aconteça. Em outras palavras, os professores hoje não podem mais contar com essa ordem preestabelecida, tendo que justificar sua prática e suas decisões nas teorias pedagógicas (pautadas no discurso da ciência que torna a aprendizagem um produto), o que as torna esvaziadas de sentido. Pereira (2011) reitera: “Aquele que ensina não tem mais como vincular sua ação aos valores morais de uma superioridade externa[...]" (p.66). Os professores se veem sem saída nesse contexto e essa angústia vem à tona em forma de queixas constantes acerca das vicissitudes do educar. $\mathrm{O}$ esvaziamento da autoridade da palavra, ou seja, do peso da palavra do professor aparece aqui como o efeito de uma barreira entre o professor e o aluno, transformado em um discurso de queixas nostálgicas como única opção dos professores se colocarem no lugar de vítimas do maquinário "moderno-psico-pedagógico" e em alguns casos se ausentam do encontro de sua palavra com os alunos, talvez até por se sentirem deslocados com tantos olhares de especialistas voltados à Educação. 
Sobre o fundo nostálgico que atravessa a queixa dos professores, Voltolini (2012) ${ }^{31}$ elucida:

Poder-se-ia ver em toda essa nostalgia apenas a expressão de um lamento neurótico que tal como mostrou Woody Allen em seu filme: Meia noite em Paris, se caracteriza por achar que o passado é sempre o melhor lugar para se viver. Mas, por acaso não poderíamos ver também no tom desse questionamento a percepção, mais ou menos enviesada, daquilo que parece ser a marca distintiva de nosso tempo? De fato, a ideia de solvência, de liquidez, de sem gravidade, só para alinhar algumas das tentativas de caracterizar com uma metáfora o selo distintivo de nossa época, parecem retomar a velha máxima marxista de que tudo que é sólido se desmancha no ar.

Ao selo distintivo de nossa época, somamos o esvaziamento. Essa sensação de declínio, perda, decadência e tantos outros significantes que marcam a contemporaneidade só vem para denunciar o mal-estar que vivemos e não conseguimos lidar. Articulamos esse pensamento anteriormente baseado em Freud ao afirmar que o mal-estar é inerente à condição humana moderna e reiteramos com base na noção de crise na Educação forjada por Arendt. Porém, ao que nos parece, alguns discursos visam a abortar esse mal-estar, dando lugar a receitas que distraem e tiram provisoriamente de cena o que detectam como causa do problema.

Nossa abordagem de esvaziamento, visa sair do lugar comum de denúncia e queixa da educação e assim permitir uma abertura para reflexão, já colocada na substituição da palavra perda por esvaziamento, como esclarecemos em capítulo anterior, que permite, por sua vez, a flexibilidade, um episódio em movimento para ser analisado e refletido.

Vejamos a fala de Victória sobre a primeira pergunta. A professora é bastante específica ao comparar seu percurso escolar com a situação em que vê os alunos hoje. Ela nos diz que em sua época "Tinha o entendimento de que aquilo ali era alguma coisa necessária, era preciso ouvir o que o professor tinha a dizer e que, principalmente, tinha uma consequência de não participar, de não fazer, de não permitir que a aula fosse... aliás, nem existia isso, o não permitir que a aula fosse dada, né? Hoje, eles têm o controle da situação. Eles determinam o que o professor vai fazer, o que o professor vai falar, a hora que o professor vai falar, é bastante complicado. Primeiro, você tem que conquistar o aluno para depois, você conseguir fazer alguma coisa.

A queixa de Victória é também bastante comum no campo da Educação e traz à tona a crise na educação demonstrada por Arendt. Em seu ensaio, como já refletimos anteriormente,

\footnotetext{
${ }^{31}$ Sem numeração de páginas.
} 
define três pressupostos básicos para o desencadeamento da crise e, a fala desta professora, nos faz retornar ao primeiro pressuposto que se baseia na crença "[...] de que existe um mundo da criança e uma sociedade formada entre crianças, autônomos e que se deve, na medida do possível, permitir que elas governem.” (ARENDT 2013, p. 229-230). Outro autor também chama atenção para esta conjuntura, ao lembrar que há uma insistência das denominadas hoje pedagogias da autonomia de que "as práticas escolares sejam organizadas de forma a minimizar a interferência exterior às crianças e a estimular sua livre escolha" (CARVALHO, 2013b, p.35).

Pereira (2009) nos coloca uma pergunta bastante intrigante quanto à ponte instável na qual o professor tenta se equilibrar: "Como o professor em nossa contemporaneidade deve fazer valer o apagamento da diferença e, ao mesmo tempo, fazer valer a restauração da autoridade, que a maquinaria pedagógica trata de inculcar?” (p.21). Trata-se de exigências da contemporaneidade completamente contraditórias, como já demonstramos. Essa instabilidade no posicionamento do professor, expedida pelo discurso do senso comum, imprime um efeito de mal-estar que atinge não somente a função docente como também seu próprio discurso sobre a prática. É importante lembrarmos que a posição do professor é marcada inevitavelmente pela imprevisibilidade do efeito de sua palavra, como no início nos alertou Freud para o impossível da Educação. Todavia, esse movimento para o qual Pereira nos alerta é de origem diferente, pois descarta o inconsciente presente do professor e do aluno e igualmente o impossível da educação, pois deixa o professor engessado nesse circuito entre o professor mediador e a restauração da autoridade.

Muitas vezes, esse lugar professoral do imaginário social que (não) ocupam os professores faz com que os alunos retornem com uma violência de natureza real. Nossa entrevistada mencionou essa violência: "eles questionam o tempo todo, mas não é um questionamento sadio, é questionar ações, se você pede para sentar, já é motivo para questionar, eles não querem, porque eles acham que ninguém manda neles, então: 'não preciso sentar, porque você não manda em mim', então é muito complicada essa questão da conversa com eles, porque eles acham que você tá afrontando eles o tempo todo. Qualquer pedido se torna uma afronta, aí uma afronta se torna uma briga, um conflito e aí, resolver conflito é muito mais complicado, mais difícil."

Recorremos a Kupfer (2007a) para compreender a ideia dessa violência na educação: "Diante da falta de violência simbólica, acionam-se no campo da educação, três respostas violentas: uma de natureza real, uma de natureza imaginária e uma de natureza simbólica" (p.144). A violência simbólica que, segundo a autora, está em falta na Educação, seria o que 
estamos tentando desenvolver como autoridade, pensada nos termos de Arendt como sendo política, atrelada às referências institucionais e estáveis na sociedade. Tal violência simbólica trata-se da imposição da linguagem sobre o corpo, ou seja, da própria inserção do sujeito no discurso e na cultura, ela é violenta porque supõe um corte, o corte da relação intrínseca, dual imaginária de mãe e bebê. Seria a própria entrada no registro Simbólico sobre o qual explanamos. É a partir da violência simbólica que os alunos podem vir a se tornar alunos, ou seja, como já demostramos por Dufour, conseguir se posicionar no fio do discurso, instituir o sujeito falante, o sujeito dividido, o sujeito do desejo, assim acessando o universo simbólico.

Conforme entendemos a partir de Kupfer e Dufour, algo desse mecanismo do corte do sujeito não vem funcionando bem em nossos tempos de modernidade tardia. Dufour (2005a) irá chamar de função simbólica mal-instalada e Kupfer esclarecerá que há uma relação entre Lei e desejo na constituição do sujeito, especialmente a castração, que separa a criança do desejo materno (o que já nomeamos acima como a relação dual mãe-bebê). Esse acontecimento instaura a falta, que é estruturante para advir o sujeito do desejo, lembrando que falta não se refere à insuficiência, mas sim, permite lançar "[...]o sujeito na busca do que falta para a realização de seu desejo, e o movimenta incessantemente” (KUPFER, 1999, p.87). O sujeito desejante seria aquele que deseja, pois está castrado. Este corte introduz a criança na ordem Simbólica, ordem da cultura. Podemos conjecturar que esse processo de constituição do sujeito vem se transformando ao longo dos tempos, sem podermos dizer com exatidão de que sujeito se trata em nossa modernidade tardia, apesar de Dufour apontar para a ascensão de um sujeito perverso.

A autora em outra ocasião se posiciona de modo a nos dizer um pouco sobre como esse mecanismo está abalado hoje, falando sobre a posição do professor: "Cada um precisa sustentar em nome próprio a cultura construída por séculos" (KUPFER, 2007a, p.144). Ou seja, esse corte, que a autora chama de violência simbólica, não estaria dando conta de sustentar a cultura, de dizer em nome da cultura para que os professores não precisassem falar em nome próprio, largados à sua particularidade.

Sobre a violência, Dufour (2005a) esclarece que a aparente resistência dos jovens à educação dita tradicional, a própria violência na escola, seria fruto da posição atual do professor mediador e facilitador, que está ali como um igual e rechaça qualquer tipo de controle na sala de aula, inclusive criticando professores que tomam essa posição. O filósofo nomeia esse novo funcionamento da escola de "[...]modelo de talk show televisivo, onde cada um pode democraticamente dar sua opinião.” (p. 142). De acordo com essa visão, a violência dos jovens seria uma resposta aos esforços desses professores que ainda tentam empurrar os 
alunos para a função crítica e ter controle na sala de aula. Essa atitude hoje, por vezes, é considerada pelo discurso da escola libertária na Educação uma afronta ao ponto de vista do jovem. (p.143).

Para ilustrar essa diferenciação de posições do professor, o autor define dois tipos de pedagogo: o pós-moderno e o "simples pedagogo". Os pedagogos pós-modernos seriam os militantes da autonomia da criança e da escola democrática. Este professor, segundo o autor, "renuncia aos trabalhos que eles se tornaram pouco hábeis para realizar" (DUFOUR, 2005a, p.142), ou seja, deixa de oferecer atividades nas quais os alunos não obtêm sucesso, buscando no aluno respostas à sua prática, rechaçando toda e qualquer atividade repressora ou autoridade na escola. Já o "simples pedagogo" é aquele que busca todos os meios possíveis de fazer o aluno entrar no discurso do saber, instalando-se na função proponente e instalando o aluno na função crítica" (p.142).

Os jovens põem em ato a violência, pois se veem sem saída ao não encontrar desproporção geracional entre o professor e o aluno, não conseguem se situar na relação professor-aluno, já que são impelidos a apagar as diferenças. Principalmente não conseguem colocar em palavras o que acontece na sua (não) relação com a escola e partem para o ato, quase sempre de violência ou apatia. Um relato nas nossas entrevistas denuncia essa passagem: "muitas vezes, eles não falam por que que eles estão daquele jeito, não sabem dizer porque" (Gustavo). Nesse trecho o professor estava se referindo aos momentos em que ele percebe que os alunos não o ouvem, momentos de dispersão e o quanto é difícil para os alunos colocarem em palavras os motivos pelos quais se dispersaram, mesmo quando ele (professor) tenta escutar os seus motivos.

Utilizaremos Melman para relacionar a violência e a dificuldade de acesso à palavra: “A violência aparece a partir do momento que as palavras não têm mais eficácia. A partir do momento em que aquele que fala não é mais reconhecido [...] A partir do momento em que esse reconhecimento não ocorre, o outro não é mais reconhecido como sujeito, e a violência sobrevém." O autor alerta ainda que a violência "se tornou um modo banal de relação social" (2008, p.69) "não se fala mais, faz-se a guerra" (p.71).

A professora Victória, também dá sua resposta à mesma questão de outra forma, colocando o foco na necessidade da Educação apresentar-se obrigatoriamente como prazerosa, enveredando para o outro lado da violência: "a gente vive numa situação em que o aluno, ele quer o prazer constante. Então, ele quer uma situação em que ele seja sempre permeado de satisfação plena." 
A sensação de necessidade de satisfação plena e de prazer constante também é uma marca de nosso tempo, o qual, como já entendemos em Dufour, é permeado pelo neoliberalismo, que fincou suas raízes no capitalismo somado a nova forma de funcionar o sujeito moderno, pautado nos excessos. O mesmo autor chama a atenção para esse dispositivo do prazer que funciona na escola: "Decerto podemos decidir que, já que eles não o podem mais, não se deve mais pedir-lhes que o façam" (DUFOUR, 2005a, p.135). Fala neste momento das escassas condições dos alunos entrarem no fio do discurso, fio que deveria permitir ao professor elaborar proposições pautadas em um saber acumulado pela cultura direcionado ao aluno e, a partir disso, discuti-las. Ele continua:

[...] é assim que uma grande quantidade de pedagogos, armados das melhores intenções do mundo, progressivamente vieram a suprimir todos os exercícios que os novos alunos não sabem mais fazer. Que estranha resposta quando se pensa nela um instante: ela é do mesmo tipo que a de um médico que quebrasse o termômetro para tratar da doença (DUFOUR, 2005a, p.135).

Essa discussão remete-nos à formulação freudiana tão inaugural quanto atual sobre a necessidade dos homens de encontrar um estado de felicidade definitivo, movimento que é estrutural da condição humana como já afirmamos. Contudo, a modernidade tardia, associada ao discurso da ciência - a própria crise -, fez crer aos indivíduos da espécie humana que esse seria um cenário possível.

Retomando nossa articulação com Freud, lembramos que a felicidade foi definida por ele como uma manifestação ocasional, sendo aquela que deve ocupar um curto espaço de tempo para gerar no sujeito a sensação de felicidade: "Somos feitos de modo a só podermos derivar prazer intenso de um contraste, e muito pouco de um determinado estado de coisas." (FREUD, 1996, p.84). Ou seja, não poderia haver um estado constante de felicidade para o homem. Almejar um estado constante de felicidade parece estar intrínseco ao sujeito do contemporâneo e para isso a ideia de acabar com os limites parece tentadora. Charles Melman nos coloca frente a uma inquietação bastante intrigante sobre a possibilidade de viver sem limites a felicidade plena. Ele questiona: "Como saber que se está na realidade? Quando despertamos, pela manhã, como sabemos que o sonho parou? Decerto é porque tomamos contato com uma forma de decepção que organiza nossa realidade.” Ele continua dizendo que se essa decepção nos falta - esse choque com o real - em uma vida na qual tudo é possível, estaríamos sempre sonhando? (MELMAN, 2008, p.28).

Melman parece completar o panorama da modernidade tardia, que já lida com um mundo sem limites, enquanto Freud nos traz o cenário da modernidade que desponta com as 
grandes angústias do homem moderno. O prazer constante, sobre o qual Freud decretou uma impossibilidade, hoje tenta, por intermédio de um discurso pautado no mercado e no neoliberalismo (como apontou Dufour), fazer-se real.

O professor Gustavo analisa o que podemos olhar como outro efeito da Educação essencialmente prazerosa ao dizer que: 'Hoje em dia, talvez por uma liberdade maior ou porque tem uma coisa do imediatismo atualmente, que as pessoas querem as coisas pra hoje, agora”. Podemos pensar que, com a percepção de Gustavo sobre o imediatismo, a palavra não tem tempo lógico de chegar ao aluno, de capturá-lo em seu enigma. Escutamos esse resultado ainda nas falas deste professor: “eles querem tudo pra já, pra agora. Então, eles são crianças muito ansiosas e que não sabem esperar, não sabem se concentrar, ler um comando para poder saber o que tem que fazer, eles já querem sair fazendo e muitas vezes, eles nem sabem o que estão fazendo”. Conseguimos pressupor, com base nessa fala, que os alunos "nem sabem o que estão fazendo" exatamente porque não conseguem ler um comando para saber o que devem fazer, como nos relata Gustavo. Ou seja, os alunos não emprestam seus ouvidos às falas do professor nem sequer para que possam entender a atividade proposta. A ansiedade relatada também nos leva a crer que os alunos padecem da necessidade de "passar ao ato", ou seja, querem apenas executar a tarefa (mesmo que nem saibam do que se trata) e não se permitir uma elaboração psíquica, a qual promoveria um processo de aprendizagem "não prazeroso".

"O tempo que eles ficam atentos a gente é muito menor, a gente consegue mantê-los atentos por cinco minutos ouvindo. O restante tem que ser com atividades práticas, senão eles dispersam." (Gustavo). Essa queixa do professor Gustavo é bastante comum na Educação e nos indica a absorção do discurso da Pedagogia que prima por manter a aprendizagem como um processo agradável, em que os alunos devem gostar de aprender. Como já dissemos, a aprendizagem implica elaboração psíquica, o que nem sempre será prazeroso. As atividades práticas seriam mais uma vez uma forma de privilegiar o ato na educação, depositar valor somente naquilo que pode ser transformado em objeto.

A fala vazia e a fala plena reveladas por Lacan e retomadas para reflexão nesta pesquisa se fazem sempre presentes na palavra. Nesse caso, o que intentamos ressaltar, especialmente com as entrevistas, é o fato da fala vazia não se apresentar mais como enigma, nem para o aluno, tampouco para o próprio professor. Em algumas conversas, os professores parecem falar de um lugar que não pertence a eles ou ao qual não pertencem, como já ressaltamos sobre a fala da professora Carla que, ao ser perguntada como os alunos a veem, responde que como no momento está no laboratório de informática e é uma matéria que eles 
gostam, se torna um diferencial; em nenhum momento considerando que a sua presença ou modo de conduzir as aulas poderia ser admirado pelos alunos.

Por outro lado, O professor Bruno revela uma percepção interessante sobre o momento em que sua palavra atinge os alunos: "a partir do momento que a pessoa vê porque que ele tá aprendendo determinados conteúdos, ele passa a valorizar o estudo, né? Logicamente, que a gente não consegue isso aí com todos, mas com uma boa parcela”. Pelo discurso comum da Pedagogia, arriscaríamos dizer que esse professor estaria se referindo ao momento em que o aluno verifica uma relação com sua vida cotidiana e, como consequência, aprende. Em uma reflexão pautada na Psicanálise e em nosso objeto de estudo, a partir do momento em que o aluno se identifica, se engancha nas palavras do professor, o assunto se ilumina para ele. Como já expressamos, os conteúdos escolares seriam pretextos para o aluno se enganchar no desejo de saber.

Detectamos, ao acaso, uma contradição interessante de ser analisada. O professor Gustavo nos diz ao responder sobre a escuta dos alunos: "a maioria me ouve, mas eu tenho um número maior de pessoas que não ouvem”. Vejamos bem, vale lembrar que não nos interessa, com essas análises, condenar nenhuma atitude ou fala de algum professor, apenas ouvir o que eles têm a dizer sobre sua prática e confrontar com a teoria que desenvolvemos. Enxergamos um lapso relevante nessa fala, pois, ao mesmo tempo em que percebe que a maioria o ouve, logo trata de dizer que um número maior não o ouve. Poderíamos nos perguntar: afinal, para este professor haveria mais alunos que o escutam ou que não o escutam? A resposta reside exatamente na impossibilidade de respondê-la, dado que, há algo da fala vazia, a fala inconsciente que se esconde por trás do dito, que não podemos acessar: há aqui um enigma. É esse enigma que anima a presente pesquisa, pois ao final, não poderemos afirmar com certeza (porque é impossível) se existe o esvaziamento da autoridade da palavra do professor. Como já indicamos no início, podemos somente apontar indícios e reflexões.

Outra forma de olharmos o equívoco da fala do professor, seria nos remetendo à formulação de Lacan sobre a palavra, na qual ele a define como uma miragem, em que não sabemos ao certo o que é verdade e o que não é. Nas palavras do autor: "O que ela diz, será que é verdade? Será que não é verdade? É uma miragem. É essa primeira miragem que lhes assegura que estão no domínio da palavra.” (LACAN, 1953-1954, p.273).

"A gente acaba perdendo um pouco esses alunos". Gustavo diz que, no momento em que os alunos não estão ouvindo sua fala, ele consequentemente perde esses alunos, o enganche da palavra ali foi perdido, o fio que os liga. 
- SEGUNDA PERGUNTA: Quando você está ministrando aulas, quais são as suas maiores preocupações com o que e quem está falando?

Analisando as respostas que obtivemos para essa segunda pergunta, encontramos três falas frequentes com relação às suas preocupações em sala de aula: uma se refere aos alunos entenderem porque estão aprendendo determinado conteúdo, a outra seria se eles entendem o que está sendo passado e por último tentar fazer com que a realidade deles se encontre de alguma forma com o conteúdo que é passado pelos professores em sala. Todas elas apontam para o que discutimos nos capítulos anteriores relativos à mudança na posição e no pensamento do professor hoje, denunciando uma preocupação insistente: estabelecer o conteúdo escolar como aquele que "faz sentido" para o aluno. Notadamente são muitas as preocupações que passam pela cabeça desses professores que entrevistamos, o que pode acabar por engessá-los nessa necessidade de se fazer entender.

Separamos alguns exemplos: "Primeira preocupação minha é levar temas que são relevantes para os alunos[...] mostrar para o aluno porque que ele tá aprendendo aquele conteúdo(Bruno); me preocupo se eu tô me fazendo entender (Ricardo); a minha maior preocupação é poder transmitir o conteúdo para eles, fazer com que eles consigam assimilar e entender o que eu tô falando[...]Você construir essa ponte entre o que ele está vivendo (Victória); Que eles compreendam o real objetivo do que eu tô fazendo, porque, o significado do que vai ser feito, né?(Maria); se eu vou conseguir trabalhar o maior número de alunos possível, criar interesse no maior número de alunos possível (Felipe); Eu fico preocupada em me fazer entender, que às vezes, eu acho que talvez eles não compreendam a forma que eu estou falando (Manuela).

Vemos nessas falas a necessidade que margeia a Educação de formar uma ponte que se inicia no professor, passa pelo conteúdo e chega à criança. Um dos professores chega até a citar como preocupação "construir a ponte". Todos eles com certeza não estão errados, afinal todas as respostas foram bastante interessantes e mostraram professores preocupados com o entendimento de seus alunos. O que nos chama a atenção é que na pergunta anterior muitos se queixaram que seus alunos não os escutam, que não conseguem manter a atenção das crianças, o que nos leva a retomar a ideia de que a palavra não atinge os alunos, mas, da mesma forma, especialmente a palavra do professor, seu peso se esvaziou. O esforço desses professores para atribuir significado às suas práticas é notável em suas falas, no entanto, considerando que perguntamos sobre suas preocupações em sala de aula, suas respostas mostram que ainda há uma preocupação muito grande com a forma com que a informação dada por eles irá chegar ao aluno. 
Tal preocupação nos parece ser uma herança do segundo pressuposto de Arendt no qual a função do professor estaria calcada em entender como a criança apreende a informação e não tanto no quanto o professor conhece da disciplina. Tal mudança foi pautada sob a entrada das teorias de aprendizagem e desenvolvimento que construíram a "criança psicológica", sobre isso nos explica Mrech (2003): "Há uma crença geral de que basta saber como o aluno em geral funciona [...] para saber como ele se apresenta na prática" (p.5). Acreditamos que essa crença apareça hoje ainda, porém de forma camuflada, no discurso dos professores, como herança desse pensamento que tem perdurado por muitos anos na Educação.

O professor Ricardo mostra em sua resposta a preocupação com o retorno que o aluno precisa lhe dar para que saiba que está sendo compreendido: "me preocupo com quem tô falando, preciso da atenção, né, que eles estejam envolvidos, de certa forma, que perguntem, que tirem dúvidas, acho que é essa a minha preocupação". Perguntar e tirar dúvidas seria o oposto da apatia trazida por Dufour e é nessa linha de pensamento que Ricardo baseia sua preocupação: a atenção dos alunos nesse caso são suas palavras dirigidas ao professor sobre o conteúdo de sala. Envolver os alunos seria traçar o fio que permite que a autoridade da palavra do professor apareça, situar os alunos na relação de aprendizagem como voz ativa a partir da palavra do professor. Já o professor Bruno expressa uma opinião diversa de Ricardo com relação ao modo de envolver os alunos em sua palavra: "Primeira preocupação minha é levar temas que são relevantes para os alunos, que tenham alguma utilidade na vida deles, lógico que existe o currículo, mas em cima disso daí [...] eu procuro ver, mostrar para o aluno porque que ele tá aprendendo aquele conteúdo.” Na fala de Ricardo aparece outra tendência da Pedagogia atual, ensinar aquilo que faz parte da vida do aluno:

\footnotetext{
A renovação do ideário pedagógico trouxe consigo legitimidades científicas e uma nova atenção ao olhar. Na antessala do conhecimento do que lhe cabe ensinar, o professor deve dar as boas-vindas aos doutos que a moderna ciência soube firmar[...] o imperativo é respeitar a personalidade do aluno e moldar o ensino a sua natureza (MOSER, 2012, p.41).
}

Esse seria o modo dos conteúdos curriculares da escola fazerem sentido para o aluno, mas, nesse caso, corre-se o risco da palavra do professor ficar presa nessa preocupação em conectar sua disciplina com a realidade do aluno, o que nem sempre é possível, como nos relata Victória: "História é uma matéria muito difícil, é muito subjetivo para eles, né, não é uma coisa concreta, não é uma coisa que tá falando exatamente do que o que o cara vive. Você construir essa ponte entre o que ele está vivendo, o que passou é o mais complicado, é o mais 
complexo, a construção de um contexto histórico, de uma continuidade, de uma permanência, de uma consequência, essa é a maior dificuldade e é a maior preocupação, construir isso neles."

O que vemos acontecer nas falas desses professores é que suas intenções e preocupações são fundamentadas e convenientes, porém, se compararmos às respostas da primeira pergunta, há uma realidade que não condiz com as expectativas e preocupações desses professores. Ou seja, há um pensamento cuidadoso com relação às suas aulas, mas, ao fim, nos relatam que os alunos não os escutam e que seus maiores problemas (veremos com detalhes mais adiante) são a falta de respeito e a falta de interesse.

Esse conflito entre intenção, ação e reação é dos mais comuns na Educação, tendo em vista que, como falamos diversas vezes nesta pesquisa, a Educação trata da ordem do impossível, inscrito no discurso. Para entendermos como a transmissão funciona no olhar da Psicanálise, Mrech (2003) nos elucida:

A transmissão não é apenas um processo de comunicação. Ela remete a um outro circuito maior: o da instauração da transferência de trabalho. Ou seja, é preciso que o aluno tome em suas mãos o que aprendeu e passe a operar com aquilo. Não basta que ele fique apenas com o conteúdo ensinado. É preciso que ele estabeleça um saber a respeito do que foi ensinado. (p.8).

A autora ressalta, ainda, que "os professores não conseguem despertar esse efeito nos alunos", por vezes provocando neles apenas relutâncias (MRECH, 2003, p.8). Não se trata, nesse caso, de acusar o professor pelo fato de não desempenhar seu papel, pelo contrário, trata-se de perceber que algo de seu lugar no discurso social se perdeu e consequentemente sua função se torna difícil. Em outras palavras “[...] não há leitura direta da linguagem e da fala" (p.8), mas é esse circuito que alguns conceitos da Pedagogia tentam instaurar na sala de aula na tentativa de tornar a educação um método científico, com seus fins previamente definidos, como por exemplo, definindo o que o aluno irá saber ao fim do Ensino Fundamental.

Aquilo que será apreendido pelo aluno transborda os limites do que foi falado pelo professor - não há contornos nesse sentido. A palavra aqui deve situar-se no lugar de enigma para o aluno e acreditamos que é este posto de enigma da palavra que está sendo esvaziado a ponto dos professores não conseguirem impactar os alunos, há um muro que os separa.

É possível notar que o professor tem a preocupação de saber se o aluno está entendendo o que ele está falando. Perguntamo-nos se essa deveria realmente ser uma preocupação do professor, pois ela se encaminha em um sentido Simbólico do ato de educar, ou seja, fixa-se em como a palavra do professor chega ao aluno e credita em sua fala a 
possibilidade de fazer o aluno entender. Ainda, em outras palavras, habita um pensamento inerente à sua função de que quanto melhor ou mais detalhada for a explicação do professor (ou quanto mais souber como a criança aprende) maiores as possibilidades de o aluno entender e aprender a disciplina.

Por esse motivo, a fala do professor Ricardo aponta em outra direção, pois esse professor percebe que os têm atentos por suas intervenções, perguntas, colocações. Ou seja, no momento em que estão tecendo laços com o saber, estão, portanto, criando a partir do conteúdo. O conteúdo passa por eles e produz algo, fazendo com que o aluno opere com aquelas informações, criando o novo.

- TERCEIRA PERGUNTA: Até que ponto você considera que seus alunos te escutam? Em quais ocasiões? Em que outras isso não acontece?

A terceira pergunta de nossa pesquisa surgiu a partir da leitura do, já comentado, livro de Dufour A arte de reduzir as cabeças (2005a), no qual, sob determinadas circunstâncias, denuncia que os alunos não escutam mais, sugerindo a hipótese de que se eles não escutam mais também não falam mais. No entanto, esse "não falar" não se refere ao fato de não se comunicarem, pelo contrário, nas entrevistas, os professores reclamam do excesso de conversas paralelas em suas aulas. O próprio autor explica o que quis dizer com essa hipótese. Eles não escutam “[...] no sentido em que doravante eles sentem a maior dificuldade em se integrar no fio de um discurso que distribui alternativamente e imperativamente cada um em seu lugar: aquele que fala e aquele que escuta" (p.134). Entendemos que esses lugares no discurso estejam suspensos hoje, já que foi instaurado um princípio de equidade entre o professor e o aluno que, por sua vez, anula a palavra do professor como aquela que traz o enigma. Mrech (2003) esclarece uma questão significativa para entender essa reflexão, dizendo que "O discurso de cada profissão estrutura simbólica e imaginariamente a ação de seus praticantes" (p.14). Nesse sentido, a ação do professor é pautada no que o discurso sobre sua profissão estrutura para ele, fundamentado no discurso da ciência. Se hoje vivemos o discurso da igualdade, da consideração da opinião e conhecimento prévio do aluno, a ação do professor tende, muito provavelmente, a refletir essa posição. Evocamos, com isso, o desaparecimento dos limites e, como consequência, fica faltando aquilo que constitui a autoridade, é como se esta não tivesse mais lugar.

Enxergamos na hipótese de Dufour (2005a) um indicativo de como o sujeito funciona hoje, pois poderíamos dizer que estabelecer "lugares de discurso" vem sendo uma atitude cada vez mais escassa em nossos tempos. O que acontece dentro da escola nada mais é do que um reflexo mais preciso do que ocorre na contemporaneidade e suas vicissitudes; 
demonstramos isso ao resgatar as reflexões de caráter sociológico de Freud e Arendt sobre o funcionamento da modernidade tardia. Dizemos mais preciso porque talvez, na escola, por se tratar da educação de crianças, a crise fique mais evidente, já que é onde a herança dos adultos é transferida aos mais novos.

O relato da professora Carla reflete essa situação: "eles não escutam, isso é básico, eles não escutam. Sétimo, oitavo e nono que são as fases finais também, a questão do escutar é muito complicado. É muito complicada, então a sensação mesmo é de que eles não escutam nada do que você fala, tanto que você acaba de explicar a atividade, pede para eles fazerem, eles falam que não entenderam, que você não explicou. Você acabou de explicar e não entenderam. É possível através da fala desta professora de 33 anos que exerce a profissão há 11 anos percebermos a angústia de grande parte dos professores: testemunhar que sua palavra não possui mais peso frente aos alunos. Ressaltemos a diferença entre uma análise que prioriza a ideia de que os alunos estão cansados da escola e esta não serve mais para eles e a nossa: tecemos uma reflexão acerca do peso da palavra do professor hoje, que por diversas circunstâncias (declínio da autoridade, influência da tecnologia no mercado neoliberal, globalização, discurso técnico-científico, enfim, outras formas de se relacionar com o mundo) não possui mais o lugar daquela que deve ser ouvida. Dufour (2005a) alertou que muitos não foram preparados para estar nessa posição de alunos - hipótese na qual somos cuidadosos em explorar para não cairmos no engodo de uma resposta que fecha o circuito de repensar a Educação e define que as crianças não podem mais ser ensinadas. Não é isso que pretendemos; muito pelo contrário, estamos nesta pesquisa abrindo possibilidades para repensarmos a crise pela qual a educação passa.

Assistimos, por meio das falas desses professores, a solidão a que são jogados, já que a educação e os professores ocuparam o lugar de redentores dos males do mundo. Esse de fato é um peso muito grande, que evidentemente não caberia somente aos professores, mas é o que mais uma vez os discursos acerca do professor e da educação produzem no imaginário social. Vejamos o relato do professor Bruno: 'você se vê na seguinte situação: ou você tenta fazer com que o aluno mude de postura ou você vê que não conseguiu de forma alguma, aí infelizmente, você tem que tomar outras atitudes, tá, a última delas é tirá-lo da sala, tentar ainda conversar com ele fora da sala, se você vê que não teve jeito mesmo, chamar a direção ou a coordenação para tentar intermediar a relação professor-aluno”. A solidão sobre a qual articulamos se enreda no momento em que ouvimos este professor dizer: você se vê na seguinte situação... Ao olhar para sua turma em um momento de indisciplina muitas vezes os professores parecem "se ver" sem saída, pois como nos relata Bruno após se utilizar de todos 
os seus recursos para que o aluno lhe empreste os ouvidos e nenhuma delas funcionar, passa a ser preciso chamar um outro da escola para ajudar, como disse o próprio professor a intermediar a relação professor-aluno, ou seja, entrar no meio dessa "relação" e assumir alguma parte de sua incumbência tão pesada, o que sabemos, raras vezes é eficaz.

Algumas falas nos chamaram a atenção por se repetirem diversas vezes, ecoando com a teoria que desvendamos em Dufour (2005a), no momento em que destaca a característica do funcionamento prazeroso da educação. Selecionamos trechos que a nosso ver indicam essa tendência dos alunos e a percepção dos professores: "eles me escutam mais quando o assunto é algo de muito interesse pra eles, né, para falar sobre música, sobre os jogos, sobre celulares, sobre... enfim, coisas que são pertinentes ao universo deles. Só que na escola, a gente não consegue tratar só disso [...] quando a gente vai falar sobre esse conteúdo, (o próprio da escola, das disciplinas) aí eles se tornam apáticos. Você tá aqui na frente, olha para sala de aula e não tem ninguém olhando pra você, você tá falando só com as paredes”. (Manuela); "todos, independente da idade, eles te ouvem na maior parte... assim, a princípio, desde que seja feito o que eles querem” (Maria); "tem aqueles alunos que são... que já vêm pra escola sem a intenção de querer aprender. Então, eles acabam atrapalhando” (Bruno).

Devido à frequência com que esses discursos vêm à tona nas entrevistas poderíamos chamá-lo de um sintoma na Educação. Sobre isso Mrech (2005) pontua que "[...] há um sujeito que se encontra satisfeito com aquilo que ele já sabe. Ele não quer aprender o novo.” (p.155). Esse sujeito que não quer aprender o novo, poderia ser pensado como aquele que está em um lugar no qual evita elaborar psiquicamente a informação oferecida pelo professor. Estaria assim tomado por esse sintoma social da felicidade constante.

Aprender o novo não será necessariamente prazeroso; poderíamos inclusive afirmar o contrário, a elaboração psíquica que a aprendizagem requer é sofrida, neste caso, tanto para um professor quanto para um aluno. Ninguém parece contar aos alunos esta parte, já que a educação hoje além de ser a redentora dos males do mundo ainda deve ser prazerosa, ou seja, os alunos não devem somente aprender, mas também aprender com prazer, com facilidade, o que na maioria das vezes não é possível. A noção de prazer imposta à escola parece estar ligada ao prazer relativo, ao consumismo, às viagens e à comida. Não queremos dizer que aprender não possa ser prazeroso, porém, muitas vezes, não é todo seu processo que é prazeroso, afinal faz parte de uma elaboração, em outras palavras "não se compra pronto" o conhecimento e a aprendizagem como os produtos do mercado. Não se fica como mero espectador, como em uma viagem ou ainda não basta engolir o conhecimento como uma 
degustação gastronômica. Enfim, de nada adianta tentar encaixar a escola nesse circuito de satisfação imediata do desejo.

Essa satisfação imediata refere-se a uma satisfação narcísica não mais relativa a uma representação, mas sim do objeto em si, aquele que pode estar presente na realidade. Tal articulação nos faz retomar a prevalência do registro do Imaginário calcado por Lacan, no qual não há simbolização, há apenas referências a uma relação de completude entre sujeito e objeto.

A aprendizagem direta dos caminhos de acesso, tanto ao objeto quanto a si mesmo, deve assegurar uma trajetória quase feliz e sem complicações. É verdade que essa relação com um sistema em que o limite assim se encontra suspenso simplifica consideravelmente a tarefa psíquica de cada um" (MELMAN, 2008, p.28).

Por que deveriam então os alunos escutar os professores, já que o que oferecem é da ordem de um esforço, uma reelaboração dolorosa, se por sua vez foram preparados para ter acesso aos objetos sem esses percalços? Fato é que não há nada que sustente o contrário, ou seja, não há nada que permita ao professor opor-se a esse funcionamento prazeroso ao qual a educação o força a passar para o ato educativo. Há, na contemporaneidade, um "direito adquirido" de todos os sujeitos de legitimar seu desejo, não haveria portanto motivos para se opor a nenhuma escolha; isso nos parece um indício do esvaziamento da autoridade. Melman falou a esse respeito, afirmando que não há limites para o prazer e portanto “[...] para ter acesso à satisfação, não é mais necessário passar pelo disfuncionamento [...] não é mais inevitável usar esses trajetos complexos e dolorosos [...]” (MELMAN, 2008, P.28). Por outro lado o autor alerta para um "gozo artificial” gerado por essa situação.

Selecionamos algumas falas nas quais os professores declaram sobre as situações em que percebem que seus alunos os escutam: "Eu vejo que eles estão me escutando quando eles passam a questionar alguma coisa que eu falei, então, eles pensaram, sintetizaram a informação, trabalharam com ela e aí, encontraram algum ponto de talvez incoerência, ou talvez que eles não entenderam bem, então, a gente quando é questionado, sabe que eles estão prestando atenção." (Ricardo); "Eu vou escutar, porque senão, eu não vou descer para quadra”, "Eu vou obedecer, porque senão, não tenho a aula prática”, então, a princípio, o primeiro momento é esse. Ai, eu vou escutar, né? Mas depois, a gente desenvolve, mas no começo é assim (Maria); Eles escutam assim, como eu falei antes, quando eu tenho que dar o comando da atividade, eu consigo manter uma certa atenção deles, só que eu não posso ficar 
falando muito(Gustavo); nunca espero 100\%, já é uma coisa que até se você parar para pensar, desanima, porque... mas não espero que 100\% deles me escutem. (Felipe).

E outras nas quais constatam que seus alunos não os escutam: "Eu vejo quando eles não estão prestando atenção quando eles estão conversando, distraídos, com fone, dando as costas, saindo, fogem da sala [...]quando eles promovem indisciplina dentro da sala." (Ricardo);” eles não escutam quando a proposta, às vezes, não interessa pra eles, eles acham que aquilo não vai ser legal ou pela dificuldade de alguns alunos" (Gustavo); se tá desinteressante, é porque ou tá muito fácil ou tá muito longe do que eles conseguiriam ver, imaginar ou fazer, né?" (Felipe).

- QUARTA PERGUNTA: O que você nomearia como a maior dificuldade de um professor de Ensino Fundamental, hoje?

Algumas respostas foram semelhantes para essa pergunta. Denunciaram uma situação importante nas salas de aula brasileiras: "A indisciplina é a maior dificuldade. A falta de respeito, de compromisso, de comprometimento, eles não... para eles, parece que a educação não tem valor nenhum." (Carla) São tantas dificuldades... eu acho que é o interesse do aluno." (Victória). Talvez que ele te escute e entenda, né, que ele pare pra te ouvir que é algo importante (Maria); hoje, a maior dificuldade é lidar com a falta de respeito dos alunos. (Gustavo); Maior dificuldade? É a falta de educação dos alunos. Falta de respeito, assim, de interesse (Felipe). Podemos inferir dessas falas que o esvaziamento da autoridade, e em algumas falas, o esvaziamento da autoridade da palavra, mais especificamente, ficam evidentes. O que os professores declaram como falta de respeito, indisciplina, falta de interesse e etc. nos parecem ser algumas das facetas que a autoridade - despedaçada em nossos dias - do professor, na sala de aula, pontualmente em seu dia-a-dia vem sofrendo em seu silêncio, em sua solidão. O direito de falar, aqui, está impedido.

Nos chama a atenção o número de vezes na qual a indisciplina, o desrespeito e outros sinônimos apareceram nas respostas dos professores. Isso nos assusta, pois há uma característica das entrevistas que não pode ser demonstrada em forma de escrita: a rapidez, a certeza e a revolta dos professores ao responderem esta pergunta especificamente.

Alguns dos professores comentaram sobre o comportamento de seus alunos na escola como um reflexo do que provavelmente acontece em suas casas, com suas famílias: "tem muito aluno que não te obedece, que quer te enfrentar, porque ele tá vendo na frente dele uma autoridade, não o professor. Então, talvez, ele tenha uma situação assim, de que ele não tem abertura para falar, ele briga com isso em casa e ele chega aqui, ele quer fazer a mesma coisa. Pra mim, a maior dificuldade não é nem pedagógica, eu acho que nisso, eu consigo me 
resolver, o problema é a falta de respeito, mesmo" (Gustavo). "Eles não entendem o porquêe da educação, o porquê de estar na escola, eles acham que eles vêm porque são obrigados pelos pais e só por isso que eles vêm. Então, eles não têm comprometimento nenhum." (Carla). Uma reflexão mais atenta nos apontaria novamente a escola e os professores deslocados de sua função na civilização, o próprio indício do esvaziamento da autoridade da palavra do professor, ou seja, qual peso ainda poderia ter a palavra de um professor, os conhecimentos que ele pode passar se os alunos não depositam um "suposto-saber" na fala destes professores ou na instituição escolar? Depositar um suposto-saber seria uma das formas de se autorizar a palavra dos professores, porém não como aquela que tudo pode responder como em um discurso totalizante (o que muitas vezes o discurso da ciência deposita na educação).

Ao mesmo tempo em que se deve esvaziar a autoridade da palavra de sua função exclusivamente Simbólica, não se pode desconsiderar sua função civilizadora. Ou seja, esvaziá-la da função exclusivamente Simbólica significa permitir a entrada do Real na educação, permitir que o saber não-sabido exista e que não podemos dar conta de tudo por meio da palavra - esse seria o lado benéfico do esvaziamento da autoridade da palavra, sobre o qual nos perguntávamos na introdução desta pesquisa. Por outro lado, a palavra totalmente esvaziada fica sem enigma, sem peso, nesse caso nos vemos em outro extremo nocivo para a educação.

É interessante perceber que o professor Gustavo capta uma posição preestabelecida dos alunos em relação aos professores: que eles representam uma autoridade a ser derrubada “[...] quer te enfrentar, porque ele tá vendo na frente dele uma autoridade, não o professor". Nos permitimos retomar um trecho da entrevista com a professora Carla (respondendo a outra pergunta) que também aponta esse enfrentamento que os alunos se veem diante do lugar do professor: "[...] eles acham que ninguém manda neles, então: 'não preciso sentar, porque você não manda em mim', então é muito complicada essa questão da conversa com eles, porque eles acham que você tá afrontando eles o tempo todo" (Carla). Ponderemos o outro lado dessas falas: é de fato um tanto quanto inerente ao comportamento adolescente essa forma questionadora de encarar o mundo e as regras dos mais velhos, mas o que nos chama a atenção nesse comportamento, segundo nossas leituras e as falas desses professores, é que o que fica deste questionamento (que poderia ser sadio para criar o novo) é apenas apatia discente, isto é, não há um encontro com o Real que o mova e tire desse circuito dual entre desejo e legitimação do desejo. Poderíamos dizer simplificadamente que o aluno não escuta essa possibilidade nas palavras do professor, ele não engancha e isso se torna um desafio para 
os professores: “Às vezes, ele não quer ouvir, como que eu vou atingir esse aluno que ele precisa aprender o que é realmente importante? Então, eu acho que esse é um desafio, como aprende e como escuta." (Maria).

Alguns relatos mostraram respostas diferentes dessas, chamando a atenção para outras questões importantes na educação: "Mudar a imagem perante alunos e pais de alunos que a escola pública, ela não oferece boa qualidade. Primeira coisa. Isso aí foi um trabalho feito durante muitos anos denegrindo a imagem da escola pública, porque se a gente for analisar, o currículo é o mesmo, se o currículo é o mesmo, onde que tá a diferença entre a pública e a particular? E aí, a gente procura passar para os alunos que o diferencial, na verdade, são eles, que quem faz a escola é o aluno, que ele tem que procurar ter uma postura diferente do que a maioria tem e que é o futuro dele que tá em jogo. Não é que ter um diploma vai garantir, mas o conhecimento, ele ainda garante uma qualidade de vida melhor, em termos profissionais, do que o que não tem conhecimento nenhum" (Bruno). Esse professor aborda um assunto delicado sobre educação ao dizer que não há muitos esforços para mudar a imagem da escola pública, e, se pensarmos embasados na teoria aqui apresentada, já que Dufour alertou para uma essência mercadológica em tudo que vivemos hoje, por quais razões as empresas e o poder público iriam querer elevar a imagem da escola pública? Isso talvez só tire o poder de alguns e bem sabemos que nossa sociedade funciona no circuito do prazer e do consumo. Sobre este assunto seria necessário um estudo mais aprofundado, já que envereda por outros caminhos diferentes dos quais estamos refletindo.

Outra fala que nos surpreendeu bastante pelo fato de abordar as dificuldades do professor de outro ângulo é a seguinte: "Eu acho que a escola, ela... essa questão da universalização do ensino, sabe? Não é que o aluno não mereça ter acesso à educação, não é isso, mas nem todos os alunos querem estar dentro da sala de aula, nem todos os alunos têm essa vocação para estar dentro da sala de aula. Eu acho que a escola, ela precisa existir para aqueles que querem estudar. Deveria ter um outro mecanismo para atender esses outros alunos que não querem. Por exemplo, quando eu estudava, tinham vários alunos que não queriam, eles iam para o Paula Souza, né, que eram as escolas técnicas e ali, eles tinham outras atividades e eram felizes, eram bem sucedidos, funcionava. Eu, depois, quando eu fui... que eu me formei, eu fui fazer um estágio, inclusive numa dessas escolas, a aula fluía muito bem, né, os alunos participavam porque depois, eles sabiam que eles iam para a aula prática e que aquilo tinha sentido, significado para a vida deles, o que hoje... o que eu percebo hoje é que esses alunos não conseguem ver significado, não faz sentido da realidade que eles vivem para dentro de uma sala de aula, tendo que estudar o século XII, a formação 
do Império Carolíngio, sei lá, não entra na cabeça dele, porque a realidade dele é completamente diferente. Então, a maior dificuldade é essa, você dar sentido para o cara dentro da escola, né, criar um significado para ele e infelizmente, não tem. E isso prejudica aquele que quer estar aqui, que quer aprender, que se dedica, sabe? (Victória). A universalização do ensino é um ponto bastante interessante para entender a crise na educação. Fizemos esse movimento esclarecendo sobre o nascimento da escola moderna (laica, pública, gratuita e para todos). Ouvimos na fala desta professora uma tendência comum hoje vista nas escolas particulares de "tematizar" os tipos de escola, por exemplo escolas voltadas para o ensino de artes, escolas que priorizam o vestibular, o treino, escolas mais conservadoras, acadêmicas e etc.

O desabafo que nos traz essa professora nos leva a crer que a universalização da educação se trata também de uma herança da tradição positivista, que traduz a exaltação que o avanço da ciência provocou no mundo como uma tecnologia capaz de revolucioná-lo. Naquele momento forjou-se uma concepção instrumental da educação que pretendia "ensinar tudo a todos" na empreitada especialmente conhecida da obra de Comênio publicada em 1657: Didática Magna: Tratado da Arte Universal de Ensinar tudo a Todos. Inaugurava-se uma possibilidade de homogeneização na educação pautada no discurso da ciência:

[...] se a concepção utilizada para fazer ciência equivale a produzir tecnologia utilitária e instrumental, em Comênio esta tecnologia será metodológica e referir-se-á ao longo e impossível sonho de dominar a natureza humana - se é que ela existe - para ensinar tudo, a todos. (CAMARGO, 2006, p.56).

Todas essas falas nos fazem retornar ao incômodo inicial que gerou a inquietação e o desejo pela pesquisa, a essência romântica inserida na educação, sobre a qual este último relato da professora Victória nos faz ver - quando ela se dá conta do encontro com o Real, o encontro com a criança real que muitas vezes não consegue se adequar aos moldes da escola e à idealização do professor. A maioria das respostas nos indicou que há um incômodo gerado por esse (des)encontro, que muitas vezes é traduzido pelo esvaziamento da autoridade da palavra. Calixto traduz esse incômodo para o âmbito do encontro da palavra: "Percebo o aluno de um lugar que traz na sua palavra o sujeito que não esperamos e uma demanda maior que conteúdos e programas previamente preparados" (CALIXTO, 2007, p.221). Denuncia, portanto, esse choque do professor com o aluno real, não o aluno ideal que se imagina poder criar. Esse poderia ser um dos motivos pelo qual a escola não consegue lidar bem com este novo sujeito e nova forma de ser no laço social, nova forma de discurso na qual há um 
privilegiamento do registro Imaginário, que remete aos objetos, numa relação toda, que quer significar tudo. Esse movimento parece funcionar para o mercado de produtos, mas ao que toca o âmbito de pessoas e no caso da escola, pessoas em formação, esse formato não gera criação, reflexão - gera sim apatia à escola (que poderia dizer ser o sintoma mais evidente e preocupante da crise).

A próxima pergunta, indica algo acerca da imagem que os professores criam deles mesmos frente aos alunos, enfim, como imaginam serem vistos por eles.

- QUINTA PERGUNTA: De que maneira você acha que os alunos veem você?

A primeira análise que nos salta aos olhos mostra os deslocamentos que a posição do professor pode possibilitar, já que encontra, no discurso do senso comum, atribuições das mais diferentes e, como já vimos em relatos anteriores, os professores percebem uma precariedade da relação e das conversas dos alunos no campo familiar. Testemunhemos uma resposta intrigante: "alguns me veem como o pai que não têm, alguns me veem como um amigo, que eles precisam contar coisas. Alguns me veem como o professor que realmente tá ensinando alguma coisa que tá fazendo diferença para [...]Eu acho que eles me veem como várias coisas, mas como professor de verdade, acho que a minoria é que vê, entendeu? Até pelas relações familiares de hoje em dia por serem muito diferentes, então eu acabo sendo um pouco de tudo: ou o pai, ou a mãe, ou o amigo e talvez, lá embaixo, eu sou o professor deles (risos)." (Gustavo). O professor relata que uma das últimas formas que sente ser olhado pelos alunos é como professor. Quanto essa situação nos permite entender o lugar da palavra do professor hoje, ou a própria autoridade de sua palavra? Podemos pensar que o panorama trazido por nossa construção teórica mostra-nos um lugar, que sobra para o professor, muito difícil de ser tomado como discurso por eles próprios. Ora o mestre inatingível autoritário, ora o mediador do conhecimento, enaltecendo uma imagem de "o professor" que na verdade não existe. Fica portanto menos complexo colocar-se diante do aluno (estabelecer a transferência) por intermédio do semblante do pai, do amigo, da mãe e, a partir daí, estabelecer algum enganche de sua palavra. Leny Mrech (2003) nos envolve mais ainda nestas reflexões, dizendo:

Assim como não se sabe quem é o aluno, a Pedagogia também não tem claro quem é o professor que trabalha com o aluno. Geralmente há uma redução do professor a um indivíduo concreto chamado "professor". Mas será que da mesma forma que ocorre com a criança nós aqui também não estamos frente a uma enorme confusão? Será que também nós não nos enganamos? Será 
que o professor refere-se a uma pessoa concreta ou a um lugar no discurso? (p.7-8).

Podemos afirmar que o professor é um lugar no discurso, baseados em toda teoria que costuramos, por esse motivo é importante entender o esvaziamento da autoridade da palavra, pois esse esvaziamento indica uma mudança desse lugar que o professor ocupa no discurso.

Esses lugares que o professor ocupa no imaginário e no discurso social refletem sobremaneira na palavra do professor e na escuta dessa palavra pelos alunos. Apesar de demonstrarmos nesta pesquisa o iminente declínio da autoridade do professor, este mesmo professor nos relatou uma outra posição interessante, pois retoma a "corda bamba" na qual as ações dos professores são colocadas (ora autoritária, ora igualitária): "Eles não veem a gente como uma pessoa que tá ali para tentar ensinar alguma coisa para a vida deles. Eu acho que eles veem a gente como autoridade que tenta manter um controle. Eles ficam tentando... muitos tentam desafiar essa autoridade, mesmo às vezes, sem um motivo real. Então por mais... tem gente que não sabe lidar com a abertura para o diálogo, então eles acham que isso é perda de tempo, não é aula. E se você, por exemplo, dá aula de fato, alguns também reclamam, porque você tá dando aula. Na verdade, eles querem não fazer nada muitas vezes. Então, você tem que lidar com esses dois extremos, os dois lados da mesma moeda." (Gustavo). A professora Manuela também relata esse impasse: “Então, eu tento ser com eles o mais humana possível para que eles me vejam dessa forma, mas eu também acho que não atinge $100 \%$ dos alunos, alguns devem me ver como uma bruxa, alguma coisa assim, alguém que está para impor disciplina, sei lá”. (Manuela)

Observamos que alguns professores alegam não serem vistos de uma maneira agradável pelos alunos, como mostram estes trechos: "Neste momento eu tenho recebido muitos elogios: bruxa (risos), de uma forma não muito... agora, agora, eles têm... eles me acham exigente, pronto! É isso" (Victória). "Quem não me conhece, é a primeira vez que está tendo aula comigo, eu acho que me vê bem chato, porque eu cobro muita coisa”. (Felipe). Há um acontecimento aparentemente importante para construir em si mesmos a imagem que têm diante do aluno, o reconhecimento. "Alguns me veem como o professor que realmente tá ensinando alguma coisa que tá fazendo diferença para eles quando eles saem, voltam e conversam: 'Olha, aquilo que você me ensinou, eu aprendi em tal lugar e eu vi novamente, e consegui me dar muito bem nisso'. (Gustavo)". "Hoje é aula na sala? Hoje é aula teórica ou é prática? A gente vai escrever? A gente vai ler?", então assim, eu vejo que eles já encaram com um pouquinho mais de importância, não só uma aula recreativa, eles estão começando essa conscientização, tá pouquinho, ainda, passinho... trabalhinho de 
formiguinha, mas eu acho que já é um avanço(Maria). "Eles me citaram na formatura como alguém que tinha feito... fez com que eles estudassem, então assim, naquele momento em que eu estava na sala de aula, foi terrível, foi frustrante, foi muito sofrido, mas no processo de amadurecimento desses alunos, eles entenderam aquilo que eu falei.” (Victória).

Baseada nos questionamentos acerca do lugar do professor no imaginário social, nos elucida Mrech:

Merleau-Ponty assinala que a Pedagogia é a imagem que o adulto faz da criança, uma imagem que o professor faz do aluno. Uma imagem que revela a percepção que o adulto teve da criança, e que se encontra fundamentada na relação especular, isto é, na forma como o professor se olhou através do aluno. (2003, p.11).

Por esse motivo, no início das entrevistas, tomamos o cuidado de fazer perguntas de cunho pessoal aos professores, pois, muito provavelmente, são as lembranças que têm de como eram escutados quando crianças que influenciam a imagem de criança que projetam em seus alunos. Isso é um fato inerente à condição humana, a saber, a diferença geracional. É esse encontro do adulto (e suas reminiscências) com a criança - do velho com o novo - que gera a crise inevitável, o (des)encontro. Porém, o que ressaltamos nessa análise é que a referida crise deveria impulsionar a criação do novo através do encontro com a palavra e ao que nos parece o esvaziamento da autoridade da palavra marca um engessamento da posição da crise e somente dela. Fica, assim, girando em torno da crise sem que sua palavra enganche no aluno e sem que possa trabalhar com a palavra, produzindo um saber que é seu. 


\section{CONSIDERAÇÕES FINAIS}

Nossa pesquisa caminhou no sentido de refletir a respeito de dois questionamentos centrais: o esvaziamento da autoridade da palavra poderia afetar o esvaziamento do enigma que permite a aprendizagem? As mudanças na aprendizagem, que às vistas da contemporaneidade parecem ser inevitáveis, não podem vir a ser benéficas de alguma forma para os sujeitos contemporâneos?

O esvaziamento da autoridade da palavra tornou-se o nosso próprio enigma durante a pesquisa, pois, ao mesmo tempo em que corria o risco de ser entendido e agregado a um discurso hegemônico da Pedagogia (e com isso embarcar no tom de denúncia); indicava-nos posições muito diferentes e delicadas acerca do peso da palavra do professor nas escolas de hoje, assim como a influência da forma como os sujeitos se relacionam (priorizando a relação professor - aluno). Foi por este segundo caminho que insistimos em traçar nossa empreitada, sempre ressignificando nosso entendimento do esvaziamento da autoridade da palavra.

A substituição da palavra perda pela palavra esvaziamento de início nos indicou um caminho: em se tratando de uma reflexão psicanalítica a escolha das palavras deve ser feita com cuidado. As palavras oferecem inevitavelmente e imediatamente imagens e sentidos aos leitores e pretendemos o contrário: desconstruir tais imagens a todo tempo, tratando a palavra como algo estruturalmente mutável no campo da cultura, algo que não se perde, mas, que de tempos em tempos pode esvaziar-se, assim como pode tornar-se plena.

Detectar um problema na Educação e oferecer soluções com certeza não se encontrava em nossos objetivos, porque entendemos que não há resposta completa, não é possível, ao que concerne à Educação, oferecermos uma única solução para todos, exatamente por ser um campo não capturável e estar calcada em uma região do impossível. Não podemos saber de antemão quais efeitos as palavras dos professores e seu ensino terão. Os sujeitos não se constituem da mesma forma, por este motivo as palavras os atingem de diversas maneiras, isso é o que nos faz humanos e permite a introdução sempre inesperada do encontro com o Real que nos movimenta. Finalmente, é importante lembrar, não oferecemos a possibilidade de uma "Pedagogia psicanalítica", a Psicanálise apenas pode nos fazer refletir sobre como lidamos com os inevitáveis erros e angústias que a Educação nos proporciona. Mesmo não sendo possível oferecer soluções, poderíamos dizer que nos é legítimo tirar conclusões ou possibilidades de pensar a crise na educação hoje pois são as próprias impossibilidades de sentido que a palavra e a educação possuem que nos permitiram defender uma hipótese, refletir e entender, sob uma ótica da Psicanálise a crise que afeta os professores, os alunos e a 
escola e consequentemente sua palavra, assim como - não poderia deixar de ser - todos os sujeitos no contemporâneo. Não podemos precisar como a palavra do professor chega ao aluno, mas podemos, por meio de análises de queixas e angústias, perceber que algo relativo à palavra mudou e com isso tecer uma reflexão acerca do que motiva a engrenagem dessas mudanças.

Sendo assim, conseguimos expressar o esvaziamento da autoridade da palavra, nesta pesquisa, em diversas frentes. Inicialmente, tal esvaziamento apresenta-se como um recorte do que pudemos estudar na teoria de Freud sobre o mal-estar na civilização. Esse conjunto de reflexões sobre como é ser sujeito na vida moderna sustentou e permitiu um embasamento psicanalítico (e poderíamos dizer, também sociológico) que inaugurou um modo de pensar sobre a vida e as relações desses sujeitos com suas aflições cotidianas. O que Freud (1996) nomeou, inicialmente, como uma investigação sobre a felicidade, se configuraria como uma demonstração da insatisfação estrutural que persegue o homem a partir do momento em que se inaugura para ele o campo do Outro, ou seja o campo social em sua dimensão Simbólica, da cultura e da linguagem. A investigação que apontava a civilização como aquela que prejudica a realização dos instintos do homem já não se sustentaria da forma que seu autor havia pensado, pois, ao fim, ele aponta para um mal-estar que funda a civilização, ou seja, que é estrutural, portanto colado a ela.

Dessa forma, desenhamos algumas bordas para nossa noção de incômodo na civilização: este sempre irá acontecer à medida que todos os dias entramos em contato com uma realidade que nos organiza, a saber, a realidade da decepção. Por outro lado, isso não significa que o esvaziamento da autoridade da palavra deva ser associado a um estado natural e irremediável de nossa contemporaneidade. Há algo nesse incômodo, na angústia gerada pelo esvaziamento que precisamos entrar em contato, o que a nosso ver é o que mais tem se evitado fazer no âmbito escolar.

Retomando nossa noção de decepção que organiza a realidade (e por consequência sabemos que não estamos sonhando ou experimentando a felicidade plena), algumas teorias e metodologias que normalmente se traduzem em discursos do senso comum pretendem mascarar os problemas da Educação com soluções prontas e isso tira de cena o professor como sujeito, pois é como se a ele tivessem sido ofertadas todas as possibilidades de fazer a Educação "dar certo" e, se isso não aconteceu, é provavelmente algum erro em sua conduta, carece de formação ou cursos de "reciclagem"; tenta com isso tornar a realidade do professor menos decepcionante com soluções paliativas. No entanto, acaba por afirmar sua condição depreciada. 
Há um outro recorte sobre o esvaziamento da autoridade da palavra que encontramos fundamentado na teoria formulada por Hannah Arendt (2013) a respeito da crise na Educação. Dizemos que se trata novamente de um recorte, pois a noção que Freud nos propôs sobre o mal-estar na civilização nos embasou para pensar o sujeito que vive a modernidade, já o pensamento de Arendt sobre a crise na Educação, seria uma fotografia mais focada das razões (calcadas por nós no pensamento de Freud) para tal crise se configurar como um nó na civilização, especificamente no campo educativo. Entendemos a crise como um evento pontual, que acontece de tempos em tempos na organização social e que vem para estremecer algumas condutas dos sujeitos quando algo no discurso social vem a mudar.

A autora aponta para uma necessidade iminente de desfazer-se de um Velho Mundo e inaugurar um Novo Mundo. Para isso, depositou-se nas crianças essa possibilidade. Dito de outra forma, a Educação se volta para o esquecimento do modo de funcionar do velho mundo, para entregar às crianças a oportunidade de fundar uma nova ordem. Nesse mundo, comum a todos nós, o nascimento dos novos sempre gera uma crise, e do encontro com essa desproporção é que surge a possibilidade do novo, porém se os adultos se retiram da função de apresentar o mundo (se sua palavra já não exerce mais essa função) - ou seja, a função de educar - algo se perde e corremos o risco de fundar uma ordem "morta" a princípio. Por esse motivo, Arendt (2013) afirma que a essência da Educação é a natalidade. A tentativa de equilibrar e nivelar adultos e crianças, depositando neles o mesmo peso de palavra e de responsabilidade sobre o mundo, gera um "além da crise" (já que consideramos a crise como uma oportunidade para rever paradigmas), que em nossa pesquisa é entendida como o esvaziamento da autoridade da palavra dos professores.

Para esmiuçar esse "além da crise" na educação e também na crise da cultura - pois uma é somente outro contexto da outra - mergulhamos na Psicanálise para entender sobre qual palavra estamos falando e qual esvaziamento.

A palavra sobre a qual pautamos nossa pesquisa é a palavra por trás da palavra dita, está relacionada com uma noção de enigma, de ambiguidade e de miragem que se esconde em seu avesso. Lacan (1998) afirma que não há fala sem resposta, mesmo que só haja o silêncio, este já é uma resposta, o que nos leva a crer que se há algo da palavra do professor que não mais engancha no aluno, esse silêncio dos alunos, no caso, poderia ser entendido como as dificuldades de aprendizagem, em uma forma de recusa à palavra, pois a palavra do professor não encerra peso no discurso, por ser organizado pelas modulações do discurso da ciência, em particular o discurso técnico-científico. 
Quando nos perguntamos se o esvaziamento da autoridade da palavra poderia afetar o esvaziamento do enigma que permite a aprendizagem, tal indagação levou-nos a formar uma visão: de que a palavra do professor vem sendo esvaziada de enigma pelos diversos acontecimentos que marcaram a Educação (em particular no que toca a autoridade) e pelos que marcaram mudanças no discurso como sendo aquele que produz laço social, a saber, o discurso da ciência, a escola moderna e a entrada dos saberes "psi" na Educação. A consequência disso é que esses novos discursos inauguraram um novo modo de funcionar, criando um sujeito que gira em torno de algo que o paralisa e de onde ele não consegue sair: o excesso e o gozo em um sentido mercadológico.

O sujeito barrado é aquele dividido pela linguagem (pelo grande Outro), ou seja, pela cultura. Em se tratando de uma mudança na palavra, é possível pensarmos afinados com Dufour (2005a) em sujeitos "mal-barrados", que ficam à mercê do gozo. Ficam, assim, presos em um circuito que não deixa a palavra do outro atingi-los. Mesmo que toda palavra tenha um efeito sobre o outro, para esses alunos só produz efeito em si mesmos, quando essa palavra faz eco com seu gozo. Pudemos escutar isso nas entrevistas quando quase todos os professores, em algum momento, comentaram que os alunos só lhes dão atenção quando falam algo que faz parte da vida deles ou que eles já conhecem de alguma forma.

Há, portanto, um excesso de foco no registro Imaginário e uma precarização do corte do Simbólico que instaura a falta e, mais ainda, uma ausência de encontros com o Real (ou pelo menos de não negação do Real) tudo isso visando à felicidade plena, como já havia demonstrado Freud (1996). Por outro lado, entendemos, por esta pesquisa, que por vezes há também um privilegiamento do Simbólico como aquele que poderá significar tudo, através da palavra e esta posição também prejudica a palavra com seu caráter enigmático. Este seria o encaminhamento da resposta da segunda pergunta que guiou a pesquisa.

Novamente retornamos a Freud (1996) para entender que não há como o indivíduo experimentar uma sensação de felicidade prolongada, a decepção é necessária para organizar nossa realidade, porém, entendemos que os sujeitos são levados (pelo discurso da ciência) a acreditar que pode haver felicidade plena (querem acreditar e provar - a ciência acredita de certa forma - que existe relação sexual). É o furo causado pela linguagem que determina a não existência da relação sexual. Lacan (1992) forjou essa expressão, usada na Psicanálise para exprimir e detalhar o impossível de Freud, ou seja, ao dizer que "não existe relação sexual" Lacan anuncia o furo no Real que o sujeito experimenta toda vez que se depara com aquilo do qual não consegue dar conta no Simbólico, isto é, não consegue colocar em palavras. 
Dufour (2005a) irá entender o que chamamos de precarização do corte do Simbólico como uma função simbólica mal instalada e as consequências nas formas de simbolização, ou seja, o impedimento do sujeito se tornar falante, instalado pelo discurso- nesse caso não no sentido apenas da fala como palavra proferida, mas sim como implicação do sujeito com sua fala na construção de um enigma. Poderíamos pensar que esse mecanismo serve também para o sujeito, como ouvinte, enganchar em uma fala.

Nas entrevistas, pudemos testemunhar isso nos momentos em que os professores falavam que seus alunos não os escutam e que suas maiores dificuldades e preocupações são fazer o aluno lhes dar a oportunidade de entender o que estão falando e entender a causa da indisciplina e da falta de respeito. Há uma angústia arraigada na fala dos professores que parecem não ter mais o direito de falar. Concluímos que a autoridade da palavra seria o próprio direito de falar, como direito adquirido pelo discurso social. É do esvaziamento, portanto, do peso do discurso que sustentava o direito de fala do professor que trata aqui.

As entrevistas realizadas nesta pesquisa nos mostraram que os professores não sabem dizer por que seus alunos não os escutam, quase sempre reconhecendo apenas que "algo mudou" e que por esse motivo eles não têm autoridade, como consequência, seus alunos não os ouvem. Esse é o circuito da angústia (e do silêncio) que pudemos perceber na fala dos professores. Eles percebem que algo mudou, mas não conseguem identificar essas mudanças, de modo a poder lidar com elas. Compreender como as mudanças os afetam - tal como buscamos realizar nessa pesquisa - permite que os professores não fiquem presos ao discurso técnico científico que os excluem e os instalam no circuito da angústia que gera o silêncio. Sobre isso lembramos novamente a colocação de Mrech (2005): “[...] é fundamental que o professor se descole daquilo que a sociedade proponha para ele, atrelado a novas envolturas, a novos semblantes.” (p.154)

Para ilustrar o esvaziamento da autoridade da palavra dos professores, além das entrevistas feitas, apresentaremos uma reportagem recentemente publicada na revista Nova Escola, intitulada Fala que eu não te escuto: desvalorização profissional, competidores de outras áreas e normas inconstitucionais calam o professor no debate educacional (RATIER, 2015). A reportagem alerta para uma situação bastante comum nas pesquisas e debates do campo educativo, o professor (aquele que está na sala de aula todos os dias) raras vezes é chamado a responder, falar e discutir sobre os problemas inerentes a sua função nos textos jornalísticos que tratam da Educação; em seu lugar, geralmente são chamados economistas, psicólogos, psicopedagogos, jornalistas, entre outros. Em outras áreas do conhecimento essa situação não é comum. Médicos são chamados para falar de medicina, Engenheiros são 
chamados para falar de engenharia e assim por diante. A reportagem destaca e confirma essa situação em números:

Uma pesquisa realizada pela Agência de Notícias dos Direitos da Infância (Andi) e pelo Ministério da Educação (MEC) analisou 5.362 textos jornalísticos publicados por 57 jornais brasileiros e concluiu: os convidados a pautar na mídia o debate educacional são organizações da sociedade civil, pesquisadores ou fontes oficiais (como o próprio MEC, o Ministério Público e os Conselhos de Educação). Apenas 5,9\% das fontes ouvidas eram professores das etapas básicas de ensino. (RATIER, 2015, p.10).

Por causa desse silêncio que os professores sofrem, e que são na verdade silenciados, sua palavra perde cada vez mais peso, já que o saber do professor não é mais sequer delineável, pois se mistura a todas as outras áreas "psi” infladas mais uma vez pelo discurso técnico-científico. Essa posição do discurso da ciência o apaga e o exclui. Em outras palavras, se o professor se aceita e se vê nessa dupla posição entre o mestre encarnado que tudo pode e tudo sabe e o professor mediador, um igual perante o aluno, ou ainda como aquele que não possui saber sobre sua prática, sua palavra dificilmente chegará com algum peso frente ao aluno, pois estará preso ao que o discurso hegemônico da Pedagogia propõe para ele. O fato é que os alunos, por sua vez, também estão enredados nesse discurso, não conseguindo - como demonstrou Dufour (2005a) - estar no lugar de alunos, perceber que há o lugar do que fala e o lugar do que escuta.

Deve haver um encontro com o Real da miragem da palavra e não da palavra em si e com isso sair do privilegiamento Simbólico e Imaginário. O professor deve se haver com a educação impossível e a sociedade deve escutar mais os professores. Esta nossa reflexão refere-se à segunda pergunta que permitiu esta pesquisa: As mudanças na aprendizagem, que às vistas da contemporaneidade parecem ser inevitáveis, não podem vir a ser benéficas de alguma forma para os sujeitos contemporâneos? O benefício do esvaziamento da autoridade da palavra do professor só poderia ser assim pensado na medida em que se refere a esvaziar uma palavra "toda" para favorecer uma palavra "não-toda" na educação, permitindo, assim, que o inconsciente do professor e do aluno trabalhem para oferecer uma palavra viva e não uma palavra morta. A palavra "toda" é aquela que tudo quer significar em um processo linear de aquisição do conhecimento, no qual o professor fala e os alunos recebem essa informação visando a um fim já sabido, se refere ao "saber sabido". O esvaziamento dessa palavra pode vir a ser benéfico para os sujeitos da escola poderem lidar melhor com as vicissitudes da Educação, privilegiando um “saber não-sabido”. 
A palavra morta seria aquela que, de antemão, já está identificada, é mecânica (sem saber que o é) e se fecha em um sentido, em uma interpretação que engessa.Oferecer uma palavra viva refere-se a considerar a fala e a linguagem como encadeamento em constante movimento que sempre foge ao nosso entendimento e oferece algo da ordem do desejo, do inconsciente. Ou seja, o professor precisa estar perante os alunos movido por um desejo. $\mathrm{O}$ difícil é sustentar essa palavra frente a uma sociedade pautada no discurso da ciência, que acaba por nos envolver e a tarefa de sair desse circuito torna-se extremamente árdua para os professores. Isso acontece porque há uma confusão na qual o professor se vê: ele passa a achar ou dizem a ele que é necessário uma retomada da autoridade; então, o discurso da ciência vem atribuir força e poder para se alcançar a legitimação da autoridade que, por sua vez, fará o professor ser escutado, mas, na verdade, só faz retirar mais ainda o sujeito que ali está, pois encerra sua participação na palavra. O saber científico funcionaria como motor da solução: reformar a autoridade ou o lugar do professor na sociedade. O professor aceita essa imposição para justificar sua necessidade de domínio.

Para que os alunos se coloquem a emprestar seus ouvidos, os professores precisam "jogar a isca”, ou seja, fazer valer seu direito de falar saindo da posição majoritária que o exclui do lugar daquele que sabe sobre sua prática e sobre seu desejo de estar ali como alguém que está aqui há mais tempo.

Poderíamos dizer figurativamente que precisamos de mais poesia na Educação, não no sentido romântico, que foi o motor para essa pesquisa, mas sim no sentido de enigma. A poesia traz em si algo que falta na palavra dos professores, como disse Lacan (1953/1954), a ambiguidade, a possibilidade de significar outras coisas e fazer esse aluno sair do circuito Imaginário que toma conta da contemporaneidade.

Acreditamos que, sob nossas escolhas, conseguimos demonstrar como a Psicanálise pode contribuir para a compreensão da educação, da crise da Educação e da autoridade da palavra do professor diante de tal crise, assim como apresentar uma reflexão acerca do possível esvaziamento da autoridade da palavra do professor na contemporaneidade como provável consequência da crise na Educação.

Realizar uma pesquisa em Psicanálise e Educação com certeza não é das tarefas mais simples e Dunker nos alertou sobre isso: "Escrever uma tese, particularmente quando o tema é Psicanálise, é um desafio ao narcisismo. Se você não se coloca o texto é anódino, se você se coloca o texto te expõe." (DUNKER, 2010) ${ }^{32}$. Essa insegurança sobre o que será 'dito'

\footnotetext{
${ }^{32}$ Sem numeração de páginas.
} 
acompanha a todo aquele que se aventura na escrita. Outra constatação de Dunker, que toca no tema da elaboração, traz a questão intrínseca ao trabalho exaustivo da própria aprendizagem, seja em que nível for e que ressoa em nosso processo de escrita: "Não gaste seus preciosos e escassos recursos em comparações inúteis tentando saber todo o mapa antes de começar. A errância faz parte da viagem” (DUNKER, 2010, p.6). Para finalizar, Batista pôde encontrar um meio de resumir de maneira simples e verdadeira as metáforas desse processo: "Estudar é (des)encontrar-se e aprender não implica apenas "adquirir novos conhecimentos". A questão é que esses conhecimentos (trans)formam o sujeito que aprende." (informação pessoal) ${ }^{33}$

Iniciamos esta dissertação com as palavras de Clarice Lispector que muito nos toca à medida que nos dá a oportunidade de começar as nossas. Por este motivo finalizamos com ela mais uma vez, sobre nossa empreitada na escrita na qual, muitas vezes, nos misturamos entre a pesquisa e nós mesmos e às vezes nos perdemos no vazio:

Tenho medo de escrever. É tão perigoso. Quem tentou, sabe. Perigo de mexer no que está oculto - e o mundo não está à tona, está oculto em suas raízes submersas em profundidades do mar. Para escrever tenho que me colocar no vazio. Neste vazio é que existo intuitivamente. Mas é um vazio terrivelmente perigoso: dele arranco sangue. Sou um escritor que tem medo da cilada das palavras: as palavras que digo escondem outras - quais? talvez as diga. Escrever é uma pedra lançada no poço fundo. Clarice Lispector (1999, p. 15).

Já não tenho mais medo de escrever, me foi jogada a "isca" e creditada a mim a certeza de que minhas palavras têm algo a dizer. Esse é o trabalho do mestre, permitir o enganche do aluno oferecendo a ele a possibilidade de produzir saber, um saber que na verdade é um saber sobre si e que faz movimentar em direção a querer saber mais.

\footnotetext{
${ }^{33}$ Batista, D. E. (Informação pessoal). Mensagem recebida por danieamf17@ yahoo.com.br em 15 de fevereiro de 2014
} 


\section{REFERÊNCIAS BIBLIOGRÁFICAS}

ARANHA, M. L. A. História da Educação. São Paulo: Moderna, 1989.

ARENDT, H. Crise na educação. In: . Entre o passado e o futuro (1968). São Paulo: Perspectiva, 2013.

BARROS, R. R. Prefácio à edição brasileira. In: DUFOUR, D. Cidade Perversa: Liberalismo e pornografia. Rio de janeiro: Civilização Brasileira, 2013.

BATISTA, D. E. O declínio da transmissão na educação: notas psicanalíticas. São Paulo: Annablume/Fapesp, 2012.

BIRMAN, J. Mal-estar na atualidade: a psicanálise e as novas formas de subjetivação. Rio de Janeiro: Civilização Brasileira, 2005.

BLANCHOT, M. Le pas au-delà. França: Galimard, 1973.

BORGES, H. Uma aula de inovação. Revista Veja, São Paulo, Ano 47, n 19 edição 2372. Abril, 2014.

BOTO, C. A escola do homem novo: entre o Iluminismo e a Revolução Francesa. São Paulo: Editora da Universidade Estadual Paulista, 1996.

BOTO, C. Na Revolução Francesa, os princípios democráticos da escola pública, laica e gratuita: o Relatório de Condorcet. Educação e Sociedade, CEDES/Campinas, v. 24, n. 84, p. 735-762, 2003

CALIXTO, F. A. A palavra em Paulo Freire e a palavra em Jacques Lacan. 2007. 254f. Tese (Doutorado em Educação) - Faculdade de Educação, Universidade de São Paulo, São Paulo. 2007

CAMARGO, A. C. C. S. Educar: uma questão metodológica? Proposições psicanalíticas sobre o ensinar e o aprender. Rio de Janeiro: Vozes, 2006.

CARVAlHO, D. Como manter a escola em pé. Revista Supra Ensino, São Paulo, Ano 19, $\mathrm{n}^{\circ} 216.2014$.

CARVALHO, J. S. F. A crise na educação como crise da modernidade. Educação, São Paulo, p. $16-25,2011$.

CARVALHO. J. S. F. Para que ou em nome de quê? Sobre os fins e os meios de por quê irmos à escola. Revista Educação - Coluna Contraponto, São Paulo, ed. 195, Jul. 2013a. Disponível em: <http://revistaeducacao.uol.com.br/textos/195/artigo292325-1.asp>. Acesso em: 07 Mar. 2014. (sem numeração de página)

CARVALHO, J. S. F. Reflexões sobre educação, formação e esfera pública. Porto Alegre: Penso, 2013b. 
CÉSAR, M. R.; DUARTE, A. Hannah Arendt: pensar a crise da educação no mundo contemporâneo. Revista Educação e Pesquisa, São Paulo, v. 36, n.3, p. 823-837, set./dez. 2010 .

CHAVES, C. W. O estatuto do real em Lacan: dos primeiros escritos ao seminário VII, a ética da psicanálise. Revista Paidéia: 16 (34), p. 161-168, Universidade Federal de São João Del Rei, 2006.

COELHO, J. P. Dicionário de literatura. 3. ed. Rio de Janeiro: Cia. José Aguilar Editora, 1973.

DEINA, W. J. A educação na esteira da crise política da modernidade: Uma análise a partir das reflexões de Hannah Arendt. 2012. 213f. Tese (Doutorado em Educação) Faculdade de Educação, Universidade de São Paulo, São Paulo. 2012.

DIAS, S. Resenha: A arte de reduzir as cabeças. Psicologia Revista, São Paulo, n. 15(2), p. 249-253, Nov. 2006. Disponível em:

<http://revistas.pucsp.br/index.php/psicorevista/article/viewFile/18091/13447>. Acesso em: 22 Out. 2014.

DOR, J. Introdução à leitura de Lacan: o inconsciente estruturado como linguagem. Porto Alegre: Artmed, 1989.

DUFOUR, D. Rumo ao capitalismo total? Le monde Diplomatique - Brasil. 2001 Disponível em: <http://www.diplomatique.org.br/acervo.php?id=301․ Acesso em: 29 Fev. 2015

A arte de reduzir as cabeças: sobre a nova servidão na sociedade ultraliberal. Rio de Janeiro: Companhia de Freud, 2005a.

O homem neoliberal: da redução das cabeças à mudança dos corpos. Le monde Diplomatique - Brasil. 01 Abr. 2005b. Disponível em: <http://www.diplomatique.org.br/acervo.php?id=1301\&tipo=acervo.>_Acesso em: 05 Dez. 2014.

DUNKER, Christian. Os 27+1 erros mais comuns de quem quer escrever uma tese em psicanálise. Revista da associação psicanalítica de Curitiba, Curitiba, v. 20, 2010.

DURKHEIM, E. A Educação - sua natureza e função. In: Educação e Sociologia. São Paulo: Melhoramentos, 1978.

ELIA, L. A Transferência na Pesquisa em Psicanálise: Lugar ou Excesso? Psicologia Reflexão e Crítica, Porto Alegre, v. 12, n. 3, 1999. Disponível em: <http://dx.doi.org/10.1590/S0102-79721999000300015>. Acesso em 20 dez. 2014. (sem paginação)

FREUD, S. Totem e Tabu e outros trabalhos. Trad. Sob direção de Jayme Salomão (Edição Standard Brasileira das Obras Psicológicas Completas de Sigmund Freud). Rio de Janeiro: Imago, 1969. 
O mal-estar na civilização. Trad. Sob direção de Jayme Salomão (Edição Standard Brasileira das Obras Psicológicas Completas de Sigmund Freud). Rio de Janeiro: Imago, 1996 KUPFER, M.C. M. Por uma vara de vidoeiro simbólica. In: Aquino, J.G. Autoridade e autonomia na escola: alternativas teóricas e práticas.São Paulo: Summus, 1999

Educação para o futuro: psicanálise e educação. 3 ed. São Paulo: Escuta, 2007a.

Freud e a educação: o mestre do impossível. São Paulo: Scipione, 2007b.

GARCIA-ROZA, L. A. Palavra e Verdade. Rio de Janeiro: Jorge Zahar, 1998.

LACAN, J. O seminário, livro 17: o avesso da Psicanálise. Rio de Janeiro: Jorge Zahar, 1992. 1998a.

Função e campo da fala e da linguagem. In: Escritos. Rio de Janeiro: Zahar,

O estádio do espelho como formador da função do eu. In:

Escritos. Rio de Janeiro, Zahar, 1998b.

A coisa freudiana ou Sentido do retorno a Freud em psicanálise. In: Escritos. Rio de Janeiro, Zahar, 1998c.

A função criativa da palavra. In:

O Seminário: Livro I: os escritos técnicos de Freud. Rio de Janeiro: Jorge Zahar, 1953-1954.

LAJONQUIÈRE, L. Infância e ilusão (psico)pedagógica: escritos de psicanálise e educação. Rio de Janeiro: Vozes, 1999.

Psicanálise, modernidade e fraternidade. In KHEL, M. R. (org.). Função Fraterna. Rio de janeiro: Relume Dumara, 2000.

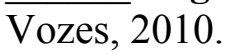

Figuras do infantil: a psicanálise na vida cotidiana com as crianças. Rio de Janeiro:

. A mestria da palavra: isso duro de roer na formação de professores. In: MRECH, L.M.; PEREIRA, M.R. Psicanálise, transmissão e formação de professores. Minas Gerais: Fino Traço/FAPEMIG, 2011

Introdução. In: BATISTA, D. O declínio da transmissão na educação: notas psicanalíticas. São Paulo: Annablume; Fapesp, 2012.

LAPLANCHE; PONTALIS. Dicionário de Psicanálise. 4. ed. São Paulo: Martins Fontes, 2001.

LEBRUN, J. P. Um mundo sem limite: ensaio para uma clínica psicanalítica do social. Rio de Janeiro : Companhia de Freud, 2004. 
LISPECTOR, C. Um sopro de vida. Rio de Janeiro: Rocco, 1999

MELMAN, C. O homem sem gravidade: gozar a qualquer preço. Rio de Janeiro: Companhia de Freud, 2008.

MOÇO, A. Como se resolve a indisciplina? Conquistar autoridade com o conhecimento e o respeito do aluno. Revista Nova Escola, ediçao 226, Out. 2009. Disponível em: $<$ http://revistaescola.abril.com.br/formacao/formacao-continuada/como-resolve-indisciplinaautoridade-moral-convencao-cooperacao-autonomia-503230.shtml?page $=3>$. Acesso em: 05 Mar. 2015.

MRECH, L. M. Psicanálise e Educação: novos operadores de leitura. São Paulo: Pioneira Thomson Learning, 2003.

(org.). O impacto da psicanálise na educação. São Paulo: Editora Avecamp, 2005. 2008. Lacan, a Educação e o Impossível de Educar. Educação, São Paulo, v. 9, p. 16-27,

MOISÉS, M. Dicionário de termos literários. São Paulo: Cultrix, 1986.

MOSER, I. R. F. A crise da autoridade na educação: O discurso e a imagem docente reformulada. 2012. 130f. Dissertação (Mestrado em Educação) Faculdade de Educação, Universidade de São Paulo, São Paulo, 2012.

MILLOT, C. Totem e Tabu. In: Freud antipedagogo. Rio de Janeiro: Jorge Zahar, 2001.

NEILL, A. S. Liberdade sem medo - Summerhill: radical transformação na teoria e na prática da educação. São Paulo: IBRASA, 1980.

PEREIRA, M. R. O impacto do discurso da ciência na relação professor-aluno: repercussões em psicanálise. Revista Estilos da clínica/Instituto de Psicologia, Universidade de São Paulo.Vol.XIII, n24, 210-223, 2008. 32, 2009.

A autoridade docente interrogada. Revista Extra-Classe, Ouro Preto, v.1, n.2, p.15 - 
A ética em Riobaldo: ensino, modernidade e psicanálise. In: MRECH, L.M.; PEREIRA, M.R. Psicanálise, transmissão e formação de professores. Minas Gerais: Fino Traço/FAPEMIG, 2011.

RATIER, R. Fala que eu não te escuto: Desvalorização profissional, competidores de outras áreas e normas inconstitucionais calam o professor no debate educacional. Revista Nova Escola, São Paulo, n.280, ano 30, p.10-11, 2015.

SZAPIRO, A. M. Em tempos de Pós-modernidade: Vivendo a Vida Saudável e Sem Paixões. Revista Estudos e Pesquisas em Psicologia, UERJ, Rio de Janeiro, R.J., ano 5, n.1, $1^{\circ}$ semestre de 2005. Disponível em: <http://www.revispsi.uerj.br/v5n1/artigos/a02.pdf>. Acesso em: 15 Fev.2015.

TOURAINE, A. Poderemos viver juntos? Iguais e diferentes. Rio de Janeiro: Vozes, 1998.

VOLTOLINI, R. Educação e psicanálise. Rio de Janeiro: Zahar, 2011.

, R. Ementa do $9^{\circ}$ Colóquio Internacional do LEPSI / $4^{\circ}$ RUEPSY | Retratos do malestar contemporâneo na educação (18/10/2012 - 20/10/2012). Disponível em: <http://www3.fe.usp.br/secoes/inst/novo/eventos/detalhado.asp?num=803>. Acesso em: 16 Set. 2012. 


\section{APÊNDICE}

\section{ENTREVISTAS TRANSCRITAS NA ÍNTEGRA}

\section{Carla -Professora do Ensino Fundamental I e II}

$\mathrm{P}$ - Sua idade?

$\mathrm{R}$ - Trinta e três anos.

$\mathrm{P}$ - Local onde você nasceu?

R - São Paulo.

$\mathrm{P}$ - Local onde viveu a maior parte?

R - São Paulo.

$\mathrm{P}$ - Formação?

$\mathrm{R}$ - Pedagoga.

$\mathrm{P}$ - Há quanto tempo é professora?

$\mathrm{R}$ - Onze anos.

$\mathrm{P}$ - Como era, na sua família, a abertura para falar e conversar?

$\mathrm{R}$ - Era tranquilo, apesar da minha mãe não ter muito tempo, a gente conseguia conversar sim, entre família. O meu pai era mais acessível, a minha mãe sempre vivia mais ocupada.

$\mathrm{P}$ - E qual o espaço que as crianças tinham para falar?

$\mathrm{R}$ - A gente tinha bastante espaço. É como eu falei, com a minha mãe era mais difícil, porque ela tinha pouco tempo, a gente tinha mais medo dela, mas com o meu pai sempre a conversa foi muito acessível, a gente conversava bastante.

$\mathrm{P}$ - Como era tratada a autoridade dos adultos sobre as crianças na sua infância?

$\mathrm{R}$ - Os adultos tinham autoridade máxima, então... aliás, não precisavam nem falar, né, às vezes, só olhar, minha mãe principalmente, só de olhar, a gente já sabia o que podia, o que que não podia. Às vezes, era até ruim, porque a gente ficava com medo de pedir algumas coisas, né, por conta da resposta, mas era... a autoridade era respeitada, os pais eram autoridade máxima em casa. 
P - Agora sobre a prática pedagógica. Se você comparar as suas ações, sua rotina de sala de aula com a de muitos anos atrás, você percebe alguma mudança da relação dos alunos com a sua palavra?

$\mathrm{R}-\mathrm{Sim}$

$\mathrm{P}-$ Quais seriam?

$\mathrm{R}$ - Eu tô há onze anos como professora, exerço a profissão e mudou muito...

$\mathrm{P}$ - Na mesma escola?

R - Não. Escolas diferentes, mas mudou muito. Essa escola, por exemplo, aqui, eu tô há cinco anos e a gente consegue perceber que tá drástico assim, eles não têm mais... essa questão de autoridade para eles, não existe e eu sempre acho que como em casa, eles não têm isso, então, na escola é muito difícil eles entenderem que o professor é uma autoridade, exerce uma autoridade que eles têm que escutar. Então, eles questionam o tempo todo, mas não é um questionamento sadio, é questionar ações, se você pede para sentar, já é motivo para questionar, eles não querem, porque eles acham que ninguém manda neles, então: "não preciso sentar, porque você não manda em mim", então é muito complicada essa questão da conversa com eles, porque eles acham que você tá afrontando eles o tempo todo. Qualquer pedido se torna uma afronta, ai uma afronta se torna uma briga, um conflito e ai, resolver conflito é muito mais complicado, mais difícil.

P - Quando você está ministrando aulas, quais são as suas maiores preocupações com o quê e quem está falando?

$\mathrm{R}$ - Repete pra mim, por favor, que eu não entendi a...

P - Quando você tá dá dando aula, quais são as suas maiores preocupações com o que você tá falando, ou com quem você tá falando?

$\mathrm{R}$ - É que nesse momento, eu tô na sala de informática, no laboratório de informática, então a fala é diferente, porque eu lido com eles desde o primeiro ano até o nono ano. Então, a minha preocupação nesse momento é a faixa etária, então com o primeiro ano até o terceiro ano vai ser diferente, porque eles escutam mais, então a tática vai ser diferente.

$\mathrm{P}$ - Os menores? 
$\mathrm{R}$ - Os menores escutam mais. Agora, a partir do quarto ano já começa a modificar, então, por exemplo, a minha tática... eles sabem que eu não falo enquanto eles não... eles não escutam, então eu fico esperando, com a boca fechada, esperando por eles até o momento de eu falar e é isso que eu tenho conseguido fazer, ai quando eles se acalmam, eu falo. Então, o escutar para eles é bem difícil, é bem complicado.

$\mathrm{P}$ - Até que ponto você considera que seus alunos te escutam? Em quais ocasiões e em que outras isso não acontece?

$\mathrm{R}$ - Essa pergunta é complicada, é como eu falei, até o terceiro ano essa questão do escutar é muito mais fácil. Aqui na escola, a gente tem uma ruptura que é assim, o quinto ano é muito fácil de trabalhar, o quarto ano já é muito difícil por uma série de circunstâncias. Então, eles não escutam, isso é básico, eles não escutam. Sétimo, oitavo e nono que são as fases finais também, a questão do escutar é muito complicado. É muito complicada, então a sensação mesmo é de que eles não escutam nada do que você fala, tanto que você acaba de explicar a atividade, pede para eles fazerem, eles falam que não entenderam, que você não explicou. Você acabou de explicar e não entenderam.

$\mathrm{P}$ - O que você nomearia como a maior dificuldade de um professor de Ensino Fundamental, hoje?

$\mathrm{R}-\mathrm{A}$ indisciplina.

$\mathrm{P}-\mathrm{A}$ indisciplina?

$\mathrm{R}$ - É. A indisciplina é a maior dificuldade. A falta de respeito, de compromisso, de comprometimento, eles não... para eles, parece que a educação não tem valor nenhum. Então, eles não entendem o porquê da educação, o porquê de estar na escola, eles acham que eles vêm porque são obrigados pelos pais e só por isso que eles vêm. Então, eles não têm comprometimento nenhum.

$\mathrm{P}$ - De que maneira você acha que os alunos veem você?

$\mathrm{R}$ - Como eu tô no laboratório de informática, é ainda uma matéria que eles gostam, pelo fator de ter um computador e ser aula diferente. Mas isso, também, é até o quinto ano, porque a partir do sexto, sétimo, oitavo, eles têm um celular que tem muito mais tecnologia do que eu tenho dentro da sala de aula. Então, pra chamar a atenção deles é muito mais difícil, que a minha tecnologia é obsoleta para eles, né, o celular deles faz muito mais coisa do que o 
computador da escola faz. Então, a briga com os maiores é com a tecnologia. Com os menores, você ainda consegue chamar a atenção, mas como eu tô no laboratório, né, como a minha aula é diferente, então eles conseguem ver como sendo uma aula diferente. Então, os pequenos, principalmente, eles têm muito isso, ficam ansiosos com a aula. Me vêm no corredor, ficam perguntando toda hora quando vai ter aula, é uma vez só por semana, então isso faz com que se torne um diferencial. Então, eles têm uma expectativa com relação a essa aula, por ser diferente.

$\mathrm{P}-\mathrm{E}$ o quê que você dá na sua aula para os maiores?

$\mathrm{R}$ - Para os maiores, eu sigo os temas que são trabalhados com eles em sala, então por exemplo, o nono ano, eles estão trabalhando com a questão do bairro, então eu sigo essa temática, do bairro, das mudanças do bairro, com pesquisa, com gráfico, então eu vou usar o que tem de tecnologia no computador pra eles aprofundarem na pesquisa. Com os oitavos, também é bairro. Sétimo ano, a gente tá trabalhando com a questão da água; quinto, cidadania. Então, a gente vai seguindo as temáticas que os professores estão trabalhando, só que usa tecnologia pra abordar esses temas.

$\mathrm{P}$ - Tem mais alguma coisa que você quer falar?

R - Não, obrigada.

$\mathrm{P}$ - Obrigada.

$\mathrm{R}$ - Nada.

\section{Bruno -Professor do Ensino Fundamental II}

$\mathrm{P}$ - Sua idade?

$\mathrm{R}$ - Quarenta e oito.

$\mathrm{P}$ - Local onde você nasceu?

R - São Paulo.

$\mathrm{P}-\mathrm{E}$ onde você viveu a maior parte?

R - São Paulo. 
$\mathrm{P}$ - Sua formação?

$\mathrm{R}$ - Eu sou formado em Ciências, Biologia.

$\mathrm{P}-\mathrm{E}$ há quanto tempo você é professor?

R - Há exatamente 21 anos.

$\mathrm{P}$ - Como que era na sua família, a abertura para falar e conversar?

$\mathrm{R}$ - Sobre que assunto?

$\mathrm{P}$ - Qualquer assunto.

$\mathrm{R}$ - Total, sempre teve abertura, sempre teve.

$\mathrm{P}$ - E o espaço que as crianças tinham para falar?

$\mathrm{R}$ - Não vou dizer que seja o mesmo do adulto, que tem assunto que adulto não vai discutir com criança, mas aquilo que fosse pertinente à idade, sempre tivemos.

P - Legal. Como que era tratada a autoridade dos adultos sobre as crianças na sua infância?

$\mathrm{R}$ - Eu acho que primeiro, ensinar princípios, né, e em cima disso daí, as crianças tinham que seguir esses princípios, né, que são princípios, acho que conversar essa questão do respeito, a questão do cumprimento de horários, das coisas, vai fazer as atividades, tudo o que tinha que ser feito. Ninguém nunca precisou me cobrar, eu sempre fui uma pessoa que procurava fazer a minha parte.

P - Legal. Agora, vou fazer umas perguntas da sua prática mesmo. Se você comparar as suas ações, sua rotina de sala de aula com a de muitos anos atrás, você percebe alguma mudança na reação dos alunos com a sua palavra? Quais seriam elas?

$\mathrm{R}$ - Olha, eu sempre, desde o início, quando eu comecei a dar aula, eu sempre procurei dar um tipo de aula que eu gostaria de ter tido, né? E assim, com algumas exceções, eu sempre tive um bom relacionamento com os alunos, nunca tive problemas graves. Eu sempre procurei ter uma relação amigável com eles, de respeito, obviamente, mas procurando levar para eles a importância do conhecimento da vida deles. Então, a partir do momento que a pessoa vê porque que ele tá aprendendo determinados conteúdos, ele passa a valorizar o estudo, né? Logicamente, que a gente não consegue isso aí com todos, mas com uma boa parcela. 
$\mathrm{P}$ - E quando você, professor tá ministrando aula, quais são as suas maiores preocupações com o que você tá falando e com quem você tá falando?

$\mathrm{R}$ - Primeira preocupação minha é levar temas que são relevantes para os alunos, que tenham alguma utilidade na vida deles, lógico que existe o currículo, mas em cima disso daí, a gente procura despertar no aluno assim, eu sempre quando entro no assunto, eu procuro ver, mostrar para o aluno porque que ele tá aprendendo aquele conteúdo e aí, quando eu percebo que os alunos perceberam a importância que tem na vida deles é que ai, a aula, ela transcorre mais naturalmente, melhor.

P - Até que ponto você considera que seus alunos te escutam, em que ocasiões? E em que outras isso não acontece?

$\mathrm{R}$ - Você tem assim, de uma forma geral, eles escutam, mas você tem aqueles alunos que são... que já vêm pra escola sem a intenção de querer aprender. Então, eles acabam atrapalhando e nisso daí, muitas vezes, você se vê na seguinte situação: ou você tenta fazer com que o aluno mude de postura ou você vê que não conseguiu de forma alguma, aí infelizmente, você tem que tomar outras atitudes, tá, a última delas é tirá-lo da sala, tentar ainda conversar com ele fora da sala, se você vê que não teve jeito mesmo, chamar a direção ou a coordenação para tentar intermediar a relação professor-aluno. Mas são pouquíssimos alunos que dão esse tipo de problema.

$\mathrm{P}$ - Nunca tem uma situação em que você acha que todos se dispersam?

R - Não.

$\mathrm{P}-\mathrm{Não}$ ?

R - Não.

$\mathrm{P}$ - O que você nomearia como a maior dificuldade do professor do Ensino Fundamental, hoje?

$\mathrm{R}$ - Maior dificuldade?

$P-E ́$.

$\mathrm{R}$ - Primeiro, mudar a imagem perante alunos e pais de alunos que a escola pública, ela não oferece boa qualidade. Primeira coisa. Isso aí foi um trabalho feito durante muitos anos 
denegrindo a imagem da escola pública, porque se a gente for analisar, o currículo é o mesmo, se o currículo é o mesmo, onde que tá a diferença entre a pública e a particular? E aí, a gente procura passar para os alunos que o diferencial, na verdade, são eles, que quem faz a escola é o aluno, que ele tem que procurar ter uma postura diferente do que a maioria tem e que é o futuro dele que tá em jogo. Não é que ter um diploma vai garantir, mas o conhecimento, ele ainda garante uma qualidade de vida melhor, em termos profissionais, do que o que não tem conhecimento nenhum.

$\mathrm{P}$ - Você acha que eles te escutam nesse aspecto?

$\mathrm{R}$ - Eu acredito que sim, porque como eu falei, não todos, mas assim, uma boa parcela escuta. Agora, o difícil é você em pouco tempo na escola, tentar convencer o aluno e ter todo um aparato externo que diz o contrário. Então assim, hoje, o adolescente que seria, vamos dizer assim, a geração Z, né, que eles falam, ele tem outras preocupações, outros interesses. Então, aquele aluno, que ele faz um monte de coisa ao mesmo tempo, não aprofunda em nada. Então, é muito difícil você conseguir fazer um aluno focar no assunto e entrar naquele assunto e realmente, aprender aquilo. Então assim, é um convencimento que você fala ao longo de dois anos, três anos. Às vezes, o que acontece? Você começa a trabalhar o aluno, quando começa a entrar nesse esquema de pensamento, e você já muda de turma e você já não tem mais contato com aquele aluno. E se esse trabalho não for dado em continuidade, você perdeu.

$\mathrm{P}$ - Legal. De que maneira você acha que os alunos veem você?

$\mathrm{R}$ - Eu acho que uma pessoa que procura facilitar o aprendizado deles, procura manter o melhor relacionamento possível, com um certo ponto de amizade, alguns alunos já procuram a ter amizade, só que assim, aluno é aluno; professor é professor, né? Tranquilo, não são problemas de violência ou de desrespeito, assim, como eu procuro respeitá-lo, de um modo geral, eles também me respeitam.

$\mathrm{P}$ - Legal. Tem mais alguma coisa que você quer falar?

$\mathrm{R}$ - Bom, eu penso assim que com relação à escola, que enquanto não houver um investimento verdadeiro onde deva acontecer o ensino do modo geral - não estou falando só ensino público, mas ensino particular também, que a diferença em termos de resultado, não são discrepantes - se não houver um investimento sério, pelo menos na escola pública, nós nunca vamos atingir um patamar de excelência. E não é apenas com promessas do Pré-Sal que vai investir $10 \%$ em educação, que na Europa, os três países que acabaram quebrando foram 
Portugal, Espanha e Grécia, eles investiam 15 e quebraram. A Alemanha não quebrou, porque investiu mais em educação. Então assim, achar que $10 \%$ do PIB vai resolver o problema e achar que o professor vai resolver tudo é utopia.

$\mathrm{P}$ - E esse investimento que você tá falando é investimento em quê? Professor, infraestrutura? $\mathrm{R}$ - Investimento em formação, mas não formação tópica, por exemplo, universidade aberta, você oferece seis vagas, tem uma rede com não sei quantos mil professores, ridículo, você vai ter meia-dúzia e o resto não vai ter acesso. E assim, a dificuldade que existe hoje, professor aparecer, porque quando um professor, por exemplo, vai à rua e faz uma greve, por exemplo, para reivindicar melhores condições de trabalho, salário, etc., isso quase não é divulgado. Você vê uma passeata de 100 pessoas na rua, a mídia dá toda uma atenção e da educação, não. Quando eles vão mostrar alguma coisa, que é muito pouco, é porque a coisa já tá estourando, não tem mais como esconder. Então, nós chegamos, por exemplo, a ter uma greve com 15 mil professores descendo a Consolação e eles colocavam que tinham 3 mil, nunca que 3 mil pessoas vão encher a Consolação, é fisicamente impossível, não tem nem como eles darem essa desculpa e assim, infelizmente, e por isso que algumas pessoas dizem que não é gastando mais com educação que ela vai melhorar, porque tem países pobres que têm resultados melhores. Só que o Brasil é um dos países que menos investe em educação, então assim, como que o resultado é pior? A Alemanha hoje tem analfabetos, mas eles têm outras exigências lá, o nível de exigência é muito maior do que aqui, então não dá para comparar, sabe, falar que lá tá pior que aqui ou tá igual, é mentira, não tá, mas a mídia procura colocar. E assim, outra coisa é aumentar as atribuições do professor além do que ele tem que fazer: "Nós precisamos discutir tal assunto", a escola tem que colocar, "surgiu um novo assunto", a escola que tem que colocar, tudo é a escola e isso vai sobrecarregando o professor e aí, o resultado que deveria ter que é uma melhora não acontece, tá sendo sobrecarregado o professor hoje. Na prefeitura de São Paulo, a nota hoje, teoricamente, reprova, não é que vai ser o único componente, mas todo o mecanismo e aparato hoje continua sendo assim: "Olha, podemos reprovar, mas no máximo, tanto" "E o resto?" "Vai ter que passar", pô, quer dizer, vou ter que passar em que condições? Analfabeto, vai ter que ser promovido, porque a idade dele já ultrapassou, vai ter que ser promovido porque não vão querer ver a cara dele na escola e "Se isso não acontecer?" "Bom, a sua avaliação vai diminuir, você vai receber a supervisão da escola", você vai receber toda a pressão para promover, ou simplesmente, o diretor vai lá, assina, ou o supervisor e tá promovido, atropelando todo o trabalho pedagógico que a escola fez. Isso daí eu já vi muito em várias escolas. É isso. 


\section{Ricardo -Professor do Ensino Fundamental II - Ciências}

$\mathrm{P}$ - Sua idade?

$\mathrm{R}$ - Eu tenho 34 anos.

$\mathrm{P}$ - Local onde você nasceu?

$\mathrm{R}$ - Aqui em São Paulo, mesmo.

$\mathrm{P}-\mathrm{E}$ onde você viveu a maior parte?

R - Você fala o bairro? É São Paulo, mesmo.

$\mathrm{P}$ - Formação?

$\mathrm{R}$ - Minha formação é Licenciatura em Ciências, Educação Ambiental.

$\mathrm{P}$ - Há quanto tempo você é professor?

$\mathrm{R}-$ Quatro anos.

$\mathrm{P}$ - Como que era na sua família, a abertura para falar e para conversar?

$\mathrm{R}$ - Nossa família sempre encontrou momentos, até se reunir, não necessariamente na hora das refeições, mas sempre no final do dia, acho que o diálogo era bem aberto em casa.

$\mathrm{P}$ - Qual que era o espaço que as crianças tinham para falar?

$\mathrm{R}$ - Todo momento, a gente tava sendo questionado, né, então sempre queriam saber um pouco da nossa vida, do nosso dia, e a gente acabava... eu e a minha irmã, a gente acabava até que se posicionando em algumas coisas, né, geralmente, meus pais, nesse sentido, eles deram muita voz pra gente, muita abertura, por isso foi acho que foi uma infância tranquila.

$\mathrm{P}$ - Como que era tratada a autoridade dos adultos sobre as crianças na sua infância?

$\mathrm{R}$ - Eu acho que a relação era muito mais de autoritarismo do que autoridade nas relações escolares. Na família, não. Na família, meus pais levavam de forma mais tranquila assim, sempre com diálogo, sempre que eles sempre falam orgulhosos para os outros: "Nunca bati nos meus filhos, eles nunca me deram problemas", falando com os vizinhos, essas coisas. 
$\mathrm{P}$ - E na escola?

$\mathrm{R}$ - Na escola, a relação era mais autoritária, uma coisa meio mecânica. Mas eu tinha, eu lembro de bons professores, assim, professores que estimulavam o questionamento, estimulavam o rompimento da ordem estabelecida na escola. Eu tenho boas lembranças assim.

P - Legal. Agora, eu vou perguntar um pouco sobre a sua prática. Se você comparar suas ações, sua rotina em sala de aula com a de muitos anos atrás, você percebe alguma mudança da relação dos alunos com a sua palavra?

$\mathrm{R}$ - Eu comparo a minha prática nesses quatro anos, o que aconteceu? Os três primeiros anos, eu trabalhei numa outra escola, com uma situação bem diferente dessa, acho que essa mudança de escola me proporcionou olhar um outro projeto, vivenciar um outro projeto...

$\mathrm{P}$ - Era escola pública também?

$\mathrm{R}$ - Era pública também, ficava no bairro do Rio Pequeno, aqui na zona Oeste também, mas com uma realidade bem diferente. Alunos com um comportamento muito mais agressivos, a arquitetura da escola era diferente, era bem opressora mesmo, parecia uma prisão. Aqui, eu vejo uma escola bonita, limpa, cuidada, porque está dentro de uma estrutura maior que é o CÉU. Acho que isso acaba ajudando. Nesse sentido, na minha avaliação, essa mudança foi bem positiva, embora não tenha aulas atribuídas a mim, não sou regente, então a gente entra substituindo, então é sempre uma surpresa. Isso mudou também na minha vida, porque eu tinha todo o meu programa, as salas eram atribuídas a mim, já nessa escola, não. Então, a gente é sempre pego de surpresa.

P - E quando você, professor, tá ministrando aula, quais são as suas maiores preocupações com o que e com quem você tá falando?

$\mathrm{R}$ - Eu me preocupo se o que eu tô falando tem embasamento, me preocupo se eu tô me fazendo entender, me preocupo com quem tô falando, preciso da atenção, né, que eles estejam envolvidos, de certa forma, que perguntem, que tirem dúvidas, acho que é essa a minha preocupação.

$\mathrm{P}$ - Até que ponto você considera que os seus alunos te escutam em quais ocasiões e em que outras, isso não acontece?

$\mathrm{R}$ - Eu vejo que eles estão me escutando quando eles passam a questionar alguma coisa que eu falei, então, eles pensaram, sintetizaram a informação, trabalharam com ela e aí, 
encontraram algum ponto de talvez incoerência, ou talvez que eles não entenderam bem, então, a gente quando é questionado, sabe que eles estão prestando atenção. Agora, eu vejo quando eles não estão prestando atenção quando eles estão conversando, distraídos, com fone, dando as costas, saindo, fogem da sala. Acho que as questões... quando eles promovem indisciplina dentro da sala, você vê que eles estão bagunçando ou fazendo qualquer outra coisa que não...

$\mathrm{P}$ - E o quê que acontece mais? Um ou outro? Ou os dois?

$\mathrm{R}$ - Acho que os dois, sei lá, a gente sempre tem mania de olhar o copo meio vazio, não é? Tem alguns alunos indisciplinados na sala, toda sala de aula vai ter, mas eu senti essa diferença aqui. Aqui, eles costumam prestar mais atenção no que acontece, nas atividades propostas, costumam se empenhar mais do que na outra escola, na outra escola era mais complicado isso.

$\mathrm{P}$ - O que você nomearia como a maior dificuldade do professor do Ensino Fundamental, hoje?

$\mathrm{R}$ - A maior dificuldade é estrutura da Rede Municipal... não só da rede Municipal, da Rede de Educação do país, acho que a gente tem muitos problemas estruturais. No âmbito da escola, as relações entre professores, a relação entre professor-gestor é mais complicado do que relação professor-aluno. Eu acho que a gente tem muitos mais problemas aí e também com questões burocráticas da própria escola que toma um tempo que poderia ser mais dedicado a planejamento de aulas, discussão da prática, que isso, a gente tem muito pouco tempo pra organizar as nossas atividades e pensá-las também, não só organizá-las, mas pensálas. Acho que é isso.

$\mathrm{P}$ - De que maneira você acha que os alunos veem você?

$\mathrm{R}$ - No geral, eles gostam, me respeitam, mas eu acho que eles me veem como uma pessoa mais próxima, que escuta eles. Acho que eles me veem assim na escola, eu nunca tive problemas, nunca fui agredido, nem na outra escola que era mais violenta.

$\mathrm{P}$ - Você conversa bastante com eles?

$\mathrm{R}$ - Converso. Gosto de conversar até coisas fora do assunto da aula, eles falam um pouco... eles querem saber da minha vida, eu falo da vida deles e acho que isso a gente tá aprendendo também, ali, eu tô expondo a minha visão de mundo e eles estão me trazendo a deles. Então, 
tô tanto aprendendo quanto ensinando. É legal aprender um pouco do universo deles, porque a gente sempre se compara com... na nossa época de escola, a coisa era diferente... mas hoje, a gente tem que ter esse entendimento, né, que o mundo é outro hoje do que foi ontem, são outros jovens e eu tô em outro lugar, isso me ajuda a compreender mais a realidade deles, essas conversas informais, conversas de corredor.

$\mathrm{P}$ - Legal. Quer falar mais alguma coisa?

$\mathrm{R}$ - Não, acho que tá bom

$\mathrm{P}$ - Obrigada.

$\mathrm{R}$ - Não sei se foi bom...

P - Perfeito. Ótimo.

\section{Victória - Professora do Ensino Fundamental II - História}

$\mathrm{P}$ - Sua idade?

$\mathrm{R}-$ Eu tenho 38 .

$\mathrm{P}$ - Local onde você nasceu?

$\mathrm{R}$ - Eu nasci no interior de São Paulo, numa cidade chamada Assis.

$\mathrm{P}-$ Assis

$\mathrm{R}-$ Conhece?

$\mathrm{P}$ - Conheço. Formação?

$\mathrm{R}$ - Eu sou formada em História pela UNESP e na própria Assis, eu fiz um curso de... eu tentei fazer a pós-graduação, eu fiz aluno ouvinte especial durante seis meses, mas aí, eu tinha acabado de ter a minha filha, e aí, minha prioridade naquele momento era esse.

$\mathrm{P}$ - Onde você viveu a maior parte da sua vida?

$\mathrm{R}$ - Isso é complexo, porque meus pais são separados, então, eu sou meio itinerante, um pouco cigana. Eu não sei dizer onde eu vivi a maior parte da minha vida. Um pouco lá, um pouco cá. 
$\mathrm{P}$ - Um pouco Assis e um pouco em São Paulo?

$\mathrm{R}-\mathrm{E}$.

$\mathrm{P}$ - Há quanto tempo você é professora?

$\mathrm{R}$ - Doze anos. Treze, na verdade.

$\mathrm{P}$ - Como que era na sua família, a abertura para falar e conversar?

$\mathrm{R}$ - Então, como eu sou filha de pais separados, eu convivi com várias famílias, vários outros familiares. Então, minha... dentro desses vários núcleos que eu participei, tios, avós, pai ou mãe, eu sempre tive liberdade para conversar, pra questionar e me expressar também.

$\mathrm{P}$ - Qual que era o espaço que as crianças tinham para falar?

$\mathrm{R}$ - Dentro da minha família?

$\mathrm{P}-\mathrm{Sim}$.

$\mathrm{R}$ - Sempre foi muito aberto, dentro do limite viável, né, permissível, adequado, nada como... a gente vivia numa outra época, né, tinha toda aquela questão de... da autoridade, ela já tava implícita e explícita, também, então a gente sabia até quando podia. E até a própria questão da criança era uma condição diferente, né? Eu não sei quantos anos você tem, mas...

$\mathrm{P}$ - Vinte e oito.

$\mathrm{R}$ - Já tem uma distância, mas assim, do que eu percebo do que a gente fala com outros professores, até o meu marido que também é professor, era uma coisa que já tava posta, né, a criança, ela não tinha muito essa questão de "Eu não vou fazer" ou "Eu vou fazer porque eu quero", é o que era determinado e... não sei se isso era muito democrático, mas funcionou, né?

P - Como era tratada a autoridade dos adultos sobre as crianças na sua infância? Que é um pouco o que você tá falando.

$\mathrm{R}$ - Então, era uma coisa que era posta, né, e não era questionada. Era uma coisa normal pra gente, do meu entendimento, né, eu sabia que no caso, essa figura de pai e mãe não era uma coisa muito clara pra mim, no sentido de que eu fui criada com outros familiares, mas eu sabia que aquela pessoa, ou tio, ou vó, no caso, pai e mãe era o responsável e eu tinha que... 
$\mathrm{P}$ - Por ser mais velha, será?

$\mathrm{R}$ - Não só pelo fato de ser mais velha, era aquele sentimento mesmo de que é alguém - é um pouco ambíguo isso que eu vou falar - mas é alguém que estava cuidando de mim que eu sabia que ele queria o meu bem e por conta disso eu tinha que ouvir, obedecer o que ele queria para que tudo corresse bem.

P - Agora, na prática pedagógica. Se você comparar suas ações, sua rotina de sala de aula com a de muitos anos atrás, você percebe alguma mudança da relação dos alunos com a sua palavra?

$\mathrm{R}$ - Absoluta. Total, completa...

$\mathrm{P}-$ Quais?

$\mathrm{R}-$ Qual?

$\mathrm{P}$ - Você sempre deu aula?

$\mathrm{R}$ - Desde que eu me formei, sim. Eu fiquei... assim, não continuamente, né, intermitente, mas sempre dei aula. A grande mudança é exatamente no ouvir o que o professor tem a dizer. Eles não ouvem, né, eles não permitem ou se permitem... o que existe hoje é essa questão de que o aluno busca. Do meu entendimento, assim, a gente vive numa situação em que o aluno, ele quer o prazer constante. Então, ele quer uma situação em que ele seja sempre permeado de satisfação plena. Então, nada que tire ele dessa zona de conforto, de felicidade, de satisfação vai chamar a atenção dele ou vai fazer com que ele preste atenção, pelo menos ele respeite a situação. Então, por exemplo, se ele... se você traz uma atividade diferenciada, naquele dia, ele tá num bom astral, assim, ele acordou bem, a lua, os astros, a conjuntura, o sol, tudo deu certo, então, ele vai prestar atenção na sua aula, ele vai permitir que você explique, que você dê a sua aula. Então, do que eu vivia na sala de aula, não era exatamente isso, claro que a gente fazia, né, como todo adolescente tinha a bagunça sim, tinha a conversa sim, mas eu, pelo menos, não fui uma aluna brilhante, mas também não era uma aluna medíocre. Tinha o entendimento de que aquilo ali era alguma coisa necessária, era preciso ouvir o que o professor tinha a dizer e que, principalmente, tinha uma consequência de não participar, de não fazer, de não permitir que a aula fosse... aliás, nem existia isso, o não permitir que a aula fosse dada, né? Hoje, eles têm o controle da situação. Eles determinam o que o professor vai 
fazer, o que o professor vai falar, a hora que o professor vai falar, é bastante complicado. Primeiro você tem que conquistar o aluno, para depois você conseguir fazer alguma coisa.

P - Perfeito. Quando você, professora, tá ministrando aula, quais são as suas maiores preocupações com o que e com quem você tá falando?

$\mathrm{R}$ - Eu... a minha maior preocupação é poder transmitir o conteúdo para eles, fazer com que eles consigam assimilar e entender o que eu tô falando e principalmente, construir neles, um espirito crítico deles entenderem, porque História é uma matéria muito difícil, é muito subjetivo para eles, né, não é uma coisa concreta, não é uma coisa que tá falando exatamente do que o que o cara vive. Você construir essa ponte entre o que ele está vivendo, o que passou é o mais complicado, é o mais complexo, a construção de um contexto histórico, de uma continuidade, de uma permanência, de uma consequência, essa é a maior dificuldade e é a maior preocupação, construir isso neles.

$\mathrm{P}$ - Até que ponto você considera que os seus alunos te escutam em quais ocasiões e em que outras, isso não acontece?

$\mathrm{R}$ - Olha, aqui, nessa... já tive outras experiências que foram muito ótimas, sabe assim, de no momento de estar na sala de aula, os caras: "Não quero, não vou, não faço" e ao longo dos anos, ao logo do processo numa mesma escola, depois de alguns anos, eu saí dessa escola, como eu disse, sou cigana, né, e aí, eu tive contato com uma outra professora, eu soube que esses alunos... eu dei aula para eles... um exemplo, né, no sétimo ano e depois, essa professora continuou com ele numa outra escola e eles se formaram no terceiro ano do Ensino Médio e eles me citaram na formatura como alguém que tinha feito... fez com que eles estudassem, então assim, naquele momento em que eu estava na sala de aula, foi terrível, foi frustrante, foi muito sofrido, mas no processo de amadurecimento desses alunos, eles entenderam aquilo que eu falei. Então assim, às vezes, você tá na sala de aula e nada funciona, mas é um processo de construção mesmo. Já tive outros momentos em que os alunos estavam extremamente interessados, extremamente participativos. Aqui, infelizmente, pelo fato de eu ter entrado na metade do ano, a professora era muito querida, estava com eles há muitos anos, então, esse vínculo, ele tá começando a se construir, então, prestar atenção na aula é muito difícil, fazer as atividades é muito difícil, tem sido um pouco complicado. Mas em outros momentos, já foi mais fácil. Então, depende do contexto mesmo, da situação. 
$\mathrm{P}$ - O que você nomearia como a maior dificuldade de um professor do Ensino Fundamental, hoje?

R - São tantas dificuldades... eu acho que é o interesse do aluno, honestamente, eu estava conversando até ontem com uma amiga... nem sei se deveria falar isso, mas... eu acho que a escola, ela... essa questão da universalização do ensino, sabe? Não é que o aluno não mereça ter acesso à educação, não é isso, mas nem todos os alunos querem estar dentro da sala de aula, nem todos os alunos têm essa vocação para estar dentro da sala de aula. Eu acho que a escola, ela precisa existir para aqueles que querem estudar. Deveria ter um outro mecanismo para atender esses outros alunos que não querem. Por exemplo, quando eu estudava, tinham vários alunos que não queriam, eles iam para o Paula Souza, né, que eram as escolas técnicas e ali, eles tinham outras atividades e eram felizes, eram bem sucedidos, funcionava. Eu, depois, quando eu fui... que eu me formei, eu fui fazer um estágio, inclusive numa dessas escolas, a aula fluía muito bem, né, os alunos participavam porque depois, eles sabiam que eles iam para a aula prática e que aquilo tinha sentido, significado para a vida deles, o que hoje... o que eu percebo hoje é que esses alunos não conseguem ver significado, não faz sentido da realidade que eles vivem para dentro de uma sala de aula, tendo que estudar o século XII, a formação do Império Carolíngio, sei lá, não entra na cabeça dele, porque a realidade dele é completamente diferente. Então, a maior dificuldade é essa, você dar sentido para o cara dentro da escola, né, criar um significado para ele e infelizmente, não tem. E isso prejudica aquele que quer estar aqui, que quer aprender, que se dedica, sabe?

$\mathrm{P}$ - De que maneira você acha que os alunos veem você?

$\mathrm{R}$ - Neste momento eu tenho recebido muitos elogios: bruxa (risos), de uma forma não muito... agora, agora, eles têm... eles me acham exigente, pronto! É isso. Não que os outros não sejam, por favor, não é isso que eu estou dizendo... exigente no sentido de que eu fico pegando no pé, eu quero que eles prestem atenção, então nesse sentido, eu sou exigente, mas não significa que eu sou ótima, pelo contrário, é chatice mesmo pra eles.

$\mathrm{P}$ - Tá bom. Mais alguma coisa que você queira comentar?

$\mathrm{R}$ - Acho que é isso ai.

P - Tá bom. Obrigada.

$\mathrm{R}$ - Boa sorte. 
$\mathrm{P}$ - Obrigada.

\section{Maria -Professora do Ensino Fundamental I}

$\mathrm{P}$ - Primeiro, eu quero saber a sua idade.

$\mathrm{R}-$ Eu tenho 30 anos.

$\mathrm{P}$ - O local onde você nasceu?

R - Em São Paulo, mesmo.

$\mathrm{P}$ - Onde você viveu a maior parte?

R - São Paulo.

P - Em São Paulo, também?

$\mathrm{R}-\mathrm{E}$.

$\mathrm{P}$ - Sua formação?

$\mathrm{R}$ - Eu sou formada em Educação Física, licenciada plena.

$\mathrm{P}$ - E há quanto tempo você é professora?

R - Eu acho que há uns sete anos. Sete anos, eu me formei em 2007, sete anos.

$\mathrm{P}$ - Como que era na sua família, a abertura para falar e conversar?

$\mathrm{R}$ - Depende do assunto. Depende do assunto. Mas era tranquilo, tinha uma boa via de comunicação, mas não em todos os assuntos.

$\mathrm{P}$ - Qual que era o espaço que as crianças tinham para falar? Como criança, como é que você via isso?

$\mathrm{R}$ - Então, eu acho que lá na minha casa sempre foi tranquilo assim, mas é aquela questão assim: “A última palavra é sempre dos pais”, tudo, mas a gente tinha um bom espaço, sim.

P - Legal. E como era tratada a autoridade dos adultos sobre as crianças na sua infância? Que é isso que você acabou de falar... 
$\mathrm{R}$ - Então, é essa questão de: "Você é criança, você pode, mas a última palavra é a do papai, é a da mamãe, era dos pais, nós somos os responsáveis, quando você fizer 18 anos, aí você pode decidir, mas enquanto você não tem 18 anos, somos nós”, aí eu ficava: “Ai, meu Deus, chega $\log 018 "$ (risos).

$\mathrm{P}$ - Pediam a sua opinião para alguma coisa?

R - Não. Não. Eram sempre eles que decidiam, por mais que a gente falasse: "Ah mãe, mas eu não gosto disso, eu não quero" "Mas eu gosto e eu quero, vai ser assim".

$\mathrm{P}$ - Tá bom. Agora, eu vou perguntar um pouco sobre a prática pedagógica. Se você comparar suas ações, sua rotina de sala de aula com a de muitos anos atrás, você percebe alguma mudança da relação dos alunos com a sua palavra?

$\mathrm{R}$ - Mais ou menos. É porque eu pego várias turmas, né, e são vários perfis diferentes, os pequenininhos, os grandes. Eu não percebo tanta mudança, não. Eu vejo uma mudança de atitudes deles em relação ao todo. Agora, em relação a mim, ao que eu tô falando, ao que eu tô combinando: "O combinado da aula é esse", não vejo tanta diferença.

$\mathrm{P}$ - E qual seria em relação ao todo?

$\mathrm{R}$ - Assim, ixi, eu já até esqueci o quê que eu falei (risos)

$\mathrm{P}$ - Não, mas relaxa, não tem problema.

$\mathrm{R}$ - Não, eu não vejo muita mudança no que eu falo da minha prática, do que eu faço, eu não vejo muita mudança. Eu vejo mudança do comportamento do todo assim, em todas as disciplinas, como eles encaram os assuntos, mas em relação ao que eu tô falando da aula: "Hoje, nosso combinado é que a gente vai fazer tal aula e não pode fazer isso, vamos fazer isso", os combinados continuam, eles agem da mesma maneira, mas a atitude fora de sala de aula, de outras coisas, eu vejo uma mudança deles, mas dos meus comandos, do que eu faço, não, agora, de cotidiano, de outras coisas que eles fazem, saiu da escola e vou fazer determinada coisa, eu vejo mudança...

$\mathrm{P}$ - Mas como assim essa mudança?

$\mathrm{R}$ - De comportamento. De comportamento, conforme vai passando as turmas que eu vou pegando, eu vejo que não tem mais um perfil de algumas coisas que eles faziam, tipo, se eles brincam, algumas crianças que brincavam mais quando saíam daqui, hoje eu não vejo tanto. 
$\mathrm{P}-$ Entendi.

$\mathrm{R}$ - Entendeu? Agora, do meu comando, do que eu falo, da minha linha de comunicação com eles dentro de sala, eu não veja tanta diferença, porque é sempre o mesmo... não que seja sempre o mesmo combinado, mas a gente sempre tenta manter aquela linha. Então, eles já conhecem, mais ou menos, principalmente aqui, que eu já tô um pouquinho mais de tempo. Então eles: “Ah, não”, então a gente consegue se entender.

$\mathrm{P}$ - Há sete anos você tá trabalhando aqui?

R - Não. Sete anos na educação, tem três que eu trabalho aqui. Então, aí eles já sabem: “A professora Juliana, ela faz isso, ela faz assim”, aí eles já sabem mais ou menos, já conseguem saber o perfil, mas eu vejo uma mudança em relação a outras coisas, né, como isso, essa atitude de não brincar ou de desde cedo já está namorando, ou alguma coisa assim. Essas coisas assim.

P - Tá, legal. Quando você, professora está ministrando aulas, quais são as suas maiores preocupações com o que ou com o que você tá falando?

$\mathrm{R}$ - Que eles compreendam o real objetivo do que eu tô fazendo, porque, o significado do que vai ser feito, né? Então, eu vou passar determinada brincadeira ou determinado jogo ou até uma aula teórica, o porquê, que eles compreendam, que eles consigam entender a minha linguagem e porquê que aquilo está sendo feito, qual é a importância. Essa é... no primeiro momento, é essa a minha preocupação.

$\mathrm{P}-\mathrm{E}$ até que ponto você considera que os seus alunos te escutam?

$\mathrm{R}$ - Olha...

$P$ - Em quais ocasiões e em quais outras, isso não acontece?

$\mathrm{R}$ - Na maior parte, desde que eu comecei a trabalhar na educação escolar, o educador físico, ele pega todas as séries, né? Fundamental 1, Fundamental 2, Ensino Médio, então assim, todos, independente da idade, eles te ouvem na maior parte... assim, a princípio, desde que seja feito o que eles querem: "Eu vou escutar, porque senão, eu não vou descer para quadra", "Eu vou obedecer, porque senão, não tenho a aula prática", então, a princípio, o primeiro momento é esse. Aí, eu vou escutar, né? Mas depois, a gente desenvolve, mas no começo é assim. 
$\mathrm{P}$ - Ah, legal. O que você nomearia como a maior dificuldade de um professor do Ensino Fundamental, hoje?

$\mathrm{R}-\mathrm{Eu}$ acho que é exatamente isso. Talvez que ele te escute e entenda, né, que ele pare pra te ouvir que é algo importante, que é algo bacana, que ele valorize o que você tem para passar e que ele consiga aprender, como ele aprende? Como que eu vou conseguir atingir? Às vezes, ele não quer ouvir, como que eu vou atingir esse aluno que ele precisa aprender o que é realmente importante? Então, eu acho que esse é um desafio, como aprende e como escuta.

$\mathrm{P}$ - De que maneira você acha que os alunos veem você?

$\mathrm{R}$ - Complicado, porque o professor de Educação Física na escola, ele sempre encara todos da mesma maneira: "Ah, a gente vai pra quadra, que... não sei o que... vamos brincar, aula livre”. Eu acabei conquistando um espaço aqui dentro, assim, eles já me encaram... no começo, era assim: "Eeee, Educação Física, vamos descer, vamos brincar!”, agora não, eles já sabem: "Hoje é aula na sala? Hoje é aula teórica ou é prática? A gente vai escrever? A gente vai ler?", então assim, eu vejo que eles já encaram com um pouquinho mais de importância, não só uma aula recreativa, eles estão começando essa conscientização, tá pouquinho, ainda, passinho... trabalhinho de formiguinha, mas eu acho que já é um avanço.

$\mathrm{P}$ - Tá bom. Tem mais alguma coisa que você quer falar?

R - Não.

P - Não? Tá bom. Obrigada.

$\mathrm{R}$ - Nada. Imagina!

\section{Gustavo -Professor do Ensino Fundamental II}

$\mathrm{P}$ - Sua idade?

$\mathrm{R}$ - Trinta e cinco anos.

$\mathrm{P}$ - Local onde você nasceu?

R - Maringá, Paraná.

$\mathrm{P}-\mathrm{E}$ onde você viveu a maior parte? 
$\mathrm{R}$ - A maior parte eu vivi em Maringá, mas eu morei em várias cidades já, eu morei em nove cidades.

$\mathrm{P}$ - Você quer falar?

R - Morei em várias cidades do Paraná, por exemplo, Apucarana, Arapongas. Cascavel, Paranavaí e morei em São Paulo capital e Araçatuba, também no interior de São Paulo.

$\mathrm{P}-\mathrm{E}$ o local em que viveu a maior parte?

$\mathrm{R}$ - A maior parte eu vivi em Maringá.

$\mathrm{P}$ - Formação?

R - Eu sou formado em Geografia, licenciatura e tenho pós-graduação em Ensino de História e Geografia.

$\mathrm{P}$ - Legal. Há quanto tempo é professor?

$\mathrm{R}$ - Sou professor há dez anos.

$\mathrm{P}$ - Como que era na sua família, a abertura para falar e conversar?

$\mathrm{R}$ - A gente sempre teve abertura, assim, sempre conversamos, meus pais sempre foram mais atentos ao que a gente fazia ou não e sempre deram liberdade pra gente conversar. Acho que com os homens isso era mais tranquilo, que eu tenho irmã. Então, com a minha irmã já era um pouco mais... a abertura já não era tão grande. Então, a minha mãe conversava mais com ela do que o meu pai.

$\mathrm{P}$ - Qual que era o espaço que as crianças tinham para falar?

$\mathrm{R}$ - Era pouco. Na verdade, a gente tinha medo, porque nós tínhamos muitas sanções contra algumas atitudes que a gente fazia. $\mathrm{Eu}$, como sempre estudei em colégio católico e a disciplina é muito forte, então, a gente não podia na verdade, ficar falando muito. Tinha que mais obedecer e havia sempre um medo pelo o que poderia acontecer se a gente não obedecesse.

P - Como era tratada a autoridade dos adultos sobre as crianças na sua infância?

$\mathrm{R}$ - Os adultos, eles tinham os mecanismos, então por exemplo, aquele livro negro, tinha a suspenção, tinha aquela coisa de tirar o aluno da sala de aula, tomava uma bronca ou ia direto 
para sala do diretor, o diretor conversava com a gente e ai, tinham diretores que mais se preocupavam em brigar e outros tentavam entender o que estava acontecendo, mas a maioria queria mesmo era... assim, eles ouviam a nossa parte, mas na verdade, eles queriam aplicar mesmo a punição que servisse de exemplo pros outros, que eles não fizessem.

P - Agora sim, para prática pedagógica. Se você comparar as suas ações, sua rotina de sala de aula com a de muitos anos atrás, você percebe alguma mudança na reação dos alunos com a sua palavra? E quais seriam?

$\mathrm{R}$ - Eu acho que mudou um pouco, porque assim, os alunos ouviam um pouco mais antes. Hoje, eu tenho... a maioria me ouve, mas eu tenho um número maior de pessoas que não ouvem. E aí, por vários motivos, ou porque não se concentram, ou porque estão preocupados só em brincar ou porque às vezes, eles não entenderam a proposta do estudo e aí, acaba brincando. Então, a gente acaba perdendo um pouco esses alunos por essas questões e muitas vezes, eles não falam, porque que eles estão daquele jeito, não sabem dizer porquê. Então, eu vejo que essa relação da disputa, ela mudou um pouco. Hoje, eles têm o nível de atenção, o tempo que eles ficam atentos a gente é muito menor, a gente consegue mantê-los atentos por cinco minutos ouvindo. $\mathrm{O}$ restante tem que ser com atividades práticas, senão eles dispersam.

$\mathrm{P}-\mathrm{E}$ antes, como é que era?

$\mathrm{R}$ - Antes, a gente tinha mais concentração assim, até porque as aulas eram muito expositivas, a gente tinha que ter atenção a essas aulas, tinha muita leitura também e eu acho, na minha época, eu acredito que nós éramos mais atentos, até porque tinha uma questão também da repreensão se a gente não ficasse atento às aulas. Hoje em dia, talvez por uma liberdade maior ou porque tem uma coisa do imediatismo atualmente, que as pessoas querem as coisas pra hoje, agora. Eu acho que um pouco a mídia é culpada disso, então, essas crianças que estão vindo agora também, que eu acho que é reflexo dos pais, que mudaram um pouco a cabeça, eles querem tudo pra já, pra agora. Então, eles são crianças muito ansiosas e que não sabem esperar, não sabem se concentrar, ler um comando para poder saber o que tem que fazer, eles já querem sair fazendo e muitas vezes, eles nem sabem o que estão fazendo.

P - Quando você tá ministrando aula, quais são as suas maiores preocupações com o que e com quem você tá falando?

$\mathrm{R}$ - Assim, quando eu tô ministrando aula, eu não gosto de conversas paralelas, porque muitas vezes, eles falam de coisas que não têm nada a ver com o assunto e eles não conseguem se 
concentrar. E às vezes, eu me preocupo também com aqueles alunos que às vezes, tem alguma dificuldade de leitura, de escrita e como ele não tá entendendo exatamente o que tá acontecendo naquele momento, ele começa a conversar com o colega do lado e isso acaba dispersando muita gente. Então, essas são as minhas duas maiores preocupações, assim.

$\mathrm{P}$ - Até que ponto você considera que seus alunos te escutam, em quais ocasiões? E em que outras, isso não acontece?

$\mathrm{R}$ - Eles escutam assim, como eu falei antes, quando eu tenho que dar o comando da atividade, eu consigo manter uma certa atenção deles, só que eu não posso ficar falando muito. As minhas aulas, antes, eram... o tempo de aula expositiva era maior, depois eu fui aprendendo outras práticas, outras formas de ministrar um conteúdo com outros tipos de atividades que eu não preciso ficar falando e que eu acho que muitas vezes, é mais eficiente, só que muitas vezes, eles não escutam quando a proposta, às vezes, não interessa pra eles, eles acham que aquilo não vai ser legal ou pela dificuldade de alguns alunos. Alguns não conseguem, por exemplo, ler ou escrever corretamente, então, eles se dispersam, porque justamente, eles sabem que eles não vão conseguir. Porém mesmo sabendo que, às vezes, a gente tem uma ajuda, eu dou uma ajuda para eles nesse sentido, eu sento com cada um deles, procuro fazer, na hora da explicação para eles, não interessa. Então, eles acabam distraindo várias pessoas da turma, acabam incomodando, às vezes, porque você tá falando, explicando o que eles vão fazer e uma pessoa fala junto com você. Então, essa é a maior dificuldade que eu vejo.

$\mathrm{P}$ - O que você nomearia como a maior dificuldade do professor do Ensino Fundamental, hoje?

$\mathrm{R}$ - Olha, pra mim, eu aprendi assim, ao longo dos meus estudos, várias práticas de trabalho que foram dando certo. Eu acho que são práticas que se tornaram muito mais interessantes. Se eu pegar o meu começo de carreira até hoje, eu vejo que as minhas aulas melhoraram. Mas hoje, a maior dificuldade é lidar com a falta de respeito dos alunos. Assim, os alunos, eles, muitas vezes, trazem das suas casas o jeito deles lidarem com as suas famílias, então assim, eles respondem muito, eles debocham. Então, tem muito aluno que não te obedece, que quer te enfrentar, porque ele tá vendo na frente dele uma autoridade, não o professor. Então, talvez, ele tenha uma situação assim, de que ele não tem abertura para falar, ele briga com isso em casa e ele chega aqui, ele quer fazer a mesma coisa. Pra mim, a maior dificuldade não é nem 
pedagógica, eu acho que nisso, eu consigo me resolver, o problema é a falta de respeito, mesmo.

$\mathrm{P}$ - E você acha que eles veem os professores como uma autoridade?

$\mathrm{R}$ - Ainda veem. Eles não veem a gente como uma pessoa que tá ali para tentar ensinar alguma coisa para a vida deles. Eu acho que eles veem a gente como autoridade que tenta manter um controle. Eles ficam tentando... muitos tentam desafiar essa autoridade, mesmo às vezes, sem um motivo real. Então por mais... tem gente que não sabe lidar com a abertura para o diálogo, então eles acham que isso é perda de tempo, não é aula. E se você, por exemplo, dá aula de fato, alguns também reclamam, porque você tá dando aula. Na verdade, eles querem não fazer nada muitas vezes. Então, você tem que lidar com esses dois extremos, os dois lados da mesma moeda.

$\mathrm{P}$ - De que maneira você acha que os alunos veem você?

$\mathrm{R}$ - Então, eu acho que a maioria me vê como... assim, alguns me veem como o pai que não têm, alguns me veem como um amigo, que eles precisam contar coisas. Alguns me veem como o professor que realmente tá ensinando alguma coisa que tá fazendo diferença para eles quando eles saem, voltam e conversam: "Olha, aquilo que você me ensinou, eu aprendi em tal lugar e eu vi novamente, e consegui me dar muito bem nisso". Eu acho que eles me veem como várias coisas, mas como professor de verdade, acho que a minoria é que vê, entendeu? Até pelas relações familiares de hoje em dia por serem muito diferentes, então eu acabo sendo um pouco de tudo: ou o pai, ou a mãe, ou o amigo e talvez, lá embaixo, eu sou o professor deles (risos).

P - Tá bom. Você quer falar mais alguma coisa?

$\mathrm{R}$ - Não, acho que é isso. O que realmente assim, eu sempre procuro estudar para tentar melhorar a prática, tentar dar um sentido... no caso, eu sou professor de Geografia e também de História, eu procuro sempre práticas para tentar adequar o momento atual que a gente vive com os estudos que eles têm, para dar um sentido, na verdade para o que eles estudam, né, o que que aquilo vai fazer de diferença na vida dele, não só ficar estudando conteúdo por estudar e também aprender algumas habilidades. Mas as dificuldades são essas, a gente tem essa dificuldade do imediatismo deles, para que que isso serve, vou usar quando isso na minha vida. Então, eles querem umas coisas muito pra já e a própria relação de respeito, ela é 
muito afetada. Então, os professores, eles não são... eu não digo que é só culpa deles, eu acho que tem uma parte sim, que é dos alunos, das relações familiares, tem uma parte, às vezes, dos professores, que também não dão o devido respeito, no sentido, por exemplo, a pessoa não planeja uma aula. A pessoa não olha com um pouco mais de atenção certos alunos que precisam e eles percebem isso. Então, por outro lado, tem também o comportamento do professor que não dá muita razão, muito sentido para o que faz e automaticamente, o aluno, ele acaba devolvendo, também, com aquela postura dele de que ele não quer fazer, que ele tá desinteressado. Mas eu acho que primeiro, parte da gente. Depois, a outra parte é ver então, porque que o aluno, ele não consegue se manter concentrado, porquê que ele é desrespeitoso com o outro. Enfim, acho que é isso.

P - Tá ótimo. Obrigadão.

$\mathrm{R}$ - Imagina.

\section{Felipe -Professor do Ensino Fundamental I e II}

$\mathrm{P}$ - Sua idade?

$\mathrm{R}$ - Trinta e cinco.

$\mathrm{P}-\mathrm{O}$ local onde nasceu?

$\mathrm{R}$ - São Paulo.

$\mathrm{P}$ - Local onde viveu a maior parte?

R - São Paulo.

P - Formação?

R - Formação aí, entra o que, assim? Graduação em Educação Física?

$\mathrm{P}-\mathrm{E}$, qual é a sua formação?

R - Graduação em Educação Física.

$\mathrm{P}$ - Há quanto tempo é professor?

R - 2000, 2001... dá... 14 anos. 
$\mathrm{P}$ - Como que era na sua família, a abertura para falar e conversar? Na sua família.

$\mathrm{R}$ - Qualquer assunto ou de...

$\mathrm{P}-\mathrm{E}$, se tinha abertura para qualquer assunto, ou se era mais difícil, ou ninguém conversava muito?

$\mathrm{R}$ - Lá em casa, sempre os meus pais foram mais... o meu pai, né, mais quieto, a gente nunca foi de falar tudo assim, mas acho que é pessoal, mas eles perguntavam, né, eles vinham questionar ou perguntavam, mas eu e os meus irmãos sempre fomos muito reservados assim, a gente não abria muito o jogo. Mas era aberto, eles perguntavam, tal, tinha essa liberdade.

$\mathrm{P}$ - Qual que era o espaço que as crianças tinham para falar?

$\mathrm{R}$ - Na minha família?

P - Sim. Você como criança.

$\mathrm{R}$ - Então, tinha. Tinha sim, a gente quando tinha um problema ou uma coisa para solucionar, a gente tinha espaço para argumentar, sentávamos para conversar, quando o espaço era individual, com um só ou sentava todo mundo para tentar resolver. Então... mas acho que é de personalidade, dificilmente, uma criança levava o problema, era sempre o pai que viu algum problema e trazia, sabe?

$\mathrm{P}$ - Entendi. Como era tratada a autoridade dos adultos sobre as crianças na sua infância? $\mathrm{R}$ - Como era tratada? Minha mãe sempre foi assim, muito rígida nesse sentido, que o adulto... ela dava sempre mais razão ao adulto do que a criança, quando fala, né, que o adulto sempre tinha razão porque tinha uma visão um pouco mais ampla do acontecido do que a criança. Então, ela sempre valorizava mais a visão de um adulto do que de uma criança.

P - Agora sobre a prática pedagógica. Se você comparar suas ações, sua rotina de sala de aula com a de muitos anos atrás, você percebe alguma mudança da relação dos alunos com a sua palavra? E quais seriam?

$\mathrm{R}$ - Tá. Vamos lá, que eu perdi um pedaço. Se eu comparar as minhas ações...

$\mathrm{P}$ - De hoje com as de muitos anos, quando você começou a dar aula. Tem alguma diferença da relação deles com a sua palavra? 
$\mathrm{R}$ - Tem. Eu acho que assim, o que eu mais sinto que mudou é como eu trato os assuntos. Como eu, não... e como eu falo com os alunos pra gente resolver. Então, como eu trato o assunto que mudou. Eu acho que para os alunos, mesmo no início, eu conseguia resolver, mas hoje é mais natural, dificilmente uma coisa que nunca me aconteceu antes, então pra mim, é mais tranquilo. Já no começo, você fica meio inseguro, age de uma maneira e aí, depois, você reflete: 'próxima vez, vou fazer assim, vou fazer assim', então, como eu vejo os problemas que acho que mudou, né?

P - Quando você, professor está ministrando aulas, quais são as suas maiores preocupações com o que ou com quem você tá falando?

$\mathrm{R}$ - Assim, eu me preocupo muito primeiro com o espaço que eu vou dar aula: onde é, se o espaço tá adequado, tem quadra que às vezes, a grade tá pontuda, ou se tem pedra... essas coisas. Então, a primeira coisa, eu me preocupo com o espaço. Depois, se o material ou a atividade é adequada para aquilo, se eu vou conseguir trabalhar o maior número de alunos possível, criar interesse no maior número de alunos possível. Então, é com isso que eu me preocupo, se vai ter o maior número de alunos possível e se o espaço não oferece risco para ninguém se machucar.

$\mathrm{P}$ - E qual a sua preocupação com o que você tá falando para eles?

$\mathrm{R}-\mathrm{O}$ que é pertinente, assim?

P - Quando você tá conversando com eles, quais são as suas preocupações, assim, que passam na sua cabeça?

$\mathrm{R}$ - Depende, né, depende assim, muito da turma, porque tem turma que às vezes, eu tenho que falar, pensar na atividade, porque tem, sei lá, um lado que eles já levam pejorativo muito escrachado, tudo... agora, eu me preocupo assim, se eles estão prestando atenção, se aquilo tem a ver, se o que eu tô falando faz sentido para eles, não faz sentido, se eles têm uma bagagem para entender aquilo, ou se não tem. Se eu tenho que falar coisas mais pra trás ou mais pra frente, se tá muito fácil, essas coisas.

P - Até que ponto você considera que os seus alunos te escutam? Em quais ocasiões e em quais outras, isso não acontece?

$\mathrm{R}$ - Então, aí eu já penso assim, que eu não sei se eu já desestimulei, mas assim, nunca espero $100 \%$, já é uma coisa que até se você parar para pensar, desanima, porque... mas não espero 
que $100 \%$ eles me escutem. Assim, tem uns que conhecendo, que só de ficar quieto, você já fica feliz, sabe? "Esse tá quieto, então tá bom”. Mas assim, como eu falei, pra mim é assim, se tá desinteressante, é porque ou tá muito fácil ou tá muito longe do que eles conseguiriam ver, imaginar ou fazer, né? Então, me preocupo se a maioria, eu penso sempre na maioria, se faz sentido para a maioria, porque tem aluno que às vezes, tá mais preocupado com problema de casa que tem, sei lá, pai e mãe e não tá nem olhando para você, então, penso sempre na maioria. Eu penso só o que vai ficar para a maioria.

$\mathrm{P}$ - O que você nomearia como a maior dificuldade de um professor do Ensino Fundamental, hoje?

R - Maior dificuldade? É a falta de educação dos alunos. Falta de respeito, assim, de interesse. Eles não conseguem ver um sentido em estudar, os objetivos que eles têm para a vida deles não entra a educação, então é difícil nisso, porque você fala, mas eles não conseguem imaginar que aquilo vai servir para a vida deles, então não têm o menor interesse, talvez porque os pais não cobrem, não perguntem: “O que foi que você fez hoje?”, "O que que teve hoje?" Sabe? Aquilo não tem um sentido pra eles, né, parece que não faz sentido.

$\mathrm{P}$ - E você acha que você tem autoridade na sala de aula, como professor?

$\mathrm{R}$ - Tenho. Eu acho que eu sou respeitado. Eles respeitam e não têm medo, isso que eu sempre falo para eles: "Não quero que ninguém tenha medo de mim, eu quero que tenha respeito", então, isso eu acho que eu tenho, sim.

$\mathrm{P}-\mathrm{E}$ de que maneira você acha que os alunos veem você?

$\mathrm{R}$ - É assim, muda muito eu acho, quem não me conhece, é a primeira vez que está tendo aula comigo, eu acho que me vê bem chato, porque eu cobro muita coisa. Dou aula teórica de Educação Física, então já acham tudo muito chato, mas aí, com o passar do tempo, eu acho que vou conseguindo ligar a teoria com a prática e aí eles vão dando mais valor. Daí, o que é legal até ex-alunos vêm falar: “A minha aula na outra escola é assim, não era assim”, então, eu acho que dá mais valor com o passar do tempo. Acho que no começo, eles me veem bem chato, exigente, assim.

$\mathrm{P}$ - Depois, você se sente mais próximo? 
$\mathrm{R}$ - Depois eu me sinto mais próximo. Sempre começa assim, começo do ano bem distante, muita briga, muitos atritos e aí depois, eu vou conhecendo melhor eles, eles vão me conhecendo, aí vai ficando mais fácil para trabalhar.

P - Beleza. É só isso, então. Obrigada. Fácil, vai?

R - Não, não, tranquilo.

\section{Manuela -Professora do Ensino Fundamental I e II}

$\mathrm{P}-\mathrm{A}$ sua idade?

$\mathrm{R}$ - Vinte e oito anos.

$\mathrm{P}$ - Local onde você nasceu?

R - Em São Paulo.

$\mathrm{P}$ - Onde você viveu a maior parte?

$\mathrm{R}$ - Eu mudei muito, eu vivi uma parte na Zona Norte de São Paulo, depois no bairro do Jaraguá e aí, agora, em Osasco.

P - Tá. Formação?

$\mathrm{R}$ - Eu sou formada em Geografia

P - Há quanto tempo é professora?

$\mathrm{R}$ - Vai completar três anos, dois anos e meio.

$\mathrm{P}$ - Como que era na sua família, a abertura para falar e conversar?

$\mathrm{R}$ - Normal. Nunca teve tabu sobre alguma coisa, sempre foi aberta a conversa.

$\mathrm{P}$ - Qual que era o espaço que as crianças tinham para falar?

$\mathrm{R}$ - Olha, eu acho que poderia ter sido melhor, né, o espaço para falar sobre... você diz assim sobre vontade? Sobre...

$\mathrm{P}-\mathrm{E}$, qualquer coisa. $\mathrm{O}$ espaço que tinha assim. 
$\mathrm{R}$ - Eu acho que poderia ter sido melhor, mas no geral, foi uma coisa... assim, meus pais nunca foram pais que, sabe, batem em criança, a gente nunca apanhou, eu tenho mais um irmão então, a gente nunca sofreu nenhum tipo de repressão assim, mas acho que a gente poderia ser melhor em comunicação, mesmo.

P - Como era tratada a autoridade dos adultos sobre as crianças na sua infância?

$\mathrm{R}$ - Era uma questão de respeito, né, a gente chamava pai de "senhor", mãe de "senhora". O que eles falavam, a gente fazia. É bem diferente do que hoje em dia a gente vê, né, as crianças já passam por cima das vontades dos pais.

P - Agora sobre a sua prática. Se você comparar suas ações, sua rotina de sala de aula com a de muitos anos atrás, você percebe alguma mudança da relação dos alunos com a sua palavra? E quais seriam?

$\mathrm{R}$ - Sim. Essa questão da autoridade dos pais, eu acho que acontece a mesma coisa com os professores. O professor na sala de aula, ele não tem mais autoridade, as crianças... e eu nem sei se é uma culpa das crianças, é porque muita coisa mudou, né, existe uma coisa... sei lá, muita coisa diferente hoje em dia. Mas enfim, alguns professores ainda insistem em tratar o aluno dessa forma, com autoridade total. Eu acho que isso é uma coisa errada e tem alunos que também não têm o mínimo respeito nem por aquele professor que trata ele bem, que... existe aí, acho que é uma decadência, não sei para onde é que vai...

$\mathrm{P}$ - Você acha que é do professor mesmo, ou é de alguma outra coisa?

R - Não, não é só do professor. É a relação familiar, você não fez essas questões sobre a família, né, na minha época? Hoje em dia, a gente tem relatos, por exemplo, da comunidade aqui de crianças... de mãe que tá às três horas da manhã na rua, fumando ou bebendo e o seu filho do lado. Então, eles têm uma estrutura familiar muito diferente, muito... eu não sei a que se deve isso, se os pais são jovens demais ou se são inconsequentes demais, mas a relação deles hoje em dia é outra e também, tem professor, não são todos, tem um ou outro professor que não acompanhou isso, que ainda acha que deve ser como na época da palmatória, que o aluno tem que sentar em fileirinhas, ficar em silêncio, baixar a cabeça e não é assim, né? A gente tem que acompanhar as mudanças do nosso tempo.

P - Quando você está ministrando aulas, quais são as suas maiores preocupações com o que ou com quem você tá falando? 
$\mathrm{R}$ - Eu fico preocupada em me fazer entender, que às vezes, eu acho que talvez eles não compreendam a forma que eu estou falando e fico muito preocupada em sala de aula também, da quantidade de alunos que tem, porque são muitos alunos pra um professor só, às vezes, a gente entra em dois dentro da sala de aula, mas a qualquer momento, eu fico meio pirada, não sei se é real isso, a qualquer momento, eles podem sei lá, fazer alguma coisa... agredir um outro aluno, como já aconteceu muitas vezes, dentro da minha sala de aula, um aluno jogou a cadeira na cabeça de um outro aluno e eu não pude fazer nada porque eu estava longe. Então, eu tenho essa preocupação também com a quantidade de alunos em sala de aula e eles saírem do controle, porque é um espaço muito pequeno para eles, essa sala de aula.

$\mathrm{P}$ - Até que ponto você considera que os seus alunos te escutam? Em quais ocasiões e em que outras, isso não acontece?

$\mathrm{R}$ - Olha, eles me escutam mais quando o assunto é algo de muito interesse pra eles, né, para falar sobre música, sobre os jogos, sobre celulares, sobre... enfim, coisas que são pertinentes ao universo deles. Só que na escola, a gente não consegue tratar só disso, né, a gente é cobrado do conteúdo, da disciplina, da matéria... quando a gente vai falar sobre esse conteúdo, aí eles se tornam apáticos. Você tá aqui na frente, olha para sala de aula e não tem ninguém olhando pra você, você tá falando só com as paredes.

$\mathrm{P}$ - O que você nomearia como a maior dificuldade de um professor do Ensino Fundamental, hoje?

$\mathrm{R}$ - São várias, mas eu acho que a maior mesmo é essa questão da quantidade de alunos em sala de aula. Muitos alunos para um professor só.

$\mathrm{P}$ - Você acha que isso dificulta deles te escutarem?

$\mathrm{R}$ - Dificulta. Dificulta, porque são muitos, né, eles ficam... são muitos e o mundo é muito interessante, são de 35 para mais, mas o máximo permitido por lei, acho que são 35. E aí, eles têm as histórias, eles contam fofocas, eles têm " $n$ " conversas, " $n$ " coisas para falar e terminam não escutando o professor

$\mathrm{P}$ - De que maneira você acha que os alunos veem você?

$\mathrm{R}$ - Olha, essa é uma pergunta bem difícil, eu tento ser com eles o mais humana possível. Assim como a gente, eles também têm uma série de problemas, os alunos dessa escola principalmente, que são ali da comunidade é cada história para contar que dá um livro: de 
abandono, de aluno que viu o pai ser assassinado, de abuso. Então, eu tento ser com eles o mais humana possível para que eles me vejam dessa forma, mas eu também acho que não atinge $100 \%$ dos alunos, alguns devem me ver como uma bruxa, alguma coisa assim, alguém que está para impor disciplina, sei lá.

$\mathrm{P}$ - Tem mais alguma coisa que você queira falar?

$\mathrm{R}$ - Não, acho que... 